Universidade de Brasília

Instituto de Ciências Sociais

Centro de Pesquisa e Pós-Graduação sobre as Américas

Programa de Pós-graduação em Estudos Comparados sobre as Américas

\title{
A TOMADA DE DECISÃO NAS RUAS: UM ESTUDO COMPARATIVO ENTRE A ATUAÇÃO DA POLÍCIA NO BRASIL E NA COLÔMBIA
}

Verônica Almeida dos Anjos

Brasília

Março de 2016 
Universidade de Brasília

Instituto de Ciências Sociais

Centro de Pesquisa e Pós-Graduação sobre as Américas

Programa de Pós-graduação em Estudos Comparados sobre as Américas

\section{A TOMADA DE DECISÃO NAS RUAS: UM ESTUDO COMPARATIVO ENTRE A ATUAÇÃO DA POLÍCIA NO BRASIL E NA COLÔMBIA}

Tese apresentada ao Programa de Pós-Graduação em Estudos Comparados sobre as Américas do Centro de Pesquisa e Pós-Graduação sobre as Américas como requisito à obtenção do título de Doutor (a) em Ciências Sociais.

Verônica Almeida dos Anjos

Brasília

Março de 2016 
Universidade de Brasília

Instituto de Ciências Sociais

Centro de Pesquisa e Pós-Graduação sobre as Américas

Programa de Pós-graduação em Estudos Comparados sobre as Américas

\title{
A TOMADA DE DECISÃO NAS RUAS: UM ESTUDO COMPARATIVO ENTRE A ATUAÇÃO DA POLÍCIA NO BRASIL E NA COLÔMBIA
}

\author{
Verônica Almeida dos Anjos
}

Orientador: Prof ${ }^{a}$. Dr ${ }^{\mathrm{a}}$. Rebecca Lemos Igreja

Banca Examinadora:

Prof. Dr. Farid Samir Beñavides Vañegas (Universidad de los Andes - Colômbia)

Prof. Dr. Rodrigo Guiringhelli Azevedo (PUC-RS)

Prof. Dr. Arthur Trindade Maranhão Costa (UnB-DF)

Prof. Dr. Martin-Léon Jacques Ibañez de Novión (UnB-DF)

Prof $^{\mathrm{a}}$. Dr ${ }^{\mathrm{a}}$. Simone Rodrigues Pinto (UnB-DF) - Suplente

Brasília

Março de 2016 


\section{Dedicatória}

Aos homens e mulheres da Polícia Militar do Rio de Janeiro e da Policía Nacional de Colombia, com respeito e gratidão. 


\section{Agradecimentos}

Agradeço, primeiramente, aos policiais e às policiais que se disponibilizaram a participar como sujeitos deste trabalho, com sinceridade e confiança.

Agradeço, igualmente, aos policiais e às policiais que me ajudaram a abrir as portas das polícias e encontrar o que buscava.

Agradeço imensamente às amigas, aos amigos, e familiares que me apoiaram incondicionalmente nesta longa trajetória de doutoramento.

Agradeço ao corpo docente do CEPPAC, que me inspirou e contribuiu de maneira ímpar para o meu processo de formação continuada no doutorado. E, nesse âmbito, aproveito para estender minha gratidão ainda aos funcionários do CEPPAC, pela paciência e boa vontade na ajuda com os trâmites e burocracias da universidade.

Agradeço ao Conselho Nacional de Desenvolvimento Científico e Tecnológico CNPQ, pela concessão da bolsa de estudos de doutorado durante o curso de doutoramento e também à Coordenação de Aperfeiçoamento de Pessoal de Nível Superior - Capes, pela bolsa de estudos sanduiche, a qual me permitiu realizar a pesquisa de campo na Colômbia.

Agradeço, especialmente, ao Professor Farid Samir Beñavides Vañegas, que me ajudou a dar passos decisivos na concretização do trabalho de campo na Colômbia.

Por fim, agradeço profundamente à minha orientadora Professora Rebecca Lemos Igreja, por sua dedicação, respeito, cuidado, parceria, ética e carinho, com os quais conduziu o processo de orientação. 


\section{Resumo}

\section{A TOMADA DE DECISÃO NAS RUAS: UM ESTUDO COMPARATIVO ENTRE A ATUAÇÃO DA POLÍCIA NO BRASIL E NA COLÔMBIA}

Este trabalho tem como objetivo principal a compreensão do processo de tomada de decisão dos policiais que trabalham nas ruas, no momento do acontecimento dos eventos. Para a consecução desse fim, a pesquisa compreendeu a fase de campo e de pesquisa bibliográfica. Nos trabalhos de campo, foram feitas pesquisas de campo no Brasil e na Colômbia, respectivamente nas cidades do Rio de Janeiro, Medellín e Bogotá. No campo, foram utilizadas técnicas de pesquisa qualitativa, como entrevistas em profundidade, observação participante e grupos de discussão. Os sujeitos desta pesquisa são as praças da Polícia Militar do Rio de Janeiro, alocados na UPP Santa Marta no Rio de Janeiro; e os patrulleros da Policía Nacional de Colômbia, alocados na Comuna 13 em Medellín. Este trabalho foi orientado pela perspectiva comparativa e, nesse sentido, a análise produzida desenvolvida com base nos resultados da pesquisa em ambos os países.

Palavra-chave: polícia, mandato policial, discricionariedade, tomada de decisão. 


\begin{abstract}
THE PROCESS OF DECISION MAKING IN THE STREETS: A COMPARATIVE STUDY BETWEEN THE ROLE OF THE POLICE IN BRAZIL AND COLOMBIA
\end{abstract}

This study aims to understand the decision-making process of the police officers that work on the streets at the time of the occurrences. To make this achievement, the research included the field phase and a literature search. In field work, the were made surveys in Brazil and Colombia, respectively in the cities of Rio de Janeiro, Medellin and Bogota. Also in this field work, qualitative research techniques were used as in-depth interviews, participant observation and discussion groups. The participants of this research were the squads of the Military Police of Rio de Janeiro, allocated in UPP Santa Marta in Rio de Janeiro; and patrulleros of the National Police of Colombia, allocated in Comuna 13 in Medellin. This work was guided by comparative perspective, and in that sense, the analysis produced was developed based on the results of the research in both countries.

Keyword: police, police command, discretion, decision making. 


\section{SUMÁRIO}

1.Introdução 11

1.1. A escolha do tema de pesquisa 14

$\begin{array}{ll}\text { 1.2.O primeiro encontro } & 16\end{array}$

1.3. Contextos de atuação dos sujeitos da pesquisa 19

1.4. Caminhos para se chegar a um fim 39

2.Metodologia 43

2.1. A pesquisa 43

2.2. A comparação 44

2.3. Estratégias de pesquisa $\quad 53$

2.4. Roteiro de entrevista

3.Percurso de entrada nos campos de pesquisa $\quad 58$

3.1.Colômbia $\quad 58$

3.1.2.Sobre a definição do território e foco de pesquisa 61

3.1.3.Perfil dos entrevistados 66

$\begin{array}{ll}\text { 3.2.Brasil } & 70\end{array}$

3.2.1.Entrada no campo de pesquisa - Rio de Janeiro 70

3.2.2. Sobre a definição das unidades de polícia, tempo e foco de 73 pesquisa

$\begin{array}{ll}\text { 3.2.3.Perfil dos entrevistados } & 77\end{array}$

4. Referencial teórico $\quad 81$

5. As Polícias 100

5.1.A tomada de decisão 101

5.2.Sobre a Policía Nacional de Colombia - PONAL 103

5.3.Sobre a Polícia Militar do Estado do Rio de Janeiro - PMERJ 111

6. Percepções sobre o trabalho de polícia 122 
6.2.Mandato de polícia 131

6.3.O que os policiais dizem sobre o processo decisório nas ruas $\quad 139$

7.Considerações finais 164

8. Referências bibliográficas 175

$\begin{array}{ll}\text { Anexo I } & 183\end{array}$

$\begin{array}{ll}\text { Anexo II } & 186\end{array}$

$\begin{array}{ll}\text { Anexo III } & 192\end{array}$

$\begin{array}{ll}\text { Anexo IV } & 193\end{array}$

$\begin{array}{ll}\text { Anexo V } 223 & 223\end{array}$

$\begin{array}{ll}\text { Anexo VI } & 241\end{array}$

$\begin{array}{ll}\text { Anexo VII } & 287\end{array}$

$\begin{array}{ll}\text { Anexo VIII } & 296\end{array}$ 


\section{LISTA DE SIGLAS}

\begin{tabular}{l|l} 
PMERJ & Polícia Militar do Estado Rio de Janeiro \\
\hline PONAL & Policía Nacional de Colombia \\
\hline UPP & Unidade de Polícia pacificadora \\
\hline UFF & Universidade Federal Fluminense \\
\hline UERJ & Universidade do Estado do Rio de Janeiro \\
\hline SENASP & Secretaria Nacional de segurança Pública \\
\hline LAV & Arma de fogo \\
\hline DNP & Laboratório de Análise da Violência \\
\hline FARC-EP & Departamento Nacional de Planificación \\
\hline ELN & Fuerzas Armadas Revolucionarias de Colombia - Ejército Popular \\
\hline BACRIM & Ejército de Liberación Nacional \\
\hline GAOML & Bandas criminales \\
\hline ONU & Grupo armado organizado al margen de la ley \\
\hline PNUD & Organização das Nações Unidas \\
\hline FLACSO & Programa das Nações Unidas para o Desenvolvimento \\
\hline DMS & Facultad Latinoamericana de Ciencias Sociales \\
\hline E.U.A. & Departamentos y Municipios Seguros \\
\hline CAP & Costados Unidos da América \\
\hline UNIANDES & Universidad de los Andes \\
\hline ESPOL & Escuela de Posgrados de Policía \\
\hline IAP & Investigación Acción Participación \\
\hline MEVAL & Metropolitana del Valle de Aburrá \\
\hline CAI & Centro de Atención Imediata \\
\hline EMG & Estado Maior Geral \\
\hline CEFAP & Centro de Formação e Aperfeiçoamento de Praças 31 de Voluntários \\
\hline TAMIR & Tabla de Acciones Minimas Requeridas \\
\hline SESEG & Secretaria de Estado de Segurança \\
\hline GPAE & Grupamento de Policiamento em Aareas Especiais \\
\hline PVCC & Plan Nacional de Vigilancia Comunitária por Cuadrantes \\
\hline POP & Procedimento Operacional Padrão \\
\hline SEA & Saludar, escuchar, actúar \\
\hline
\end{tabular}




\section{INTRODUÇÃO}

A questão da segurança pública na América Latina vem sendo enfrentada por meio da implementação de políticas voltadas à redução da violência, como também ao aprimoramento da atuação de polícia. Consequentemente, o tema reforma de polícia vem ocupando uma posição destacada, fato que pode representar, ao menos, uma tentativa de transversalizar valores democráticos na prática policial.

O debate sobre a modernização das instituições policiais foi adiado por um longo
período, mas já a partir da década de 90 , com o incremento da criminalidade, o tema
entrou em pauta, com questões relacionadas à letalidade policial, à formação policial,
à ineficiência da investigação criminal, à falta de controle institucional e à
desmilitarização das polícias sendo amplamente debatidas por diversos atores sociais
e institucionais. (AZEVEDO, 2016, p. 9-10)

A partir dos anos 90, em diversos países latino-americanos, a concepção de polícia cidadã passou a representar o papel que se espera das polícias em democracias. A atuação cidadã policial, grosso modo, se traduz em colocar o cidadão e seus direitos no centro da atenção dos Estados latino-americanos. No entanto, a resposta dos governos à questão do aumento da violência e crescente percepção de insegurança, para ser eficaz, deve ser levada a cabo de maneira continuada e comprometida. Notoriamente,

\footnotetext{
Ante el incremento recurrente de los índices de delincuencia, los gobiernos latinoamericanos en general responden con discursos y prácticas erráticas al tiempo que no se comprometen a proporcionar el respaldo político y las inversiones necesarias para que las instituciones de seguridad puedan cumplir la tarea que les corresponde. (GONZÁLEZ, 2015, p.121)
}

O narcotráfico e outros tipos de crimes organizados como tráfico de armas, de pessoas dentre outros, são fenômenos que transcendem os limites territoriais entre os países, e impõem 
aos governos grandes desafios. Em este cenário, as polícias, herdeiras de práticas violentas e violadoras de direitos exacerbadas nos períodos de regimes militares contribuem com o aumento da violência e descrença na capacidade de governança de seus governos.

Cabe destacar que, mesmo que os países latino-americanos tenham feito a transição a democratização, a violência policial se mantém no topo das preocupações populares. Tal centralidade da ação de polícia reflete a importância desse ator no jogo democrático ${ }^{1}$. Sendo a polícia o braço armado do Estado, sua atuação denuncia para quem e para que a força pública está sendo aplicada, ou seja, quais são as prioridades políticas dos governantes.

Contudo, a violência policial sofreu mudanças a partir do processo de democratização latino-americano. Estas mudanças são percebidas no alvo de sua ação violenta. Antes da implementação de democracias, as polícias se voltavam para líderes políticos contrários à bandeira política dominante, que podiam ser quaisquer atores que representassem uma ameaça real ou potencial. Com a transição democrática, a força policial deixou de lado os inimigos políticos para ter como alvo "os segmentos excluídos, os presidiários, os trabalhadores rurais e as minorias radicalmente discriminadas" (COSTA, 2004, p. 17).

No Brasil, a violência policial remonta sua criação na então capital da república no Rio de Janeiro (BRETAS, 1997; HOLLOWAY, 1997). Na Colômbia, o contexto de violência policial está relacionado a questões políticas, que levaram a perseguição e assassinatos de opositores aos governos vigentes. Resultante desse cenário, surgiram os grupos de resistência armada, sendo o mais notório as chamadas Forças Revolucionarias Colombianas-Exército Popular (FARC-EP). A guerrilla colombiana deflagra um movimento insurgente armado em expansão, cujo confronto com as polícias verificou-se inevitável e violento. Associado a este

\footnotetext{
${ }^{1}$ Cabe esclarecer que o uso da formatação em itálico para palavras ao longo do texto, foi aplicado por dois motivos: 1) destacar a ideia transmitida pela palavra ou expressão em português; 2) palavras em idioma estrangeiro, exceto em espanhol. Como no texto há uma quantidade expressiva de palavras em espanhol, optouse por não usar o formato itálico por uma questão de estética textual.
} 
fenômeno está a ascensão do poder do narcotráfico na Colômbia, que se converteu em um elemento fundamental para a compreensão da violência no país.

\begin{abstract}
Podríamos señalar que el problema de la droga en la sociedad colombiana ha obrado como un especie de articulados y disparador de múltiples elementos que ya estaban presentes en la realidad colombiana: corrupción, desconfianza en la política y los políticos, incredibilidad institucional, las múltiples violencias. (A.VELÁSQUEZ, 1999, p.11)
\end{abstract}

Depois da promulgação da Constituição Colombiana de 1992, foi iniciado um processo de reforma policial, culminando na expulsão de mais de

10.000 miembros, que por distintos motivos no se adecuaban a los nuevos requerimientos de una policía respetuosa de los derechos humanos y cercana a las necesidades y confianza de los ciudadanos de Colombia (H.VELÁZQUEZ, 2008, p.2)

As polícias, portanto, estão no centro da atenção pública quando os assuntos são violências, repressão, direitos humanos e democracia, dentre outros. O papel que desempenham é de grande relevância, dado que representam a força pública aplicada na e para a sociedade, com o objetivo de exercer controle social sobre a mesma e preservar a ordem pública. Popularmente, as polícias são rejeitadas justamente porque representam a repressão armada, que historicamente, vem sendo direcionada aos que integram as camadas mais pobres da sociedade, aos inimigos da ordem vigente e aos que tem comportamento inadequado ou indesejado. Nessas grandes categorias de atores se agrupam um número sem fim de pessoas, de acordo com o momento histórico e temporal sob o qual a análise se debruça.

Assim, a escolha por estudar a tomada de decisão nas ruas por parte dos policiais que realizam o policiamento ostensivo parece abordar um aspecto fundamental da relação entre polícia e sociedade, mediada por interesses diversos dos governos (e não raro contraditórios aos valores democráticos), por conflitos sociais e políticos, e pelas idiossincrasias dos grupos sociais que conformam uma sociedade. Esse trabalho buscou compreender os mecanismos, 
insumos e ferramentas utilizadas por esses profissionais nas ruas, ou seja, no calor e na imediatez dos fatos, quando uma resposta profissional, qualificada e resolutiva é esperada. Esses são os momentos onde a força e o poder policial são concretizados e colocados em xeque, e são os momentos privilegiados por esta pesquisa.

\subsection{A ESCOLHA DO TEMA DE PESQUISA}

O tema deste trabalho é a tomada de decisão dos policiais que fazem o policiamento ostensivo no momento e no calor da ação. A proposta de pesquisa foi elaborada desde a perspectiva comparativa, adotando como recorte espacial para a comparação as cidades do Rio de Janeiro (Brasil) e Medellín (Colômbia) e, como sujeitos de pesquisa, os policiais militares da Polícia Militar do Rio de Janeiro (PMERJ) alocados na Unidade de Polícia Pacificadora (UPP) no morro Santa Marta e os patrulleros da Policía Nacional de Colombia (PONAL), alocados na Estación de Policía San Javier da Comuna 13. A questão fundante do tema escolhido se centra na intrigante capacidade que os policiais demonstram ter, na empiria cotidiana da profissão, para decidir o que fazer, como fazer, com qual intensidade aplicarão a força real ou potencial, em tempo incontável, diante de um evento que demanda uma resposta imediata, mesmo que provisória. A polícia, em geral, é chamada para tudo que altera a funcionalidade da vida societária. É, ao menos, admirável o uso dessa capacidade de desempenhar um sem-fim de atividades e, para cada uma, elaborar uma reação com o termo de resolução da problemática. Torna-se evidente que essa escolha também foi influenciada pelo trabalho de mestrado, a qual persiste como questão relevante para o aprofundamento sobre o trabalho de polícia nas ruas, ou o fazer polícia diuturnamente desempenhado. 
Considerando que atuação de polícia pode representar um número indefinido de atividades, já que a atuação de polícia pode ser observada desde distintas perspectivas e ainda nas diversas dimensões da prática policial, cabe ressaltar que, para esse estudo, a comparação sobre a atuação de polícia teve como recorte a tomada de decisão nas ruas, realizadas pelos policiais que fazem o policiamento ostensivo. Dessa forma, a escolha recortada definiu que, quem e onde a observação foi realizada, e, consequentemente, não pretendeu esgotar a atuação de polícia em sua totalidade e abrangência.

No conjunto de motivações para a escolha do tema, vale incluir minha experiência enquanto cidadã carioca. Não são incomuns, na dinâmica da chamada cidade maravilhosa, conflitos violentos envolvendo a polícia e, massivamente, os policiais militares, já que são justamente estes os que estão no front da segurança pública como representantes in loco do Estado. O "caráter popular [grifo no original] da Polícia Militar expressa e materializa o poder de polícia de forma rica em termos de encontros e interações com a sociedade" (ANJOS, p. 14, 2010). E, no Rio, o braço armado do poder público deixa um legado de memórias marcadamente violentas de confrontos armados entre policiais e cidadãos. Há décadas, o assunto segurança pública tem sido a pauta do dia para políticos, gestores e conversas de botequim. Nesse sentido, o tema atuação de polícia marcou minha experiência social e acabou por se desdobrar na curiosidade acadêmica canalizadas nos cursos de especialização e mestrado e, agora, na tese de doutorado. A continuidade desse estudo, explorado em distintos e variados enfoques, imprime à minha trajetória uma percepção de aprofundamento sobre o tema.

Assim, este trabalho se concentra na questão relativa aos mecanismos e insumos que informam e habilitam a tomada de decisão dos policiais nas ruas diante de um evento que lhes exige intervir. Como fazem o cálculo sobre que estratégias irão utilizar para produzir obediência circunscrita à lei e igualmente amparada pela legitimação da ação, e sob que medida? Em que se baseiam para elaborar o sob medida da ação em um cenário que é, por natureza, 
imprevisível? Quais mecanismos são acionados no ato de definir o caminho a ser levado ao fim esperado? Em suma, são estas as inquietações provocadoras da pesquisa desenvolvida.

\subsection{O PRIMEIRO ENCONTRO}

Para falar sobre a concepção, construção e propósitos deste trabalho, considero importante iniciar tal abordagem expositiva por meio de uma breve revisão dos aspectos da minha trajetória que me motivaram a ingressar no campo de pesquisa de segurança pública e polícia.

Em 1999, ainda estudante de graduação em Serviço Social na UFRJ, optei por fazer o estágio obrigatório exigido para a conclusão do curso, em instituições relacionadas ao tema violência. Esse tema me chamava a atenção tanto pela multiplicidade de formas como, sobretudo, pela recorrência de eventos no cotidiano da cidade.

Foi feita, então, a escolha - e aqui devo confessar que o uso do termo escolha se apresenta intencionalmente, vindo revestido com o propósito de provocar o primeiro contato com o tema desta pesquisa, que é justamente a tomada de decisão. E por trabalhar com a temática da violência, identifiquei, então, em meio às opções disponíveis, em que direção daria o meu primeiro passo rumo ao esperado profissionalismo. Meu primeiro estágio, portanto, foi em uma unidade do sistema prisional fluminense. Meu aprendizado transcorreu em grande parte pela dor e pelo choque do contato com o que se pode chamar de o fim da linha de trajetórias classificadas como à margem da lei, que, sob a proteção da lei, permanecem em estado de vitimização por parte do Estado. Assim se deu o meu ritual de batismo necessário ao ingresso no controvertido e diverso universo das violências e da criminalidade. Meu segundo e último período de estágio foi em uma instituição pública de atendimento a mulheres vítimas de 
violências. Nos meses de estágio, aprendi com as mulheres, em uma realidade na qual o inimigo é outro, ou seja, o vilão ou o inimigo gozam da intimidade da pessoa vitimizada, bebem da fonte de seus sonhos. Dessa vez, o aprendizado - igualmente pela dor - foi por meio da identificação inevitável e por uma questão também de gênero, o que me levou à penosa assunção: "Eu não era exceção". Essas duas experiências me aproximaram e me introduziram nos variados temas associados à violência, bem como a práticas institucionais nos espaços onde estive.

O primeiro contato com as polícias ocorreu no período em que estava em uma secretaria do governo estadual, já graduada e como assistente de projetos. Nesse período, participei de projetos de treinamento e pesquisa com e sobre policiais. A partir desse contato, decidi aprofundar os meus conhecimentos acerca do tema, a partir de um curso de especialização sobre segurança pública, no qual pude, por alguns meses, compartilhar concepções e expectativas sobre segurança pública e polícia, em sala de aula com oficiais da PMERJ, então “colegas” de turma.

Como fiz parte de uma das primeiras turmas do curso, tudo era novo tanto para mim quanto para eles (os policiais) e para a UFF, onde o curso foi implementado. Por fim, integrávamos um experimento. Vale relembrar uma passagem significativa sobre a relação em construção entre mim e os colegas policiais: sempre gostei de sentar na primeira fileira de carteiras desde criança. Então chegava cedo à sala e ocupava o lugar que mais gostava: na primeira fileira e na primeira carteira do lado esquerdo da sala, junto à janela. Durante as primeiras aulas, repeti esse mesmo movimento. Até que um dia fui abordada por alguns oficiais, que me perguntaram se eu não poderia passar para a fileira de trás. Instantaneamente me recusei, explicando que gostava daquele lugar por ser perto da janela e também na primeira fileira. Não satisfeitos com a minha resposta, tentaram me persuadir a mudar. Eu continuei firme na negação. 
Mediante meu incontornável "não", eles organizaram outra fileira na frente da minha, fazendo com que a minha carteira passasse para a segunda fileira e me pediram para chegar um "pouquinho pra trás", pois, assim, ficaria atrás deles, mas perto da janela. Não tive outra escolha simplesmente porque empurraram minha carteira comigo ainda nela sentada. No intervalo, comentei com outros oficiais o que havia ocorrido em uma tentativa de encontrar alguma racionalidade naquele episódio. Esses policiais, então, me explicaram que, nos cursos na PM, a primeira carteira do lado esquerdo da sala na primeira fileira é reservada necessariamente ao "mais antigo", ou seja, ao policial de maior nível hierárquico do grupo. Sendo assim, aquele lugar estaria destinado a um tenente-coronel, e este demandava o exercício de seu "direito" à força.

A partir deste dia, com o olhar mais treinado e qualificado, notei que a sala de aula era dividida espacialmente segundo a hierarquia militar. A primeira fileira reservada aos tenentescoronéis; as demais, aos majores. Os "mais modernos" ocupavam a última fileira de carteiras. Para eles, o fato de eu não ser policial e ainda mulher me colocou no limbo desse espaço. Assim, em alguns dias brigava pelo meu espaço preferido; em outros, desistia da pelea. O melhor desse período, além do conhecimento adquirido e da rede de conhecimentos conquistada, foi o mergulho no mundo policial não tão de fora, mas também não totalmente de dentro. Foi este o meu primeiro (e inesquecível) encontro com a imposição da autoridade policial - talvez, nesse caso, engrossado pelo autoritarismo.

A partir daí, prossegui na trajetória acadêmica no curso de mestrado na Universidade do Estado do Rio de Janeiro (UERJ), quando concluí a dissertação intitulada “O poder de polícia: um estudo sobre as percepções dos policiais militares do Estado do Rio de Janeiro sobre o poder de polícia” (2010), até chegar ao atual momento acadêmico de doutoramento. 


\subsection{Contextos de ATUaÇão dos SuJEitos da PESQuisa}

No Brasil, as iniciativas de segurança pública são formuladas na esfera do governo federal, por meio da Secretaria Nacional de Segurança Pública (SENASP), que está vinculada ao Ministério da Justiça. A SENASP, portanto, desenvolve e implementa a Política Nacional de Segurança Pública ${ }^{2}$ com o objetivo, grosso modo, de promover alinhamentos conceituais e empíricos junto aos entes federados (municípios, estados e distrito federal) para o desenvolvimento de políticas locais.

A concepção democrática da segurança pública encontra seu marco de jurídico-político na Constituição brasileira de 1988, chamada Constituição Cidadã. Nesse marco, a segurança pública passa a ser adotada como um "dever do Estado e responsabilidade de todos" (Constituição Federal, 1988, artigo 144), fato que confere à segurança pública a condição de direito. A partir de então, o papel da polícia se consolidou segundo a natureza civil de seu trabalho. Cabe destacar que esse fato registra uma mudança de paradigma para a atuação da polícia, que a inscreve no paradigma da segurança pública. Anteriormente, o paradigma de segurança nacional pautava a atuação das polícias e das forças armadas (Marinha, Exército e Aeronáutica). Existem diferenças significativas entre os dois paradigmas - abaixo apresentadas - que demonstram um avanço na concepção do trabalho e emprego da força policial em uma sociedade democrática.

\footnotetext{
${ }^{2}$ Para ter acesso a alguns debates sobre a Política Nacional de Segurança Pública, veja os artigos disponíveis nos links a seguir. http://www.scielo.br/scielo.php?script=sci_arttext\&pid=S0103-40142007000300006 http://www.scielo.br/pdf/rk/v14n1/v14n1a07.pdf http://www.scielo.br/scielo.php?script=sci arttext\&pid=S1806-64452006000200007\&lng=pt\&nrm=iso
} 


\section{Quadro 1: Comparação entre os paradigmas de segurança nacional e segurança}

\section{pública}

\begin{tabular}{|c|c|c|}
\hline & Paradigma Segurança Nacional & Paradigma Segurança Pública \\
\hline$\underset{8}{8}$ & $\begin{array}{l}\text { Soberania nacional } \\
\text { Proteção de fronteiras e territórios }\end{array}$ & Garantia da pessoa humana e do patrimônio \\
\hline 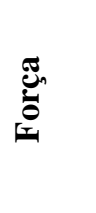 & $\begin{array}{l}\text { Combatente } \\
\text { Sustentação do Estado de Direito } \\
\text { Marinha, Aeronáutica e Exército }\end{array}$ & $\begin{array}{l}\text { Comedida } \\
\text { Sustentação do Estado de Direito } \\
\text { Polícias (estaduais e federais), Corpo de } \\
\text { Bombeiros e Guardas Municipais }\end{array}$ \\
\hline : & Questões internas e externas & Questões internas \\
\hline
\end{tabular}

Assim concebida, a política de segurança pública deve ser pautada para atender aos valores e interesses democráticos, e, por consequência, democratizar suas agências executoras: as polícias. Elaborada para ser um conjunto de diretrizes de caráter orientador, a política nacional ganhou materialidade por meio de planos, que organizam as ações a serem executadas segundo os conceitos e valores estabelecidos na política nacional. Até a atualidade, foram elaborados dois Planos Nacionais de Segurança Pública ${ }^{3}$ nos anos de 2000 e 2002, que, por sua vez, em momentos distintos, lançaram alguns programas com propósitos específicos. Ambos os planos e programas derivados deles foram demonstrações de organização e indução de conceitos e valores na esfera das ideias, e na dimensão prática de projetos alinhados ao processo democratização somado à conjuntura de crescente criminalidade, aumento de violências, inclusive da violência policial ou violência estatal.

\footnotetext{
${ }^{3} \mathrm{O} 1^{\circ}$ Plano Nacional de Segurança Pública pode ser encontrado no link http://www.observatoriodeseguranca.org/files/PNSP\%202000.pdf . O $2^{\circ}$ Plano pode ser acessado no link http://www.justica.gov.br/sua-seguranca/seguranca-publica/senasp-1/pnsp.pdf
} 
No desenho brasileiro político-administrativo traçado pelo pacto federativo ${ }^{4}$, a gestão federal desenvolve a política a ser adotada pelos entes federativos, que gozam de autonomia administrativa para aderir ou não a política nacional.

Essa especificidade do caso brasileiro produz uma fragmentação na política de segurança, por ser desenvolvida na esfera do governo federal para ser executada pelos entes federados, de acordo com injunções e interesses localmente definidos. Esse é um esquema complexo, com imbricamentos que demandam a criação de "alianças políticas entre governos estaduais e governo federal, mediadas pelas ligações entre bancadas estaduais e federais que não raro controlam lobbies muito poderosos como os das corporações policiais e judiciais" (ADORNO, 1999, p. 141). O autor sinaliza, assim, que há problemas estruturais na implementação da política nacional de segurança, que diante da tarefa de implementar uma gestão democrática eficiente, se confronta com o jogo político. A despeito das dificuldades e frustrações que geram a tentativa de gestão compartilhada da política nacional e das políticas locais de segurança pública, a proposta se configura em um importante incentivo à capacidade de governança das administrações públicas locais sobre os índices de violência que produzem na sociedade uma crescente percepção de insegurança e baixa credibilidade nos governos.

A questão central para a política de segurança pública, e, portanto, brasileira, é a violência letal causada por armas de fogo em escalada crescente. Excluindo suicídios e mortes acidentais por arma de fogo (AF), o crescimento do número de assassinatos apresenta um aumento exponencial, passando de 8.710 casos em 1980 a 44.861 em 2014, segundo dados do Mapa da Violência 2016. Nesse lapso de tempo houve um aumento aproximado de $65 \%$ de população no país, que quando comparado ao crescimento de $415 \%$ no mesmo período revela um problema social ainda não enfrentado eficazmente pelo Estado brasileiro.

\footnotetext{
${ }^{4} \mathrm{O}$ pacto federativo brasileiro visa a descentralização política dos entes federados, e consolidando as noções de autonomia e união entre as partes. Os entes federados podem, assim, estabelecer suas próprias legislações desde que não representem desrespeito a à legislação federal. Podem também estabelecer sus próprias políticas, que igualmente deve estar alinhada à política nacional.
} 
Como vemos pelos números, os homicídios representaram, ao longo do período analisado, $85,8 \%$ do total de mortes por armas de fogo. Mas uma grande parte da massa de mortes por AF de causalidade indeterminada deveria ser creditada na fileira dos homicídios. Por esse motivo, é possível afirmar que praticamente $95 \%$ da utilização letal das armas de fogo no Brasil tem como finalidade o extermínio intencional do próximo. (Mapa da Violência, 2016, p. 15)

Particularmente, a questão da criminalidade crescente no país vendo sendo associada, principalmente, à violência urbana, que se traduz em distintas modalidades, como violência decorrente do enfrentamento armado entre facções criminais pelo domínio de territórios e controle da comercialização de drogas, e com a polícia, como também outros crimes como homicídios, roubo, furto ${ }^{5}$ etc. Secundariamente, estão as violências intrafamiliar, de gênero, contra crianças e idosos, população de rua e outros segmentos sociais. Em todas as situações, a instituição policial ocupa um papel prioritário porque a ela se atribui a tarefa de controle da violência e da criminalidade, esperando que da polícia surja a resposta para tais fenômenos. Para Costa,

A discussão sobre a qualidade e adequabilidade das instituições policiais tem aumentando consideravelmente. Em boa parte, isso é resultado do aumento das taxas de criminalidade e da sensação de insegurança em diversas cidades, bem como da reação violenta e, às vezes, descontrolada das polícias. Dois temas têm recebido bastante destaque na presente discussão: a necessidade de políticas mais efetivas de segurança pública, que permitam uma redução nos índices de criminalidade, e a necessidade de reformas nas instituições policiais, que permitam uma maior adequação ao contexto sociopolítico dos regimes democráticos. (COSTA, 2004, p. 104)

As estatísticas brasileiras revelam que a letalidade da ação policial contribui com o alto números de mortes no país. Segundo o Anuário Brasileiro de Segurança Pública 2015, houve

\footnotetext{
${ }^{5} \mathrm{Na}$ legislação penal brasileira, roubo e furto são ações de subtração de um bem alheio sem o consentimento do proprietário. Entretanto, o roubo ocorre com ameaça ou violência, enquanto que o furto ocorre sem esta conduta. Assim, ambos são condutas criminais, porém com as ditas distinções, que implicam em imputação diferenciada de pena.
} 
um total de 58.497 mortes violentas em 2014, o que significa $28,8 \%$ mortes para cada cem mil habitantes. Comparando a letalidade policial entre 2013 e 20014, se registra um aumento de 37,2\%, com um total absoluto de 3.009 mortes. Esse cenário indica que a prática policial no Brasil é violenta, como também geradora de medo e insegurança na população; da mesma forma, sinaliza que a polícia representa um nicho de resistência à democratização do Estado, que deve ser tratado com medidas de reforma estrutural, capazes de produzir mudanças significativas e urgentes.

Os estados brasileiros possuem duas polícias - a militar e a civil - com responsabilidades distintas ${ }^{6}$. À polícia militar cabe o policiamento ostensivo, enquanto que a polícia civil assume a função de polícia judiciária, dito de forma resumida. As duas polícias realizam todas as suas atribuições de maneira independente entre si, contudo, ambas estão subordinadas ao poder executivo local e estão vinculadas à mesma unidade de gestão pública. O governador do estado é o chefe máximo das polícias estaduais, que mantém sob sua autoridade o Chefe de Polícia Civil e o Comandante da Polícia Militar. Esse esquema organizativo permite ao governo estadual manter o controle sobre sua força armada e proteger o poder estabelecido, assim como, impor-lhes as prioridades definidas pela política de governo. Contudo, em consequência, as polícias não possuem autonomia para implantar suas próprias políticas, o que pode resultar em um conflito de interesses vinculados a diferentes concepções de segurança pública e ao papel da instituição policial em uma democracia.

No Rio de Janeiro, as Polícias Civil e Militar estão vinculadas à Secretaria Estadual de Segurança Pública ${ }^{7}$, que desde 2008 adotou um modelo de policiamento chamado polícia pacificadora, realizado pela Polícia Militar. As Unidades de Polícia Pacificadora ${ }^{8}$ (UPP)

\footnotetext{
${ }^{6}$ Sobre os papéis das polícias estaduais com base na Constituição de 1988, ver a obra Controle da criminalidade e segurança pública: na nova ordem constitucional, de Jorge da Silva, que apresenta uma perspectiva crítica do assunto.

${ }^{7}$ Ver a página da secretaria no link http://www.rj.gov.br/web/seseg

${ }^{8}$ Ver a página das UPP no link www.upprj.com para mais informações.
} 
representam e dão materialidade à estratégia de implantação de unidades policiais em áreas que não faziam parte do patrulhamento regular - as favelas cariocas. Nesse sentido, a concepção de polícia pacificadora é restrita as áreas onde a violência e o enfretamento armado entre policiais e facções criminais ligadas ao narcotráfico transformavam o cotidiano em cenários de guerra civil. Fora das favelas, a orientação do policiamento ostensivo varia entre: tradicional, comunitário, orientado para resolução de conflitos e, mais recentemente, pela polícia de proximidade 9 . Não obstante os esforços implementados pela Polícia Militar para ajustar a prática policial às demandas democráticas, a variação de modelos de policiamento em espaços de tempo insuficientes para a consolidação de mudanças, resulta na persistência de posturas policiais formadas pelo ethos guerreiro ${ }^{10}$ de eliminação do inimigo, oriundo da criação da polícia militar como força auxiliar do exército, alimentada pela socialização da existência de um estado de guerra civil ${ }^{11}$ contra o tráfico de drogas.

Este raciocínio se aplica às UPP, pois mesmo se mantendo como uma política em implementação desde 2008, em um número crescente de favelas, pode-se notar que as críticas ao programa anunciam um processo de descaracterização da iniciativa ${ }^{12}$. A Polícia Civil, por sua vez, passou por um processo de reforma iniciado em 1999, quando o Programa Delegacia Legal foi lançado. Este programa de reforma ${ }^{13}$ visava a modernização das estruturas físicas das

\footnotetext{
${ }^{9}$ Ver capítulo 5.3 Sobre a Polícia Militar do Estado do Rio de Janeiro - PMERJ

${ }^{10}$ Sobre o ethos guerreiro do policial militar, ver: dissertação de mestrado de Paulo Storani Vitória Sobre a Morte: A Glória Prometida (2008); Tese de doutorado de Jacqueline Muniz Ser policial é sobretudo uma razão de ser (1999); o artigo Galeras funk cariocas. Os bailes e a constituição do ethos guerreiro, de Fatima Cecchetto, (1998), em: Um Século de Favela.

${ }^{11}$ Em 1999, foi lançado um documentário intitulado Notícias de uma Guerra particular (disponível em https://www.youtube.com/watch?v=EAMIhC0klRo), que reificou a noção de guerra na cidade do Rio de Janeiro entre traficantes de drogas e policiais, e ainda revelou suas percepções sobre a particularização de questão de segurança pública.

${ }^{12} \mathrm{O}$ estudo sobre as UPP realizado pelo Fórum Brasileiro de Segurança e Laboratório de Análise da Violência (LAV/UERJ), lançado em 2012, aborda o impacto da implementação do programa. O documento pode ser obtido no link http://www.forumseguranca.org.br/storage/download/os donos do morro.pdf

${ }^{13} \mathrm{O}$ trabalho O Programa Delegacia Legal no Rio de Janeiro: Avaliação de uma Experiência Modernizadora na Polícia Civil Brasileira (falta data) apresenta críticas importantes e pode ser acessado na página http://necvu.ifcs.ufrj.br/arquivos/Relatorio_PDL_fim.pdf
} 
delegacias e democratização dos procedimentos policiais, com o objetivo de aproximar a polícia judiciária dos ideais cidadãos.

Por décadas, as polícias brasileiras vêm adotando práticas violentas, que resultam em morte daqueles que se opõem a sua força ou autoridade. As polícias fluminenses ${ }^{14}$ e paulista têm mantido posições elevadas no ranking nacional segundo os dados apresentados no Anuário de Segurança Pública do Fórum Brasileiro de Segurança Pública (2016) no que se refere à violência policial. Na história fluminense, algumas vezes a violência era assinada por grupos especiais encarregados de limpar as ruas da sujeira da criminalidade; outras vezes, a higienização era velada e anônima. O mais importante é que em ambas situações, a estratégia de eliminação do mal $^{15}$ ocupava o espaço da resolução de problemas e conflitos, como também, de uma política de segurança pública que tratasse a questão de maneira profissional. Para Misse,

Desde a criação dos chamados 'esquadrões da morte' [grifo no original], ainda nos anos 50, a fama de violência da polícia carioca e fluminense só fez crescer. São inúmeros os relatos que confirmam que não apenas a polícia, mas uma parte significativa da sociedade fluminense sempre acreditou que torturar e matar bandidos era uma solução para a criminalidade. Ao aumento das soluções violentas, muitos bandidos responderam com mais violência. (...) À impunidade de policiais violentos e corruptos somaram-se os mesmos fatores que fazem os bandidos: a cultura do machismo, o ethos da guerra, a valorização da força física e da tecnologia da rapidez e da resistência (nos carros), do alcance e da letalidade (nas armas), do domínio e da virilidade (na relação sexual), do dinheiro e do status (nas relações sociais). (MISSE, 2004, p. 191-192)

A UPP carioca onde foram realizadas as entrevistas com policiais está localizada no morro Santa Marta ${ }^{16}$, no bairro de Botafogo, zona sul da cidade, e recebeu o nome da própria

\footnotetext{
${ }^{14}$ As pessoas (ou instituições) nascidas na capital do estado do Rio de Janeiro são chamadas cariocas. Os que nasceram foram da capital são chamados fluminenses. No caso de instituições, as que tem abrangência estadual, usualmente, são chamadas fluminense para diferenciar das que se concentram na capital. Nesse trabalho, a expressões carioca e fluminense serão empregadas seguindo esta mesma linha de pensamento.

${ }^{15}$ Ver Criminalidade, violência e imagens no Rio de Janeiro, de Sento-Sé. In: O mal à brasileira.

${ }^{16}$ Nos links a seguir podem ser encontrados trabalhos que contextualizam o morro Santa Marta a partir de temas específicos, como a implantação da UPP e questões urbanísticas.

http://biblioteca.clacso.edu.ar/clacso/becas/20131231022532/PolicyBrief.pdf

file:///C:/Users/veronica/Documents/Veronica/OEA/2064-3505-1-SM.pdf
} 
comunidade local, sendo chamada por UPP Santa Marta. Segundo dados da UPP ${ }^{17}$, a população local é de quatro mil habitantes, aproximadamente. A política de pacificação foi inaugurada no morro Santa Marta em 2008, com a implantação da primeira UPP, considerada modelo a ser seguido para as demais pela própria polícia. A geografia do morro é peculiar pelo fato de este estar incrustrado em uma área montanhosa muito íngreme, a qual não se comunica com nenhuma outra, exceto com o bairro de Botofago no asfalto. Não há acesso por dentro para veículos, somente por escadas. Devido à dificuldade de acesso, foi implantado um sistema de carros de plano inclinado, popularmente conhecido como bondinho. Pelos dados de criminalidade $^{18}$ no morro, a exemplo dos crimes de homicídio no ano de 2007 , registraram-se dois casos. Nos anos subsequentes até 2015, não houve mais homicídios.

Para ter acesso as vielas e becos que conformam o território, a comunidade do Santa Marta deve subir por uma longa escadaria, que corta a comunidade. $\mathrm{O}$ fato de ser um plano de elevação acentuada provoca grande desgaste físico na comunidade, principalmente quando do transporte de pessoas enfermas ou com dificuldade de locomoção, de cargas, e de idosos. O bondinho ajuda, porém não soluciona o problema totalmente por parar somente em estações definidas, que podem estar distantes de alguns setores. Outra questão com relação ao bondinho é a manutenção dos vagões. Segundo relatos, a comunidade fica sem o serviço com frequência por falta de assistência técnica, por avarias referentes ao uso, e pela necessidade de renovação dos vagões, que se desgastam rapidamente devido ao uso permanente.

http://peep.ebape.fgv.br/sites/peep.ebape.fgv.br/files/O_Mercado_Sobe_o_Morro_A_Cidadania_Desce Estudo Sobre os Efeitos da Pacificacao no Santa_Marta.pdf http://unuhospedagem.com.br/revista/rbeur/index.php/anais/article/viewFile/4254/4124

${ }^{17}$ Os dados organizados pelas UPPs sobre as comunidades nas quais estão, podem ser obtidos na página institucional www.uppri.com

${ }^{18}$ O Instituto de Segurança Pública (ISP) é o órgão do governo do estado que elabora as análises oficiais de criminalidade. Na sua página de internet se encontram as estatísticas do estado e das favelas onde estão implantadas as UPP. Ver www.isp.ri.gov.br para estatísticas do estado, e http://www.isp.rj.gov.br/Conteudo.asp?ident=61 para as estatísticas das UPP. 
A circulação pelo interior da comunidade é difícil, pois as escadas são estreitas, já que as casas estão imediatamente ao lado da escadaria. Em alguns trechos, devido à aglomeração de casas, há pouca luz. As construções são sobrepostas uma as outras, ou seja, as paredes que separam as casas em muitos casos se fundem, sem deixar espaços livres ou quintais. Com frequência, há lixo acumulado, escombros de obras, e objetos diversos despejados nos espaços comuns. Em alguns trechos, o mal odor do esgoto que corre ao ar livre pela comunidade predomina no ambiente. Não há espaços de lazer para as crianças, a exceção de uma quadra, onde existe o busto do cantor Michael Jackson, em homenagem a sua presença em 1996 para gravação de um vídeo clip.

A favela apresenta uma divisão sócio espacial, que impõem as partes mais altas, as condições mais desfavoráveis, enquanto na parte baixa onde inicia a vizinhança do asfalto do bairro Botafogo, o cenário muda. Na entrada baixa do morro, pode-se encontrar um comércio variado formado por biroscas, ambulantes e vendinhas. Nesse trecho se concentra o comércio local, onde se comercializa grande sorte de produtos que fazem parte das necessidades cotidianas das famílias.

Na Colômbia, em 2011, foi lançada a Política Nacional de Seguridad y Convivencia Ciudadana (PNSCC) $)^{19}$, cujo documento foi elaborado pelo Departamento Nacional de Planeación (DNP). Segundo o seu texto

La Política Nacional de Seguridad y Convivencia Ciudadana (PNSCC) es el resultado de un proceso interinstitucional liderado por la Presidencia de la República, con la participación del Ministerio de Defensa Nacional, el Ministerio del Interior y de Justicia, la Policía Nacional y el Departamento Nacional de Planeación, y el concurso de otras entidades del orden nacional y del nivel territorial. (p. 01)

\footnotetext{
${ }^{19} \mathrm{O}$ documento completo pode ser acessado na página http://wsp.presidencia.gov.co/SeguridadCiudadana/consejeria/Documents/Pol\%C3\%ADtica\%20Nacional\%20de\%20Seguridad\%20y\%20Convivencia\% 20Ciudadana-\%20Espa\%C3\%B1ol.pdf
} 
Por sua própria definição, a PNSCC foi elaborada de maneira a comtemplar distintos setores governamentais que estariam comprometidos com as temáticas de segurança e justiça. Esse desenho de política pública circunscreve a temática da segurança e convivência cidadãs em um contexto múltiplo no que se refere ao cumprimento de responsabilidades, de forma compartilhada, já que cada ator envolvido possui responsabilidades específicas. Na Política Nacional, são estruturantes os conceitos de seguridad ciudadana ${ }^{20}$ e convivencia ciudadana, definidos, respectivamente, como

\begin{abstract}
La protección universal a los ciudadanos frente a aquellos delitos y contravenciones que afecten su dignidad, su seguridad personal y la de sus bienes, y frente al temor a la inseguridad. La convivencia, por su parte, comprende la promoción del apego y la adhesión de los ciudadanos a una cultura ciudadana basada en el respeto a la ley, a los demás y a unas normas básicas de comportamiento y de convivencia social. (p. 0102)
\end{abstract}

Por ser a república colombiana um Estado Unitário, com regime de governo presidencialista, a adesão à PNSCC ocorre na esfera nacional com os setores públicos envolvidos na sua execução. A Policía Nacional de Colombia (PONAL), igualmente, exerce suas funções em todo o território colombiano, e, por consequência, a parcela que lhe compete da PNSCC será desenvolvida nacionalmente.

\footnotetext{
${ }^{20}$ Os conceito de seguridad e convivencia ciudadanas adotados pela PONAL se encontram na publicação intitulada Estrategia de la Policía Nacional para la Consolidación de la Seguridad Ciudadana, disponível no link http://webcache.googleusercontent.com/search?q=cache:4w5f8R9j7mAJ:www.policia.edu.co/documentos/tomos tomos uribe/TOMO\%2520II\%2520Politica\%2520Estrategica\%2520Operacional.pdf $+\& \mathrm{~cd}=3 \& \mathrm{hl}=\mathrm{es} \& \mathrm{ct}=\mathrm{clnk} \&$ $\mathrm{gl}=\mathrm{co}$
} 
Na PNSCC, se faz distinção entre segurança cidadã e segurança nacional, a saber:

\section{Quadro 2: Comparação entre os paradigmas de seguridad ciudadana e seguridad}

\section{nacional}

\begin{tabular}{|c|c|c|c|}
\hline \multirow[b]{2}{*}{$\begin{array}{l}\text { Seguridad ciudadana } \\
\text { La protección universal frente a } \\
\text { los ciudadanos frente a aquellos } \\
\text { delitos y contravenciones que } \\
\text { afectan su dignidad, su seguridad } \\
\text { personal, y la de sus bienes; y } \\
\text { frente al temor a la inseguridad }\end{array}$} & \multirow[b]{2}{*}{ 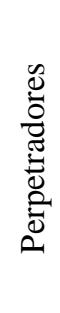 } & Área de seguridad ciudadana & \multirow{2}{*}{$\begin{array}{l}\text { Área de seguridad nacional } \\
\text { FARC, ELN, BACRIM }\end{array}$} \\
\hline & & $\begin{array}{l}\text { Violencia espontanea; } \\
\text { delincuencia común; delincuencia } \\
\text { organizada; expresiones urbanas } \\
\text { de GAOML y BACRIM }\end{array}$ & \\
\hline \multirow{3}{*}{$\begin{array}{l}\quad \text { Convivencia ciudadana } \\
\text { Comprehende la promoción del } \\
\text { apego y adhesión a una cultura } \\
\text { ciudadana basada en el respeto a } \\
\text { la ley, a los demás, y a unas } \\
\text { normas básicas de } \\
\text { comportamiento y convivencia } \\
\text { social }\end{array}$} & 8 & $\begin{array}{l}\text { Seguridad } \\
\text { Homicidio y hurto } \\
\text { Convivencia }\end{array}$ & $\begin{array}{l}\text { Narcotráfico: cultivo de coca; } \\
\text { laboratorio; distribución y } \\
\text { venta }\end{array}$ \\
\hline & $\frac{0}{\infty}$ & $\begin{array}{l}\text { Lesiones comunes; muertes en } \\
\text { accidentes de transito } \\
\text { Otros de alto impacto } \\
\text { Micro extorsión y micro tráfico }\end{array}$ & $\begin{array}{lr}\text { Actos de } & \text { terrorismo; actos } \\
\text { subversivos; } & \text { homicidios } \\
\text { colectivos; } & \text { secuestro } \\
\text { extorsivo; } & \text { extorsión } \\
\text { organizada; } & \text { mina antipersonas. }\end{array}$ \\
\hline & 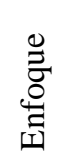 & Urbano/según categoría & Rural/zonas consolidación \\
\hline
\end{tabular}

Fonte: PNSCC, p. 02

Esse quadro apresenta as concepções de segurança cidadã e segurança nacional, que deveriam resultar na apresentação dos atores responsáveis por cada conjunto de iniciativas, alocadas segundo esses dois paradigmas. No entanto, não há no texto da PNSCC a menção de outra força pública a não ser a PONAL. Na estrutura do Ministerio de Defensa de Colombia, estão a Policía Nacional, e as forças armadas colombianas - Ejército, Armada y Fuerza Aérea. Esse fato permite ao ministério alocar, segundo a demanda, qualquer uma das quatro 
corporações para cumprir a agenda institucional. Contudo, a centralidade da PONAL nesta agenda se vê refletida nas inciativas da própria corporação.

A PONAL vem adotando os conceitos de seguridad e convivencia ciudadana em seu planejamento, com a elaboração de documentos norteadores e reguladores da ação policial, concebidos nesse marco. Dentre eles, se encontram Politicas, Lineamientos, Estrategias e Manuales voltados para a implementação da segurança cidadã. Cabe ressaltar que na Estrategia de la Policía Nacional para la Consolidación de la Seguridad Ciudadana - documento elaborado pela PONAL - se destaca que segurança cidadã se inspirou no conceito de segurança humana adotado pela ONU no informe PNUD de 1994. Outra referência citada é a publicação da FLACSO $(2002)^{21}$ dedicada ao debate da segurança cidadã na América Latina. Nesse sentido, é possível inferir que a PONAL buscou desde a década de $1990^{22}$ adotar os conceitos de segurança e convivência cidadã, antes da implementação da PNSCC.

Em nível local, o comandante da unidade policial local, quando se trata de um município, ao alcalde municipal e, em nível departamental, ao gobernador. Nesse desenho de gestão pública, a polícia se vê diante da tarefa de conciliar e acatar às prioridades do comando central da PONAL e Ministério de Defesa na esfera nacional de governo, como também às autoridades locais. Sobre a gestão financeira das unidades de polícia, nos municípios e departamentos, a alcaldía e a gobernación participam da gestão financeira da polícia, assegurando-lhe recursos e outros tipos de apoio para a execução de suas funções, como veículos, equipamentos etc. No Programa Departamentos y Munícipios Seguros ${ }^{23}$ (DMS) está

\footnotetext{
${ }^{21}$ A publicação da FLACSO intitulada Seguridad ciudadana, ¿espejismo o realidad? pode ser acessada na página http://www.flacso.org.ec/docs/sfseguridadciudadana.pdf

${ }^{22}$ É preciso destacar que os documentos encontrados na página da PONAL não apresentam a data de criação, fato que dificulta a construção do avanço da instituição em termos de implementação de conceitos e políticas organi9zxacionais. Entretanto, segundo as referências utilizadas nas suas publicações e por meio de outras fontes de pesquisa, pode-se situar as iniciativas relativas à implementação da segurança e convivência cidadã desde dos anos 90. Os anos noventa se caracterizam pela fase inicial do processo de redução de homicídios na Colômbia, justificada pela mudança provocada pela política de seguridad y convivencia ciudadana.

${ }^{23} \mathrm{O}$ documento DMS se encontra disponível na página
} 
a regulação legal sobre a responsabilidade que cabe aos mesmos na gestão da política de convivencia y seguridad ciudadana.

Uma das iniciativas que caracterizam a atuação da PONAL é Plan Nacional de Vigilancia Comunitaria por Cuadrantes (PNVCC). A ideia central pela qual se destaca este plano, seria a presença de uma dupla de policiais por turno que se responsabilizam pela integralidade das ações desenvolvidas pela polícia. Desde o policiamento ou patrullaje até o controle de moradores, de comércios locais, cumprimentos de ordens legais de silencia como nos casos de casas noturnas, problemas de ordem social, sensibilização de moradores sobre temas específicos, e todas as atividade cotidianas que fazem parte do policiamento. Os patrulleros responsáveis pelo cuadrante possuem um celular divulgado na comunidade para que seja possível chamar-lhes com mais celeridade. O plano, assim, confere aos policiais responsabilidades adicionais, demandando-lhes mais conhecimento e aproximação da comunidade.

Segundo seu texto, o PNVCC seria, resumidamente

Es una estrategia operativa del servicio de Policía, orientada a asegurar las condiciones de seguridad y convivencia ciudadana, permitiendo la asignación de responsabilidades en área específica, potencializando el conocimiento y accionar policial, a través de un modelo integral de servicio de policía, soportado en herramientas tecnológicas y de gestión enmarcada en principios de calidad. El Plan Nacional de Vigilancia Comunitaria por Cuadrantes busca optimizar el servicio de policía a través del fortalecimiento del talento humano, la delimitación territorial, la asignación de responsabilidades y la distribución eficiente de los recursos, con el fin de contrarrestar causas y factores generadores de delitos y contravenciones, contribuyendo al mantenimiento de la convivencia y seguridad ciudadana. (p. 38)

http://www.policia.gov.co/portal/page/portal/PROGRAMAS_DEPARTAMENTOS_MUNICIPIOS_SEGUROS/ $\underline{\text { Home }}$ 
Diante do processo de organização colombiano para lidar com as demandas de segurança, as frentes de trabalho se concentram em delitos ${ }^{24}$ comuns, como também nos crimes organizados como o narcotráfico. Outro ponto central para a PNSCC são as guerrilhas colombianas. A Colômbia se destaca no cenário regional por sua história de conflitos armados mobilizados por grupos de opositores políticos. Há inúmeras versões da origem do conflito armado colombiano. Dentre estas, há uma que indica que a formação político-partidária colombiana ocupou posição nodal para o desencadeamento do conflito.

La particularidad de Colombia surge de un hecho clave: los partidos Liberal y Conservador se forjaron antes de la consolidación del Estado y se constituyeron en actores centrales del proceso de imaginación e inculcación de una comunidad nacional, con sus redes multiclasistas de tipo clientelar, su papel de ejes articuladores entre las regiones y el centro, y sus movilizaciones fundadas tanto en las urnas como en las armas. (Contribución al entendimiento del conflicto armado en Colombia, 2015, p. 8,9)

Diferentemente dos países sul-americanos, a Colômbia manteve o modelo bipartidário - liberal e conservador - considerado um

(...) retroceso reformista, en un clima de aguda confrontación político-ideológica, se conjugó con la persistencia de un Estado débil y con unas instituciones militares muy precarias, que no habían podido alcanzar del todo una real autonomía frente a las pugnas partidistas y que no estaban en capacidad de garantizar un verdadero control del territorio y ni siquiera el monopolio de la violencia legítima. A esto se añade la alta politización partidista de la Policía Nacional, que reflejaba y reproducía en su interior las pugnas sectarias de los dos partidos tradicionales. (Contribución al entendimiento del conflicto armado en Colombia, 2015, p. 13)

\footnotetext{
${ }^{24}$ Nas estatísticas policiais colombianas, se adota delito como uma conduta punível de acordo com o Código Penal do país, a lei No 599/2000. Além de delitos, as contravenções também são consideradas condutas puníveis, que, porém, estão definidas no Código de Policía. Os delitos estão mais relacionados ao macro conceito de seguridad, enquanto que as contravenções se inserem no macro concepção de convivência. Nesse sentido, a policía lida com delitos e contravenções. No direito penal brasileiro, as infrações penais podem ser denominadas crime ou delitos, e contravenções, como no caso colombiano. As polícias brasileiras se fundamentam nessa legislação penal para a execução de suas atividades.
} 
A história colombiana, assim, registra um longo período de violências, homicídios, massacres. O legado de mais de meio século de guerrilha com as FARC-EP - um dos grupos da insurgência guerrilheira - inscreve a sociedade na cultura do medo, marcada pela impossibilidade da livre expressão e conformação político-ideológica, cujas principais bandeiras tinham a inclusão sócio-politica-financeira de setores de segmentos sociais alijados e excluídos ${ }^{25}$.

\begin{abstract}
Esse medo é, certamente, um dos efeitos da submissão prolongada à violência, sendo que a história da Colômbia, como república independente, caracteriza-se por não ter vivido períodos de cessar-fogo significativos ao longo de duzentos anos. Os colombianos transitam entre guerras e, por isso, o fato de ser, simultaneamente, "sobrevivente" e "guerreiro" ainda é um fundamento da identidade nacional e da "nação". (ÁLVAREZ, 2012, p. 03)
\end{abstract}

O conflito armado na Colômbia - segundo estudos ${ }^{26}$ - sofreu influência dos E.U.A. desde sua formação até atualidade. O impacto da influência (ou ingerência) é de difícil medição. No entanto, a Comisión Histórica del Conflicto y sus Víctimas, criada em 2014 na Mesa de Diálogo ${ }^{27}$ entre o governo colombiano e as FARC-EP para o promover o fim do conflito armado, de maneira contundente, sinaliza ao Estado colombiano, por meio do documento Contribución al entendimiento del conflicto armado en Colombia (2015), que

\footnotetext{
${ }^{25} \mathrm{O}$ conflito armado colombiano é deveras complexo, e, portanto, não pode ser apresentado de maneira simplista sem causar danos a sua compreensão. Nesse trabalho, a proposta é contextualizar o cenário de violências que co0nformam a realidade do país, porém, sem aprofundar sobre o tema. Para tal, recomenda-se a leitura de algumas obras: Contribución al entendimiento del conflicto armado en Colombia, 2015; Para reescribir el siglo XX. Memoria, insurgencia, paramilitarismo y narcotráfico (2011), de Javier Guerrero y Olga Acuña (compiladores); Quince años de Estado de Sitio en Colombia (1958-1978) [1979], de Gustavo Giraldo Gallón; La Guerra contra las FARC y la Guerra de las FARC, (2010), de Ariel Fernando Ávilla; El Papel de Estados Unidos en el Conflicto Armado Colombiano (2010), de Diego Otero Prada; Las Fuerzas Armadas en el Conflicto Colombiano (2002), de Alejo Vargas.

${ }^{26}$ Ver, La presencia de Estados Unidos en la formación de los militares colombianos a mediados del siglo XX (2011), de Adolfo Atehortúa; Colombia and the United States: the Making of an Inter-American Alliance, 19391960 (2008), de Bradley Lynn Coleman; Bases, Bullets and Ballots: The Effect of US Military Aid on Political Conflict in Colombia (2010), de Oeindrila Dube e Suresh Naidu.

${ }^{27} \mathrm{O}$ acordo elaborado pelo governo colombiano e as FARC-EP está disponível no link https://www.mesadeconversaciones.com.co/sites/default/files/AcuerdoGeneralTerminacionConflicto.pdf
} 
Estados Unidos es corresponsable directo en miles de asesinatos que han cometido las Fuerzas Armadas y los paramilitares, por su patrocinio a brigadas militares comprometidas en ese tipo de crímenes y por su respaldo a grupos privados de asesinos. (p. 54)

Para el conocimiento, reconstrucción y búsqueda de la verdad sobre la responsabilidad de Estados Unidos en el conflicto colombiano, así como de sus múltiples derivaciones y nexos con el Estado colombiano, sus Fuerzas Armadas, organismos de seguridad y empresarios privados, es indispensable que se desclasifiquen los documentos atinentes a Colombia que reposan en los archivos estadounidenses. (p. 55)

Para construir una sociedad en paz y democrática es indispensable replantear las relaciones entre Colombia y los Estados Unidos, de tal manera que se recupere la soberanía nacional con el objetivo de manejar en forma autónoma nuestros asuntos y que las políticas internas no se guíen ni por los intereses de Washington ni de ningún poder foráneo, sino que respondan a los intereses de la población colombiana. (p. 55).

Las Fuerzas Armadas en Colombia deben abandonar sus concepciones de contrainsurgencia, de anticomunismo y de enemigo interno, volver a sus cuarteles, reducir su tamaño y presupuesto y dedicarse a resguardar las fronteras nacionales. Esto implica una desmilitarización de la sociedad colombiana, que posibilite que nuevas fuerzas sociales y políticas se organicen y se expresen libremente sin el temor a ser víctimas de la persecución y estigmatización desde doctrinas contrainsurgentes y/o de la seguridad nacional. (p. 56)

Assim, para uma parcela da sociedade colombiana, a relação entre Colômbia e E.U.A. é notadamente indesejada, pelas sequelas e ranhuras que deixam o conflito armado no país. Essa é uma questão importante para a PNSCC e para as iniciativas desenvolvidas pela PONAL para o enfrentamento à violência. Somando-se a isso, estão os crimes comuns, a violência urbana, e violência estatal perpetradas por seus agentes. No caso colombiano, a questão das execuções sumárias ou ejecuciones extrajudiciales ${ }^{28}$ ou falsos positivos são elementos-chave para a compreensão do contexto violento exacerbado por tais práticas. Na história do país, a força pública vem sendo responsabilizada por assassinatos de pessoas não envolvidas com o

\footnotetext{
${ }^{28}$ Sobre ejecuciones extrajudiciales, ver http://www.acnur.org/fileadmin/scripts/doc.php?file=fileadmin/Documentos/BDL/2001/1558

http://www.scielo.org.co/pdf/espe/v31n71/v31n71a4.pdf http://repository.urosario.edu.co/bitstream/handle/10336/11694/1019011716-2016.pdf?sequence=1 http://www.scielo.org.co/scielo.php?script=sci_arttext\&pid=S0121-47052009000100001\&lang=pt http://www.scielo.org.co/scielo.php?script=sci_arttext\&pid=S0120-48232012000100013\&lang=pt
} 
conflito armado, com o fim de aumentar a estatística oficial de combate à guerrilha produzindo mortes.

Medellín, a cidade onde a pesquisa com os patrulleros foi desenvolvida, ocupou posição de destaque durante os anos mais violentos da guerrilla, quando o Cartel de Medellín liderado por Pablo Escobar, dominava o tráfico de drogas no país. A violência sofrida na cidade foi um elemento motivador para a implementação de políticas de segurança, que até 2015 estava vigente o Plan Integral de Seguridad y Convivencia ${ }^{29}$ desenvolvido pela última gestão municipal. O muniicpio, no país, vem desenvolvendo políticas, planos e estratégias com diferentes enfoques para abordar a violência na cidade. Por esta razoa, é reconhecida como a cidade que mais investe recursos sobre este tema no país.

Em Medellín, os sujeitos da pesquisa foram os patrulleros da Estación de Policía San Javier, localizada na Comuna 13. Esta comuna, em 2015, contava com uma população de 138.063 (centro e trinta e oito mil e sessenta e três) habitantes ${ }^{30}$. A história da comuna é mantida na memória da população por momentos de conflitos violentos entre guerrilheiros e a força pública. De fato, a Comuna 13 foi considerada uma excepcionalidade em termos de atuação das guerrilhas. Em geral, os grupos de guerrilheiros utilizam zonas rurais e de selva para exercerem domínio territorial. Nesses espaços, o controle sobre a população local - em geral, reservas indígenas e territórios de população afrodescendente - e o uso do solo para plantação de coca são atividades desenvolvidas com menor risco, devido às difíceis e numerosas rotas de fuga.

\footnotetext{
${ }^{29}$ O Plan Integral de Seguridad y Convivencia esta disponível na página https://www.medellin.gov.co/irj/go/km/docs/wpccontent/Sites/Subportal\%20del\%20Ciudadano/Convivencia\%2 0y\%20seguridad/Secciones/Plantillas\%20Gen\%C3\%A9ricas/Contenidos/2013/PISC/Documentos/Plan\%20Integ ral\%20de\%20Seguridad\%20y\%20Convivencia/Plan\%20Integral\%20de\%20Seguridad\%20y\%20Convivencia.pd $\underline{\mathrm{f}}$

${ }^{\frac{1}{0}} \mathrm{O}$ perfil demográfico da Comuna 13 pode ser acessado no link https://www.medellin.gov.co/irj/go/km/docs/wpccontent/Sites/Subportal\%20del\%20Ciudadano/Planeaci\%C3\% B3n\%20Municipal/Secciones/Indicadores\%20y\%20Estad\%C3\%ADsticas/Documentos/Proyecciones\%20de\%20 poblaci\%C3\%B3n\%202005\%20-\%202015/Perfil\%20Demografico\%202005-2015\%20Comuna\%2013.pdf
} 
A Comuna $13^{31}$, no entanto, foi considerada um território de guerrilha urbana. "Las milicias de las FARC [Fuerzas Armadas Revolucionaria de Colombia], del ELN [Ejército de Liberación Nacional] y de los CAP [Comandos Armados del Pueblo], controlaron a sangre y fuego esta comuna por más de diez años" (RENDÓN, 2007, p. 12). A partir de 2000, a violência na comuna se agravou em razão do acirramento da disputa entre os grupos armados pelo domínio do território.

O território dessa comuna guarda características geográficas que o destacam em termos de importância no que se refere a controle territorial. Segundo Aricapa,

\begin{abstract}
El dominio militar que los milicianos habían establecidos en la Comuna 13 empezaba, como todo dominio militar, por el control de las partes altas; en este caso las zonas rurales de los corregimientos San Cristóbal y AltaVista. Desde ahí controlaban las rutas de acceso a los barrios próximos, pero también el corredor natural entre el Valle de Aburrá y el rio Cauca en el occidente del departamento, zona cruzada en sus entrañas por el mayor proyecto vial de Antioquia en mucho tiempo: el Túnel de Occidente. Además, zona de importancia para futuros desarrollos urbanos de Medellín. Hacia el sur los milicianos también controlaban las dos únicas vías de acceso a Vila Laura, Betania, Belencito y El Corazón, y dominaban la cuchilla de la colina adyacente conocida como La Torre, un punto tan estratégico que quien no lo controlara no podía decir que tenía dominio completo de la comuna; de ahí que durante la guerra fuera un enclave arduamente disputado. Para la parte baja, hacia San Javier, controlaban las dos arterias de ingreso a los barrios Veinte de Julio, Las Independencias, Nuevo Conquistadores, El Salado, Eduardo Santos y Antonio Nariño. Y también eran suyas las vías de acceso a los barrios Metropolitano, Juan XXIII, La Quiebra, La Divisa, y La Gabriela, por el lado norte (ARICAPA, 2005, p.81).
\end{abstract}

\footnotetext{
${ }^{31}$ Nos links, a seguir, podem ser encontrados estudos que contam com mais profundidade aspectos do conflito armado experimentado pelas suas comunidades, desde perspectivas antropológicas, históricas e sociológicas. Há também um relatório do ACNUR sobre desplazamiento forzado chamado "Tendencias Globales

Desplazamiento. Forzado en 2015: Forzados a Huir". Segundo esse relatório, a Colômbia ocupou a décima posição no ranking mundial de países-origem, com um total de 340.200 refugiados.

http://www.acnur.org/fileadmin/Documentos/Publicaciones/2016/10627.pdf?view=1

http://www.centrodememoriahistorica.gov.co/descargas/informes2011/informe comuna13 la huella_invisible de la guerra.pdf

http://www.coruniamericana.edu.co/publicaciones/ojs/index.php/pensamientoamericano/article/viewFile/60/56 http://www.redalyc.org/articulo.oa?id=82515354002

http://iep.udea.edu.co:8180/ADcomuna13/bitstream/123456789/49/1/Quiceno_etal.pdf

http://www.redalyc.org/articulo.oa?id=85112936006
} 
Com o objetivo de expulsar os grupos armados, em outubro de 2002, o governo colombiano iniciou a Operación Orión - considerada a maior operação militar realizada no país, até então. Para a população local, as sequelas dessa operação continuam presentes na comuna, como pode ser atestado seja por meio dos relatos de moradores, seja concretamente em um local da comuna chamado Escombrera, no qual se acredita ser um cemitério clandestino dos mortos não contabilizados pela ação. A Operación Orión foi considerada um marco de efetividade da ação militar por parte de alguns, enquanto outros defendem a perspectiva desse mesmo episódio configurar o símbolo da violência estatal.

Após a operação, foram desenvolvidas iniciativas de seguridad ciudadana e convivencia pacifica pelos governos local e nacional. Atualmente, a violência extrema não faz parte da realidade local, mesmo que, para alguns, a comuna seria representada como "un leon dormido" (patrullero). Segundo a análise estatística produzida pela Ponal $^{32}$, o crime de maior impacto social - o homicídio - tem assumido o seguinte comportamento:

\section{Quadro 3: Número dehomicídios na Comuna 13}

\begin{tabular}{|c|c|c|c|c|c|c|c|c|c|c|c|c|}
\hline & 2003 & 2004 & 2005 & 2006 & 2007 & 2008 & 2009 & 2010 & 2011 & 2012 & 2013 & 2014 \\
\hline $\overrightarrow{0}$ & 77 & 37 & 36 & 41 & 48 & 67 & 115 & 191 & 210 & 178 & 125 & 64 \\
\hline
\end{tabular}

Fonte: PONAL

Em 2014, notou-se uma redução significativa no montante de homicídios, o que pode significar uma tendência. No entanto, para tal conclusão, é preciso acompanhar o comportamento dos números nos anos seguintes.

\footnotetext{
${ }^{32}$ A estatística completa de delitos está nos Anexos VII e VIII.
} 
Em 2010, o Programa CI2 ${ }^{33}$ (Centro Integrado de Intervención) foi implementado na Comuna 13. A principal meta do programa era enfrentar os grandes problemas da comuna, definidos como:

\footnotetext{
Homicidios, Lesiones personales, Extorsiones, Pago de Vacunas, Desplazamiento Forzado e Intraurbano, Confrontaciones entre Grupos Delincuenciales, Problemas Sociales surgidos de la proliferación de barrios subnormales, herencia de narcotráfico, guerrilla y autodefensas (p.02)
}

O programa reúne órgãos e serviços públicos dos setores de segurança, justiça e social. A Ponal, representada localmente pela Estación San Javier, faz parte do programa desenvolvendo ações específicas de polícia.

A Comuna 13 responde a uma subdivisão territorial que distribui o território em parte alta - que é formada pelos bairros mais empobrecidos - e a parte baixa - cuja características dos imóveis e vizinhança são superiores quando comparada com a vizinhança do plano mais elevado. Os serviços de transporte público alcançam cobrir quase a totalidade da geografia comunitária, seja por meio de ônibus ou de teleférico. As ruas são transitáveis em boa parte da comuna, e a população também conta com escada rolante em um setor especifico devido ao terreno em acentuado declive, que impossibilita o acesso de transporte público.

Nos trechos mais íngremes, longas escadarias cortam as casas amontoadas em lotes pequenos, sem espaços livres entre si. A maior parte das construções é de alvenaria, à exceção de alguns trechos na parte mais elevada da comuna, onde há construções de madeira e materiais e outros materiais. Um traço peculiar da Comuna 13 é a organização do espaço público e do espaço externo das casas. A impressão de limpeza e cuidado marcam a vizinhança, pois ao circular pelo território, chamam atenção a pintura das fechadas, a ornamentação com flores em algumas casas e no geral um aspecto de uma vizinhança cuidada. Não se vê lixo pelas ruas, nem

\footnotetext{
${ }^{33}$ Para maior conhecimento sobre o Programa CI2, ver Anexo II.
} 
objetos domésticos descartados. Outro aspecto marcante na comuna é a presença de imagens devocionais em quase todas as quadras. A cada dois ou três quadras, pode-se deparar com imagens de Jesus Cristo e da Virgem Maria, protegidos por pequenos santuários, muitas vezes. Os inúmeros santuários públicos são igualmente preservados e decorados com flores, e, em alguns casos, com velas.

Essas e outras características, que conformam o espaço público da Comuna 13, são associadas aos valores da cultura cidadã, pela comunidade. O cuidado dos espaços públicos, do entorno de cada residência, são qualidades da convivência pacífica, segundo a percepção comunitária, que incidem sobre o sentimento de pertencimento, e de valorização da vida comunitária. Evidentemente, há problemas e queixas, como perturbação por equipamentos de som ligados com volume excessivo e em horários de silencio, brigas entre vizinhos, violências diversas, e crimes, relatados por policiais e moradores. No entanto, cabe registrar que a impressão gerada pelo cuidado e asseio produz uma visão agradável aos olhos de pessoas que conhecem a comuna.

\subsection{CAMINHOS PARA SE CHEgAR A UM FIM}

Os caminhos escolhidos refletem a maneira com a qual se apreende a realidade pesquisada. Nesse sentido, o trabalho foi desenvolvido por meio de técnicas de pesquisa qualitativa, à medida que o interesse central era captar a perspectiva assumida pelos policiais das duas polícias em seus relatos. E, a partir de suas narrativas, construir as percepções desses sujeitos sobre o processo decisório posto em prática no momento da ação policial. 
As instituições de trabalho dos interlocutores desta pesquisa foram a Polícia Militar do Rio de Janeiro (PMERJ) e a Policía Nacional de Colombia. A abrangência territorial dessas polícias difere uma da outra, pelo fato de a PMERJ ser uma polícia estadual, enquanto a Ponal é nacional. Ambas são polícias militarizadas, a despeito de a Ponal se intitular um corpo armado de natureza civil. Os valores centrais da doutrina militar - hierarquia e disciplina - conformam o modus operandi das duas polícias. Como o foco da pesquisa é a ação de polícia, grosso modo a distinção da abrangência territorial não interferiu no resultado, pois, em ambas as realidades, os policiais realizam o trabalho de policiamento, ou patrullaje, nas ruas.

A entrada no campo na Colômbia foi facilitada pelo Professor Farid Samir Beñavides Vañegas da Universidad de los Andes (Uniandes), localizada em Bogotá. Por seu intermédio, foi possível estabelecer uma rede de conhecimento com interlocutores policiais dos setores administrativos da polícia, que, por sua vez, articularam o processo de autorização da pesquisa e a minha inserção no campo. No Brasil, a partir de uma rede de conhecimentos construída durante os anos de trabalho com a PMERJ, igualmente foram concedidas a autorização e a entrada no campo. Apesar de distantes geograficamente, as duas polícias apresentam um funcionamento semelhante no que diz respeito às relações interpessoais. Na cultura carioca (e brasileira), as relações de conhecimento, muitas vezes, determinam o andamento das coisas. Segundo o dito popular, mais vale ter uma boa amizade do que dinheiro. Na PMERJ, assim funciona. Por meio de conhecimentos, afeições e empatia ${ }^{34}$, pode-se obter o aperto de mão imprescindível para uma determinada ação. Na Ponal, as relações de proximidade também operam em favor de quem se beneficia delas. Para lograr êxito, é preciso estabelecer interlocutores estrategicamente posicionados na hierarquia policial.

\footnotetext{
${ }^{34}$ A temática do lugar das relações interpessoais e de poder na cultura brasileira foi abordada por Robert DaMatta em algumas obras publicadas. Dentre elas, estão "Carnavais, malandros e heróis" (1981); "Conta de mentiroso: sete ensaios da antropologia brasileira" (1994).
} 
Como dito, a tomada de decisão nas ruas é o foco desta pesquisa. A temática escolhida encaminha ao recorte em termos de sujeitos da pesquisa, ou seja, os policiais e patrulleros encarregados pelo policiamento ostensivo. No Brasil, são as polícias militares possuem competência legal para o policiamento nas ruas. Na hierarquia policial militar, os praças são responsáveis pelas atividades de policiamento ostensivo. Por praça são compreendidos os soldados, cabos, sargentos e subtenentes. Entre esses, os soldados são os que realizam o trabalho de rua da polícia, majoritariamente. Os demais são alocados em atividades diversas, inclusive supervisão e macrogestão.

Na Colômbia, apesar de somente existir a Ponal, o trabalho de policiamento nas ruas se configura em uma das especialidades das atividades de polícia. Com isso, os policiais de nível executivo são os que realizam a patrullaje. Na hierarquia na Policía Nacional, consideram-se policiais de nível executivo: comissário, subcomissário, intendente chefe, intendente, subintendente e patrullero. Todos esses escalões estão autorizados a realizar o trabalho de polícia nas ruas. No entanto, o patrullero é quem se dedica massivamente à função de patrulhamento. Por essas especificidades, os sujeitos privilegiados nesta pesquisa foram soldados e cabos da polícia militar, bem como patrulleros colombianos.

Dessa forma, em seguida a introdução dos assuntos abordados nesse trabalho, os seguintes capítulos foram elaborados para comtemplar: a metodologia - capítulo 2 - com o objetivo de apresentar os passos metodológicos para a realização da pesquisa, incluindo estratégias de entrada no campo e instrumentos utilizados, a construção da comparação entre os dois países - Brasil e Colômbia. No capítulo 3 - Percurso de entrada nos campos de pesquisa - em cada um dos países foram apresentadas as estratégias de definição dos territórios de pesquisa, como também, os critérios de definição das unidades policiais no Rio de Janeiro e em Medellín. Nesse capítulo também, estão os perfis dos sujeitos da pesquisa em ambas as polícias. O referencial teórico que sustenta a pesquisa foi apresentado no capítulo 4 . O capítulo 5 - As 
Polícias - abre a discussão sobre o cerne desse trabalho, que é a tomada de decisão nas ruas. Neste, também, se encontram a introdução das instituições policiais nos dois países - PMERJ e PONAL, tratando de sua estrutura organizacional, características culturais e documentos base para a ação policial em cada país. O capítulo 6 - Percepções sobre o trabalho de polícia - se concentra nos aspectos da ação de polícia, nas duas polícias, bem como debate o mandato policial. Neste capítulo, foram apresentadas a leitura que os sujeitos da pesquisa fazem acerca do processo decisório que lançam mão no seu cotidiano laboral. O capítulo 7 - Considerações Finais - estão as reflexões resultantes da pesquisa, onde foi construído uma análise do conteúdo desse trabalho. 


\section{METODOLOGIA}

\subsection{A PESQUISA}

A pesquisa centrou-se na ação de policiais que atuavam no morro Santa Marta (Rio de Janeiro) e na Comuna 13 (Medellín), mais precisamente na tomada de decisão no transcurso da prática policial cotidiana, no varejo da segurança pública. Nesse sentido, o foco foi o policiamento ostensivo, ou seja, a ação policial nos espaços públicos, a qual coloca sociedade e policiais (e a corporação e o Estado, por consequência) em contato direto e permanente. Os sujeitos da pesquisa foram policiais da Polícia Militar do Rio de Janeiro e da Policía Nacional de Colombia. A despeito da abrangência nacional da polícia colombiana e da delimitação estadual da PM, a comparação foi possível porque se sustentou na ação de polícia ostensiva, que, por usa vez, é executada por ambas as instituições.

Em termos de recorte geográfico, a atuação desses profissionais foi investigada em Medellín e no Rio de Janeiro. A cidade do Rio de Janeiro tem sido um cenário privilegiado de estudos, pesquisas e trabalhos científicos sobre a polícia por algumas décadas, fato este que proporcionou uma base bibliográfica relevante. A realidade de violências e violações de direitos também cometida por policiais transformou a cidade em um laboratório de pesquisa no campo de estudos de segurança pública e de polícia. Na Colômbia, o tema polícia não tem sido devidamente estudado pela academia, segundo o levantamento realizado no momento da pesquisa. Há uma produção científica considerável sobre os assuntos relacionados à seguridad ciudadana, justificado pela implementação de políticas de segurança pública ou ciudadana nas últimas décadas nas principais cidades colombianas, porém mais contundente em Bogotá, Cali e Medellín. 
Em Medellín, realizaram-se múltiplas iniciativas de segurança pública, como em nenhuma outra cidade no país. A cidade, entre as décadas de 70 até fins de 90 , experimentou um conturbado período de violências e atos terroristas resultantes da guerrilla colombiana, associada ao incremento do narcotráfico e ao aumento do número de bandas delincuenciales, que disputavam o monopólio do território. Esse contexto mobilizou ações e medidas do governo nacional para produzir políticas de seguridad que se somam a investimentos no campo do urbanismo ${ }^{35}$, que, até a atualidade, têm inspirado outras cidades colombianas. A repercussão do caso Medellín igualmente chamou a atenção de acadêmicos e gestores públicos de outros lugares, inclusive do Rio de Janeiro, onde algumas vezes especialistas colombianos foram convidados para prestar consultoria em temas de segurança pública.

O projeto de teleférico desenvolvido no Morro do Alemão foi inspirado na experiência do metrocable de Medellín, o qual faz parte do sistema integrado metro-bus-metrocabletransvia. Rio de Janeiro e Medellín são cidades latino-americanas que se destacam na região. Medellín pelos investimentos em segurança pública associados a política de urbanismo; Rio de Janeiro, por sua vez, como uma cidade onde a violência ocupa uma parte considerável da atenção popular e dos governos locais, como também pela implementação de estratégias no campo da segurança pública, cuja versão última teve um impacto positivo na redução da violência nas favelas cariocas: a UPP (Unidade de Polícia Pacificadora).

\subsection{A COMPARAÇÃo}

\footnotetext{
${ }^{35}$ Em julho de 2016, a prefeitura de Medellín recebeu o prêmio Nobel de cidades, resultante de investimentos nos últimos 20 anos na transformação do espaço público. Veja a notícia na página.

https://www.medellin.gov.co/irj/portal/nmedellin?NavigationTarget=navurl://89425903c12dca4dea6cdb8918639 $\underline{674}$
} 
Para se estabelecer uma comparação, faz-se necessário apontar características do que se está cotejando. Nesse caso, tratando-se de um trabalho comparativo entre dois países, outros estudos (COSTA, 2004, 2008; KANT DE LIMA, 2010) já vêm sendo elaborados com base nesse tipo de análise, os quais oferecem pistas claras no caminho metodológico a ser seguido. Nesse sentido, Brasil e Colômbia têm números elevados de homicídios por arma de fogo cometidos no espaço público, que estão relacionados com narcotráfico, crime organizado e brigas de gangues, segundo dados do Estudo Global sobre Homicídios lançado pela ONU em 2011, dispostos na tabela abaixo.

\section{Quadro 4: taxas de homicídios da America do Sul}

\begin{tabular}{|l|c|}
\hline \multicolumn{1}{|c|}{ País } & Taxa de homicídios \% \\
\hline Peru & 4,5 \\
\hline Argentina & 5,0 \\
\hline Chile & 5.0 \\
\hline Uruguai & 5,0 \\
\hline Bolívia & 6,0 \\
\hline Suriname & 7,0 \\
\hline Guiana Francesa & 10,0 \\
\hline Equador & 19,0 \\
\hline Guiana & 19,0 \\
\hline Paraguai & 23,5 \\
\hline Brasil & 25,0 \\
\hline
\end{tabular}




\begin{tabular}{|l|c|}
\hline Colômbia & 38,0 \\
\hline Venezuela & 41,0 \\
\hline
\end{tabular}

Fonte: Estudo Global sobre Homicídios, ONU/2011.

Para este estudo, a região da América do Sul está conformada pelos países elencados. Entre esses, Venezuela, Colômbia e Brasil ocupam as três primeiras posições em número de homicídios (todos os tipos de homicídios, incluindo por arma de fogo), nessa ordem. O quantitativo de homicídios constitui um dado importante a ser considerado no caso de um estudo sobre a atuação de polícia, já que as políticas de segurança pública são desenvolvidas com base no perfil criminal da população em questão (ou pelo menos deveriam). Mesmo ciente que outros crimes também são foco de atenção dos governos e das polícias, o homicídio é o de maior impacto social e político, ainda mais quando intencional.

As agendas de fomento de desenvolvimento estabelecem suas prioridades em termos de investimentos, considerando-se as taxas de homicídio de um país, entre outros dados. O planejamento da ação de polícia deveria, da mesma forma, ser elaborado a partir de um diagnóstico da criminalidade presente no território, mas não apenas seguindo esse parâmetro. Os estudos já revelaram que o trabalho policial, em grande medida, dedica-se também a casos de natureza não criminal, como conflitos interpessoais e desordens que fazem parte da vida em sociedade. Nesse sentido, tanto os crimes quanto os casos não criminais deveriam orientar a atuação de polícia.

No último Estudo Global sobre Homicídios (2013), foi apontado que, nas Américas, $66 \%$ dos homicídios são cometidos com arma de fogo, sendo que, na América do Sul, as taxas de homicídios por 100 mil habitantes colocam a Venezuela em primeiro lugar com 53.0, seguida da Colômbia com 30.8, Brasil com 25.2, Uruguai com 7.9 e Chile com 3.1. A arma de fogo 
como principal causa de homicídios revela que as mortes são resultantes de conflitos, os quais, segundo a realidade enfrentada nas cidades, infere-se que estão relacionados com confrontos com a força pública, entre grupos armados e, no caso colombiano, também com a guerrilla. Comparando-se os números apresentados em ambas as pesquisas, nota-se que no Brasil houve uma redução no número de homicídios, enquanto na Colômbia atestou-se um aumento. Os dois países inverteram suas posições, porem continuam com quantitativos próximos.

Cabe destacar que, para fins desta pesquisa, não foi procedida uma avaliação extensa e aprofundada das curvas criminais históricas nos dois países investigados, porém fez-se necessária uma breve apresentação desses dados, com o propósito de proporcionar uma visão mais abrangente, ainda que superficial, das realidades que compõem o cenário da prática policial. Deve-se destacar que, na América Latina, não somente pela violência, mas como também pela resposta governamental às diversas formas de violência e a resposta governamental, tanto o Brasil como a Colômbia se destacam pelas iniciativas que buscam aprimorar a atuação policial e aumentar a capacidade de resposta governamental.

Para além das estatísticas criminais, a contextualização da realidade desses países igualmente pode ser ampliada, observando-se algumas características expostas, a seguir:

\section{Quadro 5: Algumas caracterísitcas para comparação entre Brasil e Colômbia}

\begin{tabular}{l|l|l} 
& \multicolumn{1}{|c|}{ Brasil } & \multicolumn{1}{c}{ Colômbia } \\
\hline $\begin{array}{l}\text { Regime de } \\
\text { governo }\end{array}$ & República Federativa Presidencialista & $\begin{array}{l}\text { República, com regime de governo } \\
\text { presidencialista, de Estado Unitário }\end{array}$ \\
\hline População & 200 milhões & 46 milhões
\end{tabular}




\begin{tabular}{|c|c|c|}
\hline $\begin{array}{l}\text { Divisão } \\
\text { político- } \\
\text { territorial }\end{array}$ & $\begin{array}{l}27 \text { unidades federativas ( } 26 \text { estados e } 1 \\
\text { distrito federal) e } 5.570 \text { municípios. }\end{array}$ & $\begin{array}{l}32 \text { departamentos, } \\
\text { municípios, } 5 \text { distritos }\end{array}$ \\
\hline Polícia & $\begin{array}{l}\text { Âmbito federal: Polícia Federal, Polícia } \\
\text { Rodoviária Federal; âmbito estadual: } \\
\text { Polícia Militar, Polícia Civil. Nos } \\
\text { municípios, as guardas municipais } \\
\text { exercem a atividade de policiamento } \\
\text { com algumas restrições e limitações e } \\
\text { ainda diversidade de funções segundo a } \\
\text { administração local. }\end{array}$ & Policía Nacional de Colombia \\
\hline $\begin{array}{l}\text { Gestão da } \\
\text { polícia }\end{array}$ & $\begin{array}{l}\text { As polícias estaduais estão } \\
\text { subordinadas aos governos locais; as } \\
\text { polícias federais ao Ministério da } \\
\text { Justiça; as guardas municipais ao } \\
\text { governo municipal. }\end{array}$ & $\begin{array}{l}\text { Está subordinada ao Ministerio de } \\
\text { Defensa Nacional, no entanto, nos } \\
\text { municípios, os prefeitos (alcaldes) } \\
\text { exercem a função de chefe local da } \\
\text { polícia, como também, destinam } \\
\text { recursos públicos para a manutenção } \\
\text { das unidades policiais. }\end{array}$ \\
\hline $\begin{array}{l}\text { Porte e uso } \\
\text { de arma de } \\
\text { fogo por } \\
\text { cidadãos } \\
\text { comuns }\end{array}$ & $\begin{array}{l}\text { Proibido no Brasil desde 2003, com o } \\
\text { Estatuto do Desarmamento. }\end{array}$ & $\begin{array}{l}\text { Proibidos em 2012, durante alguns } \\
\text { meses do ano, e em algumas } \\
\text { cidades. }\end{array}$ \\
\hline $\begin{array}{l}\text { Política de } \\
\text { segurança } \\
\text { Pública }\end{array}$ & 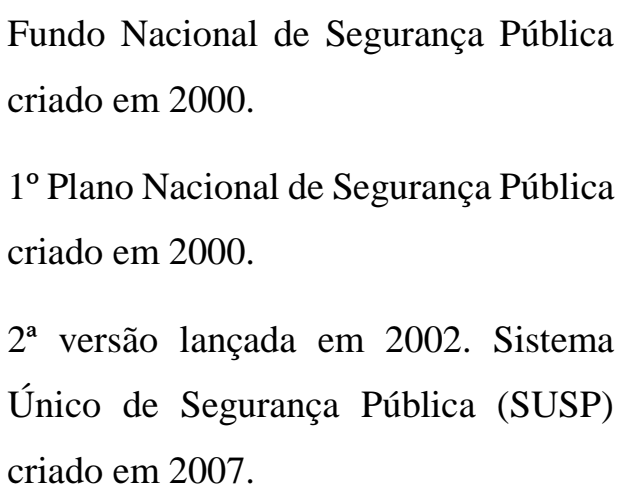 & $\begin{array}{l}\text { Plan Colombia (1999); Plan } \\
\text { Colombia II (2002). } \\
\text { Política de seguridad ciudadana e } \\
\text { Modelo nacional de vigilancia por } \\
\text { cuadrantes. }\end{array}$ \\
\hline
\end{tabular}




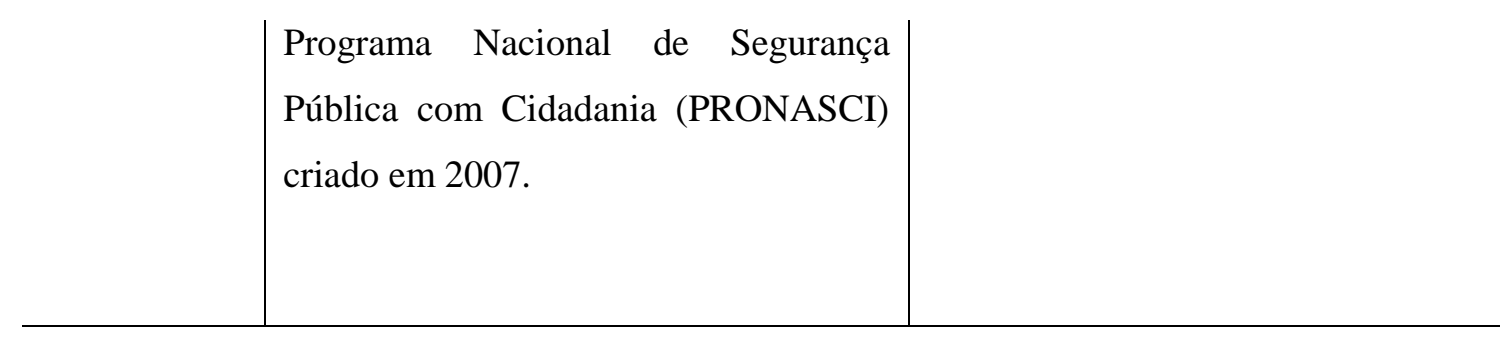

Fonte: Dados coletados em páginas oficiais de ambos os países.

Vale mencionar que o Plan Colombia não foi uma iniciativa voltada exclusivamente para os temas de segurança pública. Segundo estudos (NOVION, 2009; Ensayos críticos Plan Colombia), a elaboração deste plano foi marcada pela intervenção estadunidense na Colômbia com a perspectiva de implementar políticas de combate militar ao narcotráfico e ainda enfraquecer a oposição política colombiana.

El Plan tiene como objetivo central la acción militar para derrotar a la insurgencia colombiana, cuyo peso en la vida política del país y del continente ha crecido y se ha convertido en la experiencia más notable y casi única de la resistencia armada a la dominación imperial y a la "gobernabilidad" de las oligarquías locales y regionales. Este objetivo está unido a la política de Washington en las condiciones de la globalización y sobre todo del aumento del poder norteamericano en la balanza internacional, en un momento en que este poder en la esfera militar está por encima de su verdadero peso económico y comercial (NOVION, p. 460).

Além disso, pode-se destacar que a maior parte do orçamento oferecido pelos Estados Unidos foi dedicado às forças militares, segundo quadro abaixo:

Quadro 6: Orçamento dos E.U.A. para Colômbia

Rubrica orçamentária

Assistência militar

Assistência a polícia
Milhões de dólares

519.2

123.1 


\begin{tabular}{lc}
\hline Desenvolvimento alternativo & 68.5 \\
Desplazados & 37.5 \\
Direitos humanos & 51.0 \\
Reforma judicial & 13.0 \\
Estado de direito/fiscalía & 45.0 \\
Paz & 3,0 \\
& \\
& TOTAL \\
\hline
\end{tabular}

Fonte: Ensayos críticos Plan Colombia, Facultad de Derecho, Ciencias Políticas y Sociales de la Universidad Nacional de Colombia.

Grosso modo, ambos os países desenvolveram iniciativas no campo da segurança pública como respostas governamentais aos altos números de homicídios, aos conflitos armados, à percepção de insegurança e medo e, consequentemente, na redução da violência, por meio de planos nacionais, projetos locais e estratégias de prevenção à violência.

Entretanto, nesses países existem algumas distinções importantes. Uma das principais é a forma como as instituições policiais são geridas e estruturadas. Na Colômbia, a Policía Nacional de Colombia possui atribuições de polícia judiciária e de polícia ostensiva, com competência para atuar em todo território nacional, estando sob a estrutura do Ministerio de Defensa Nacional. A polícia colombiana é compreendida como uma polícia de ciclo completo, já que a mesma instituição realiza todas as atividades de polícia. Apesar de ter uma gestão própria e organizada, em última instância responde ao Ministério e, portanto, pode sofrer 
alterações de prioridades ou em qualquer outro aspecto de seu planejamento, caso assim seja determinado ministerialmente.

No Brasil, a política de segurança pública nacional orienta as políticas dos entes federativos, os quais, por sua vez, desenvolvem suas políticas locais a partir das diretrizes nacionais. Entretanto, sob o regime presidencialista de governo da república federativa, o pacto federativo brasileiro assegura a cada ente federado autonomia para organizar e normatizar o funcionamento de suas polícias ou órgãos de segurança pública e ainda optar por não seguir as diretrizes nacionais. Nos estados e no Distrito Federal, o trabalho policial se realiza em duas corporações distintas - Polícia Militar (polícia ostensiva) e Polícia Civil (polícia judiciária). Nos municípios, as Guardas Municipais têm incorporado algumas atribuições de polícia em sua prática. Em nível nacional, a Polícia Federal assume a função de investigação e repressão de crimes específicos. A função judiciária da polícia federal não entra em conflito com a polícia civil estadual justamente pela delimitação dos crimes de sua atuação. Existe ainda a Polícia Rodoviária Federal, cujo trabalho se concentra no policiamento em rodovias.

Os contextos brevemente apresentados se constituem como pano de fundo ou cenário onde o objeto da pesquisa - os elementos que conformam ou dão o contorno para a tomada de decisão dos policiais que atuam no policiamento ostensivo no morro Santa Marta (Rio de Janeiro) e na Comuna 13 (Medellín) - foi explorado, para compreender as dinâmicas sociais que contextualizam a prática policial.

\footnotetext{
Com efeito, você compreende o outro contra o pano de fundo da realidade circundante. Você vê um homem sacudindo as mãos loucamente. Você olha com mais atenção e vê algumas incômodas moscas voando ao redor dele. A ação desse homem se torna inteligível contra seu pano de fundo. As pessoas só podem ser compreendidas contra o pano de fundo de seu mundo (presumido). (TAYLOR, p.169)
}

Desse modo a realidade de cada país estudado também serve para evidenciar semelhanças e distinções entre essas nações. Brasil e Colômbia, a despeito de serem duas 
democracias, apresentam contextos com inegáveis diferenças, fator este que torna válida e legítima a opção metodológica de análise comparada. A comparação pode ser entendida como um recurso de relevância para produzir conhecimento sobre os contextos estudados, sobretudo porque permite avançar na "desnaturalização das rotinas, práticas e valores da própria sociedade, grupo ou instituição, a partir dos possíveis contrastes com outras sociedades, grupos ou instituições” (KANT DE LIMA, 2010, p.10).

O método comparativo, por natureza intrínseco ao campo da antropologia, vem sendo utilizado em estudos e pesquisas qualitativas de maneira a produzir os contrastes em que as cores do objeto em análise se tornam mais nítidas ou destacadas. Para Molino (2010), o contraste ou a comparação podem ser utilizados para três finalidades: i) entender - função cognoscitiva - as realidades pesquisadas; ii) para elaborar explicações sobre fenômenos definidos - função explicativa; iii) função aplicativa - para adotar localmente uma medida empregada para resolver um problema em outra realidade, desde que o problema seja o mesmo. Ainda que, para elaborar as funções da comparação, o autor tenha como referência estudos estatísticos, as finalidades apontadas por ele podem, igualmente, servir a pesquisas qualitativas.

De maneira sintética, a comparação pode ser empregada para analisar casos semelhantes (método da semelhança) ou para, a partir de casos distintos, identificar respostas adotadas (método da diferença). A escolha metodológica adotada nesta pesquisa tem como objetivo central identificar, compreender e explicar quais os mecanismos ou recursos utilizados pelos policiais das duas comunidades, anteriormente mencionadas, para tomar as decisões que necessitam no decorrer de suas atividades. Desse modo, a comparação realizada tomou como base a semelhança que se constituiu na observação do mesmo fenômeno junto a sujeitos com as funções semelhantes - policiais militares realizando policiamento ostensivo - em comunidades/realidades/contextos distintos. 
Os policiais que realizam atividades de gestão e de ensino também foram entrevistados como parte do processo de compreensão mais amplo do trabalho de polícia e da própria organização policial, sobretudo na Colômbia.

\subsection{ESTRATÉGIAS DE PESQUISA}

Como principal instrumento de pesquisa, foi adotado um roteiro semiestruturado de perguntas. A realização da observação do trabalho policial nas ruas complementou a pesquisa de campo, servindo para identificar as técnicas de abordagem que usavam seus equipamentos e armamento. O trabalho de campo, assim, foi desenvolvido por meio de observação participante, entendida a capacidade de ver o que é "insólito" no campo (DURAND, 2012, p.67), portanto, como elemento-chave para a apreensão da realidade observada. Nesse sentido, o olhar devidamente sensibilizado pela teoria (CARDOSO DE OLIVEIRA, 1998, p.19), possibilita observar e ver o que o campo apresenta. Complementado e aprofundando a coleta de dados, e considerando que "La elección de la técnica para la recogida de datos se ve muy condicionada por la naturaleza del problema" (RAGIN, 2007, p. 64), foram realizadas entrevistas em profundidade com roteiro semiestruturado, dado que o tema da pesquisa poderia ser apreendido a partir das percepções dos policiais entrevistados policiais sobre os mecanismos que empregam diante da demanda pela intervenção policial, nas unidades de polícia pesquisadas.

A pesquisa qualitativa permite ao pesquisador, por meios de técnicas pertinentes ao método, interagir com o universo que compõe o campo a ser pesquisado e, evidentemente, com os sujeitos desse universo. Sem dúvida, foi um exercício imprescindível para este trabalho. Entretanto, como em todo exercício, o resultado é imprevisível. Em um dia de pesquisa de campo, pode ocorrer qualquer coisa. O maior ensinamento do trabalho de campo é que o 
pesquisador deve preparar-se para o imprevisível, ou seja, o inesperado deve fazer parte do seu planejamento. Ainda que pareça contraditório, essa é a chave para um bom planejamento. Nesse sentido, Durand (2012) entende o método qualitativo como um tipo de arte, o que significa afirmar que as técnicas qualitativas se conformam por uma mistura de conhecimento, criatividade e capacidade de traduzir as percepções do fenômeno observado guardando sua estética. Em suas palavras:

\begin{abstract}
A través del tiempo y con el avance de la tecnología, los métodos cualitativos se vuelven más complejos; las técnicas, más sofisticadas, también complicadas. Sin embargo, el método científico en términos generales y la capacidad para investigar son, primero que nada, un oficio, una artesanía, un arte. (...) Pero sí se necesitan habilidades personales, ya que todo tipo de investigación requiere el involucramiento personal del investigador; sus recursos individuales para la observación y la sistematización; su capacidad para el análisis, la introspección y la reflexión; la única, personal y peculiar manera de conseguir, obtener, perseguir, procesar e interpretar la información (DURAND, 2012, p. 47-48).
\end{abstract}

A observação participante no campo se centrou tanto na forma como os policiais se relacionavam com seus colegas e superiores, quanto também no modo como reagiam a minha presença. Esse conjunto de informações coletadas em momentos e espaços distintos, com a presença de interlocutores diferentes ou mesmo à distância para garantir uma observação discreta, configurou uma base de dados qualitativos concreta e adequada para a análise almejada.

A entrevista em profundidade gravada em áudio com a devida autorização dos entrevistados se verificou estratégica, principalmente quando os sujeitos da pesquisa são profissionais que utilizam linguagem figurada e expressões emblemáticas para representarem suas ideias. Nesses casos, é relevante estar atento aos movimentos corporais, gestos, olhares, bem como mudanças de tom de voz reproduzidas nas falas. E, assim, a gravação da entrevista acaba também auxiliando o pesquisador nas anotações acerca dos aspectos mencionados, já que a resposta objetiva está sendo registrada. Igualmente relevante é a capacidade de criar empatia 
com o entrevistado, para que se consiga estabelecer uma relação de confiança entre ambos (LALANDA, 1998). Sem esses dois elementos, a entrevista pode não chegar ao resultado esperado. Evidentemente, essas condições variam em grau em cada caso.

Somando-se à base qualitativa, foram levantados documentos pertinentes à organização das polícias em termos administrativos, como organogramas, o quantitativo de policiais, as normas internas referentes ao policiamento, bem como demais materiais contendo diretrizes operacionais. Algumas estatísticas criminais foram incluídas na análise para servir como informações de contexto do cenário de violência.

\subsection{ROTEIRO DE ENTREVISTA}

As entrevistas foram realizadas por meio de um roteiro semiestruturado ${ }^{36}$ de perguntas, o qual permitiu alterações no seu conteúdo para explorar pontos relevantes surgidos durante as questões. O roteiro elaborado para a pesquisa na Colômbia foi utilizado no Brasil, depois de traduzido, sendo adaptado para contemplar algumas mudanças acerca dos entrevistados. Foram organizados em blocos temáticos de perguntas, primeiramente para estabelecer uma lógica de raciocínio que me permitisse memorizar os assuntos a serem abordados e fazer as perguntas de maneira leve, como em uma conversação. E também para já estabelecer os assuntos a serem abordados.

O primeiro bloco de perguntas foi de identificação do interlocutor. Em seguida, as perguntas do bloco "introdução", o qual servia como introdução real ao tema de segurança pública de maneira generalizada e, principalmente, como "quebra-gelo" para fazer com que o

\footnotetext{
${ }^{36}$ Os roteiros estão no Anexo I.
} 
entrevistado ficasse mais à vontade no espaço da entrevista. O bloco seguinte foi "o que fazem a polícia e o policial" e, por fim, o bloco "como faz".

Foram realizados dois grupos de discussão com policiais colombianos empregados em policiamento ostensivo. Vale destacar que a dinâmica de grupo utilizada para esses dois encontros tinha como finalidade criar um espaço informal, descontraído que possibilitasse um ambiente propício a uma conversa. Assim, diferentemente das técnicas empregadas em grupos focais ${ }^{37}$ que exigem o cumprimento de condições específicas segundo uma técnica própria, os grupos desenvolvidos buscavam fomentar o debate, a partir de um roteiro de perguntas utilizado como uma referência, permitindo adaptações necessárias. Principalmente, buscou-se garantir que as percepções dos participantes fossem recebidas sem críticas ou interferência por parte dos demais participantes nem por parte da facilitação, como também dar-lhes a oportunidade de expressar suas visões de maneira voluntária e livremente.

Os grupos de discussão foram organizados na Comuna 13, no terraço de um edifício onde estão alguns serviços públicos. O terraço, por ser ao ar livre, proporcionou privacidade e uma atmosfera agradável. Antes de começar, foi servido um lanche cujo objetivo também era colocar os participantes em contato, dado que não se conheciam, e assim facilitar a interação no grupo de discussão. Depois do lanche, eles foram convidados a sentar para começar o trabalho A seleção dos participantes do grupo foi aleatória. Já que nos dias marcados para os grupos, foram enviados os policiais disponíveis no momento, e nesse caso, nem a polícia poderia antecipar quem participaria devido à imprevisibilidade de eventos como licenças, ausências, dentre outras. Em cada grupo, participaram quinze policiais, sendo todos patrulleros.

\footnotetext{
${ }^{37}$ Para a realização de um grupo focal, é preciso ter um espaço preferencialmente com uma sala ao lado, na qual de possa acompanhar por meio de janela espelhada o grupo, sem que o grupo saiba. Além disso, a equipe deve ser formada por um facilitador e dois assistentes, cada um com um papel definido. Para mais informação sobre grupo focal, ver Focus Groups (Porta, 2014); Focus Groups: a practical guide for applied reaserch (Krueger \& Casey, 2015); Notas para o trabalho com a técnica de grupos focais (Kind, 2004).
} 
Para as entrevistas dos policiais gestores, e dos demais entrevistados, os roteiros foram criados segundo o perfil de cada um, mantendo como foco a atuação policial. 


\section{PERCURSO DE ENTRADA NOS CAMPOS DE PESQUISA}

\subsection{Colômbia}

O trabalho de campo na Colômbia transcorreu de março a julho de 2015, iniciando pela capital colombiana Bogotá, já que o país é uma república, com regime de governo presidencialista, de Estado unitário e que concentra toda a estrutura de gestão pública em sua capital. Na cidade, também se encontra a Universidade de los Andes (Uniandes), a qual eu estava vinculada devido ao meu orientador estrangeiro ser docente na instituição. Com isso, a pesquisa foi realizada em Bogotá e em Medellín, sendo a última, a cidade onde foi realizado o trabalho de campo com policiais ou, mais precisamente, com os patrulleros, que fazem o policiamento nas ruas.

Considerando o trabalho solitário de uma pesquisa desenvolvida no exterior, vale destacar que é essencial contar com a orientação, a qual representa o apoio necessário e imprescindível, já que "como en cualquier oficio, la práctica cotidiana y la sabia orientación de un maestro son fundamentales" (DURAND, 2012, p. 47). No entanto, o campo se apresenta dinâmico e demandante de respostas e de tomadas de decisão às vezes imediatas. E, nessas situações, a orientação somente poderia acontecer depois. Foram esses os momentos de maior tensão e preocupação. Um esforço máximo foi feito para evitar as situações nas quais seria necessário tomar uma posição e definir os rumos da pesquisa de imediato. Em algumas situações, isso foi possível, mas o campo é repleto dos "imponderáveis" malinowskianos, que são inadiáveis testes de domínio sobre o instrumento, o objetivo e a metodologia da pesquisa. Experiência em pesquisa, paciência e determinação constituem ferramentas que fazem a diferença para um pesquisador nessas condições. É preciso lembrar que o campo de pesquisa em instituições policiais (e de natureza militar) agrega às questões próprias de polícia as 
especificidades de uma organização militar. O campo de pesquisa polícia impõe inúmeras dificuldades (ANJOS, 2010; MINAYO, SOUZA \& CONSTANTINO, 2008; COSTA, 2004; MUNIZ, 1999), pois a aproximação com o mundo civil acadêmico é relativamente novo, entre outros fatores. "Até muito recentemente, nem historiadores nem cientistas sociais haviam reconhecido a existência da polícia, quanto mais o importante papel que desempenha na vida social” (BAYLEY, 2006, p. 15). Além disso, a organização burocratizada e fortemente hierarquizada conjugada à cultura policial e à aplicação irrestrita da característica do sigilo no manejo de informações conforma um cenário adverso que demanda estratégias de entrada no campo bem estudadas. Via de regra, é preciso partir de alguma rede mínima de conhecimento para traçar a trajetória da pesquisa. A experiência acumulada nesse campo no Brasil foi crucial, no entanto, outros desafios se apresentaram, como já previsto.

Com base nas interlocuções do meu orientador colombiano, foi possível identificar a porta de entrada no campo. Como no Brasil, a Ponal funciona na linha das relações interpessoais. Meu interlocutor inicial foi, então, um orientando do Prof. Farid. Nosso primeiro contato ocorreu de maneira informal em um restaurante próximo a Uniandes. Nesse encontro, o "caminho das pedras" para a aprovação de meu projeto de pesquisa e decorrente entrada na polícia foi traçado. Meu interlocutor indicou a seção de pesquisa da Escuela de Posgrados de Policía (ESPOL) como uma porta de entrada favorável e agendou uma reunião com essa equipe. A equipe de trabalho da ESPOL era formada por policiais e civis. Essa seção de pesquisa trabalha principalmente com o fortalecimento acadêmico dos policiais sob a perspectiva do intercâmbio de experiências e saberes entre polícias de diferentes países. Assim, meu trabalho se adequava aos objetivos dessa equipe. Antes desse encontro, tivemos outra reunião para que ele conhecera o projeto de pesquisa do meu trabalho na Colômbia. Nesse espaço, meu interlocutor fez contribuições muy importantes para a aprovação da pesquisa. Contou-me sobre a cultura institucional da ESPOL, que operava segundo uma lógica de contrapartidas da parte 
de quem está se beneficiando da instituição, ao realizar uma pesquisa na mesma. E, assim, acabou por me apresentar os possíveis produtos de escambo de interesse da escola.

Nessa reunião, apresentei o meu projeto aos membros da equipe, oferecendo-lhes a contrapartida sugerida anteriormente pelo meu interlocutor, que seriam artigos em conjunto com algum policial desta ou de outra secção ou elaborar um documento com recomendações derivadas dos resultados da pesquisa ou algum tipo de parceria acadêmica mais prolongada. Assim, cumprindo com as recomendações do meu interlocutor, recebi o aceite, mas não antes de passar por quatro reuniões.

Junto a essa equipe, conheci empiricamente a metodologia colombiana de pesquisa que é pensada e desenvolvida em conjunto com aqueles que são seus sujeitos. Trata-se de uma proposta metodológica chamada Investigación Acción Participación ${ }^{38}$ (IAP), que se configurou em uma difícil experiência, pois ao apresentar meu projeto de pesquisa já defendido e aprovado, vi-me diante de uma "nova banca". Essa equipe fez sugestões de alterações significativas, justificando-as com muita transparência e tranquilidade com base em suas próprias demandas por conhecimento. Percebi que parte das ansiosas demandas da ESPOL também era resultante do ineditismo desse tipo de pesquisa na própria polícia assim como na academia colombiana. Por fim, chegamos a um consenso por meio de um diálogo persuasivo, que não afetaria meu projeto inicial. Como esperado, esse processo levou semanas e, em seguida, comecei a fase da pesquisa sobre a gestão da polícia. Por ser uma organização nacional, junto aos comandos específicos da PONAL, foi necessário desenhar as estratégias de campo e cronograma de

\footnotetext{
${ }^{38}$ Segundo Hernandez (2015), essa abordagem assim é definida: "En cuanto a la investigación, se trata de un procedimiento reflexivo, sistemático, controlado y crítico que busca estudiar algún aspecto de la realidad, con una expresa finalidad práctica; acción, indica que la forma de realizar el estudio es ya un modo de intervención y que el propósito de la investigación está orientado a la acción, siendo ella a su vez fuente de conocimiento; y la participación es una actividad en cuyo proceso están involucrados tanto los investigadores como la misma población estudiada". Trata-se de uma abordagem recorrente nas pesquisas acadêmicas colombianas.
} 
atividades de pesquisa. Finalizada, então, a etapa em Bogotá, a ação seguinte foi iniciar a pesquisa em Medellín.

\subsubsection{SOBRE A DEFINIÇÃO DO TERRITÓRIO E FOCO DA PESQUISA}

Estando em Bogotá, o foco era compreender a estrutura de gestão da PONAL com o por meio da facilitação ao campo de meu interlocutor, buscando identificar quais seriam as unidades gestoras importantes para a minha pesquisa. A formação policial se configurou como o tema abre-alas, sobre o qual foram agendadas as primeiras visitas e entrevistas do trabalho de campo na cidade. a primeira unidade de formação visitada foi a Escuela de Posgrados Miguel Antonio Lleras (ESPOL) Pizarro, onde estive algumas vezes, inclusive para eventos. A equipe da Área de Investigación da Escuela foi a grande interlocutora para o acesso a ela e as demais unidades que havia selecionado. A Escuela conta com essa equipe especialmente dedicada à pesquisa $\mathrm{e}$ ao intercâmbio internacional, já que a pós-graduação busca a troca de conhecimento com polícias de outros países, assim como especialistas no tema segurança pública. Com a intermediação introdutória dessa equipe, consegui entrevistar a pedagoga da escola, além de dois majores pós-graduandos que tinham relação com a minha pesquisa. Entrevistei ainda o meu orientador colombiano, professor Farid Samir Beñavides. Por meio de ofícios da Escuela consegui entrar no campo - cumprindo, desse modo, a formalidade organizacional da polícia em Bogotá e em Medellín. Metaforicamente, a Escuela foi o meu "pé de cabra" na Ponal.

Em Medellín, o meu objetivo era o de entrevistar o público prioritário do projeto: os patrulleros. Antes, deveria definir o recorte territorial, ou seja, em qual comuna estaria 
observando a prática policial. Medellín se subdivide em comunas, que são áreas urbanas compostas por bairros, segundo o mapa ${ }^{39}$ a seguir indica:

Figura 1: Mapa territorial das comunas de Medellín.

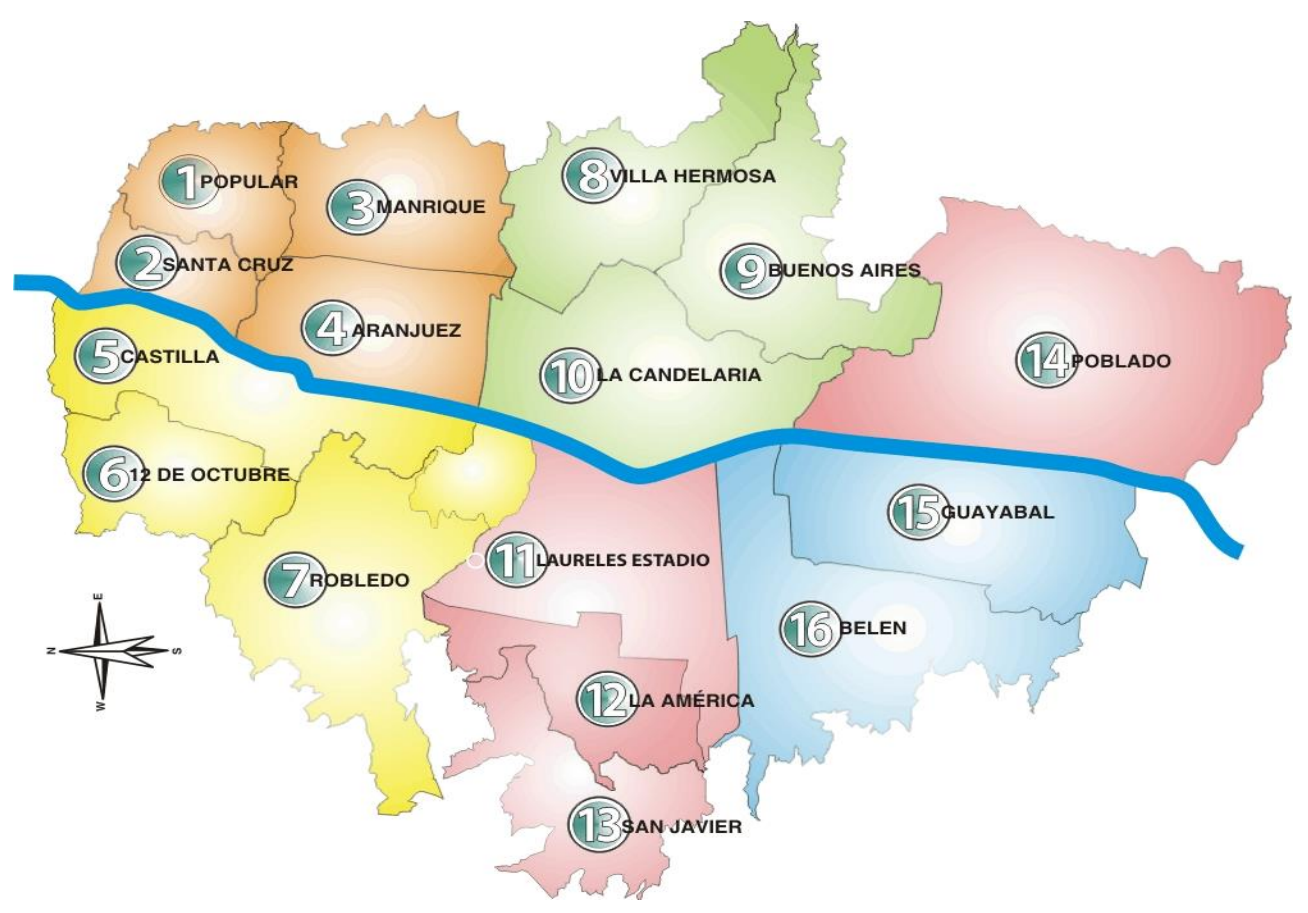

Fonte: Página oficial da Alcaldía de Medellín.

As comunas estão organizadas segundo um sistema classificatório complexo chamado "estrato", sem ainda, porém, uma fundamentação socialmente difundida. Os estratos mais baixos correspondem a áreas com moradias de baixo valor e condições mais precárias de vida;

\footnotetext{
${ }^{39}$ No link a seguir, o mapa pode ser acessado https://www.medellin.gov.co/irj/go/km/docs/wpccontent/Sites/Subportal\%20del\%20Ciudadano/Cultura/Seccion es/Mapas/Documentos/2010/Mapas\%20tur\%C3\%ADsticos/mapamedellin.jpg
} 
e os mais altos, o contrário. Para definir a comuna, levei em consideração as dinâmicas social e criminal presentes na cidade.

Fiz consultas a policiais e aos moradores com os quais tive contato, além de uma pesquisa em documentos sobre o perfil das comunas. A escolha do trabalho se centrou em uma comuna que apresentasse diversidade em termos de dinâmicas sociais e criminais, com bairros igualmente diversos. Seria um cenário plural adequado para observar a prática policial. Portanto, a escolhida foi a Comuna 13, justamente por contemplar os critérios estabelecidos. É ainda uma comuna emblemática, por ter sido realizada uma das investidas militares mais contundentes da história colombiana em espaços urbanos, a chamada Operación Orion. Também conta com um projeto-piloto intitulado CI2, que se traduz por Centro Integrado de Intervención. Trata-se de um projeto que reúne os serviços sociais oferecidos pela prefeitura e a polícia local, tendo por finalidade a redução da vulnerabilidade social e da criminalidade.

Definida a comuna, o passo seguinte foi conhecer e me apresentar ao Comando da Metropolitana del Valle de Aburrá (MEVAL) para apresentar meu projeto com o fim de organizar minha entrada no campo junto à polícia. O Valle de Aburrá é uma região, na qual está localizado o departamento de Antioquia. O Comando, então, é responsável pela gestão da ação policial nesta região. Com o MEVAL, foi obtida a autorização para a realização da minha pesquisa, que solicitou um cronograma detalhado do trabalho que seria desenvolvido, para garantir minha segurança durante o trabalho de campo, já que, segundo eles, a polícia estaria responsável por minha integridade.

O cronograma demandado deveria conter não apenas as entrevistas com os policiais, mas também quaisquer outras atividades na Comuna 13, pois, nesse caso, estaria acompanhada por policiais. Para mim, no entanto, fazer pesquisa de campo na comuna acompanhada por policiais, não seria positivo, pois inviabilizaria o meu trabalho. Conforme demandado, elaborei um cronograma detalhado. Os demais detalhes - como quantitativo de entrevistas, perfil dos 
entrevistados e documentos necessários sobre a Estación de Policía San Javier, responsável pelo policiamento na Comuna 13 - foi tratado diretamente com o comandante da unidade, em outra reunião.

No trabalho de campo na Estación, reuni-me com o comandante para tratar de todos os assuntos referentes à pesquisa, buscando, principalmente, elaborar as estratégias para a realização das entrevistas. Com o comandante, o objetivo era compreender como funcionava a o policiamento, no que diz respeito ao planejamento de ações, bem como a rotina diária dos policiais. Nesse período, de minha parte, todos os esforços foram empregados para apreender ao máximo (e rapidamente) o funcionamento dessa unidade, para propor um plano de trabalho que incluísse desde a mobilização dos policiais até os espaços a serem utilizados para as entrevistas. Todas as atividades teriam de acontecer na própria Comuna 13. Desse modo, foram definidos os espaços para cada atividade de pesquisa que faria. As entrevistas ocorreram na sede do Programa CI2, que ocupa o último de um prédio onde funciona a Casa de Justicia, no bairro Veinte de Julio. Nesse caminhar das coisas e do tempo, foi oferecido uma sala desocupada para fazer as entrevistas. Os policiais eram encaminhados diariamente a esse local, em geral chegando em duplas. Um dos policiais esperava do lado de fora, enquanto o outro era entrevistado.

No início, eles se perdiam no prédio, mas, depois de um curto tempo, os funcionários e, principalmente, os seguranças da portaria, já os encaminhava diretamente porque passaram a me conhecer. Os primeiros entrevistados não faziam ideia da razão porque estavam ali. Com o tempo, eles mesmos fizeram a divulgação interna, e os que chegavam perguntavam-me se eu era "a brasileira das entrevistas". O primeiro ponto que abordava, de modo introdutório, era a natureza do meu trabalho, demarcando e reforçando que não era vinculada à polícia, nem ao governo local. Apresentava a mim e a meu projeto por meio de minha trajetória acadêmica e fornecia, enfaticamente, as informações necessárias para comprovar meu o vínculo com a 
Academia, assim como a natureza científica do trabalho. Tomei todos os cuidados possíveis, atentando para o fato de esse estudo ser inédito, e ainda mais raro por ser realizado por uma brasileira. Apesar de estarem cumprindo uma ordem do comando, pedia-lhes autorização para iniciar a entrevista e a gravação. Sinalizei que somente eu teria acesso às gravações. De qualquer maneira, orientava-lhes a não mencionar, na entrevista, os próprios nomes nem os de seus colegas.

A despeito do ineditismo e da desconfiança característica dos policiais, com o desenrolar da entrevista, eles iam, aos poucos, saindo do padrão de resposta institucionais predeterminadas. Com algumas poucas exceções, podia perceber, em suas expressões faciais e corporais, interesse e sinceridade. A eles parecia muito interessante ter contato com uma estrangeira brasileira. Depois que desligava o gravador, muitos comentavam que queriam conhecer o Brasil e, sobretudo, a realidade carioca. Pediam para eu contar como estava a violência no Rio, bem como a resposta policial. Mencionavam filmes que assistiram sobre esse tema e que lhes impactaram tanto pela corrupção policial como pelo alto grau de violência nas ruas da cidade. Ao finalizar a entrevista, sempre perguntava se gostariam de receber uma síntese da pesquisa, obtendo, da maioria, resposta positiva.

Minha entrada na comuna foi facilitada por um misionero conhecido dos proprietários da guesthouse onde fiquei hospedada. Os misioneros são pessoas de natureza religiosa, dedicadas à vida comunitária a partir de uma perspectiva humanitária. São personagens comuns na cidade, que gozam de respeito e prestígio junto às comunidades mais pobres. E, por isso, adentrar com ele na comuna acabou por me colocar "acima de qualquer suspeita". Segundo o meu interlocutor religioso, ciente do meu propósito acadêmico, com ele eu seria recebida e não correria risco. Fiz algumas visitas com ele, podendo assegurar, desse modo, uma visão diferenciada da realidade sem a interferência advinda da presença de policiais. 


\subsubsection{Perfil dos entrevistados}

Os policiais escolhidos deveriam dispor de experiência de trabalho no Programa CI2 pelo fato de ser importante o acesso a esse tipo de percepção. Na reunião com o comanda da Estación San Javier, perguntaram-me qual seria o quantitativo de entrevistas que pretendia fazer, em um universo total de pouco mais de duzentos policiais. Tive de definir um número de imediato, até porque já sabia não conseguir explicar que preferiria seguir fazendo as entrevistas até que o campo se esgotasse. Esse tipo de abordagem é de difícil compreensão e assimilação para profissionais altamente pragmáticos e com um perfil de planejamento introjetado em seu modus operandi. Propus 40 (quarenta) entrevistas, e, imediatamente, o comandante adotou como definido que seria um de cada quadrante, já que a Comuna 13 contabiliza quarenta de quadrantes. Esse total não foi estabelecido com base em cálculos de amostragem ou qualquer outra fórmula estatística. Simplesmente um número apontado no calor da reunião.

Em seguida, propus fazer duas entrevistas pela manhã, que contemplaria o turno que começa às $8 \mathrm{~h}$, bem como mais duas com os policiais do turno da tarde, que se inicia às $15 \mathrm{~h}$. Optei por não realizar entrevistas no turno da noite, pois os policiais trabalham por uma escala chamada ciclo. Um ciclo equivale a um plantão em três turnos, em dias consecutivos, com intervalo de oito horas entre eles. Portanto, eles acabam adquirindo experiência de todos os turnos do dia. Da mesma forma, perguntaram-me quais dias da semana eu faria as entrevistas. Respondi-lhes que seria de segunda a sexta-feira. No fim da reunião, o comandante ordenou a seu assistente que garantisse que somente policiais "bons" fossem entrevistados, tentando evitar que eu abordasse policiais que "falam bobagens". Esse filtro poderia enviesar os resultados, o que provocou um sinal de alerta. Durante os dias subsequentes, consegui estabelecer uma relação de proximidade com o assistente do comandante, com ele conseguindo, assim, desfazer essa orientação. 
Solicitei um espaço para constituir um grupo de discussão, o qual poderia se viabilizar em um momento subsequente a uma aula ou reunião, podendo, desse modo, aproveitar o deslocamento realizado para esse fim. O comandante, então, marcou as datas com dois grupos, horário e local. Por fim, evidenciei o meu interesse de entrevistar alguns policiais nos três Centros de Atención Imediata (CAI) existentes na comuna, como também o de entrevistar a alguns policiais gestores. De uma maneira própria, e com a contundência de costume, o comandante autorizou essas outras entrevistas somente na segunda semana de trabalho de campo. Para finalizar a reunião, disse a seu assistente: "Da nossa parte, nada pode falhar no cronograma"; "é necessário criar um tipo de documento de confirmação de presença dos policiais nos dias e horários marcados para as entrevistas, que deve ser devolvido a mim, para que eu tenha certeza que tudo saiu como planejado".

Fiz as seguintes entrevistas com policiais: 38 (trinta e oito) com patrulleros - sendo quatro mulheres, três subintendentes, dois grupos de discussão com policiais de diversos graus hierárquicos do grupo de subordinados, além de duas com coordenadores pedagógicos da Escuela de Formación de Patrulleras uma com um policial do setor de direitos humanos e duas com o chefe de planificación. Abaixo apresento um quadro com informações dos policiais que constituem o público-alvo da pesquisa.

\section{Quadro 7: Perfil de patrulleros e intendentes}

\begin{tabular}{|l|l|l|l|l|l|l|}
\cline { 2 - 6 } \multicolumn{1}{|l}{} & Grau hierár & Sex & $\begin{array}{l}\text { Ida } \\
\text { de }\end{array}$ & $\begin{array}{l}\text { Tempo de } \\
\text { trabalho na } \\
\text { PONAL }\end{array}$ & $\begin{array}{l}\text { Tempo de } \\
\text { trabalho na } \\
\text { cidade }\end{array}$ & $\begin{array}{l}\text { Grau de } \\
\text { formação }\end{array}$ \\
\hline P1 & Patrullera & $\mathrm{F}$ & 24 & 2 anos & 8 meses & Ensino médio \\
\hline P2 & Patrullero & $\mathrm{M}$ & 24 & 1 ano & 1 ano & Ensino médio \\
\hline
\end{tabular}




\begin{tabular}{|c|c|c|c|c|c|c|}
\hline P3 & Patrullera & $\mathrm{F}$ & 23 & 2 anos & 1 ano e 3 meses & Ensino médio \\
\hline P4 & Patrullero & M & 30 & 6 anos & 2 anos & Ensino médio \\
\hline P5 & Patrullero & M & 24 & 3 anos & 3 anos & Ensino médio \\
\hline P6 & Patrullero & M & 31 & 9 anos & 5 anos & Ensino médio \\
\hline P7 & Patrullero & M & 22 & 3 anos & 1 ano e 3 meses & Ensino médio \\
\hline P8 & Patrullero & M & 22 & $\begin{array}{l}1 \text { ano e } 6 \\
\text { meses }\end{array}$ & 1 ano & $\begin{array}{l}\text { Superior } \\
\text { incompleto }\end{array}$ \\
\hline P9 & Patrullero & M & 25 & 3 anos & 3 anos & Ensino médio \\
\hline P10 & Patrullero & M & 27 & 7 anos & 7 anos & Ensino médio \\
\hline P11 & Patrullero & M & 27 & $\begin{array}{l}1 \text { ano e } 6 \\
\text { meses }\end{array}$ & 1 ano e 3 meses & \\
\hline P12 & Patrullero & M & 23 & $\begin{array}{l}1 \text { ano e } 4 \\
\text { meses }\end{array}$ & 1 ano e 4 meses & Ensino médio \\
\hline P13 & Patrullero & M & 21 & $\begin{array}{l}1 \text { anos } 6 \\
\text { meses }\end{array}$ & 6 meses & Ensino médio \\
\hline P14 & Patrullero & M & 22 & 1 ano & 1 ano & Ensino médio \\
\hline P15 & Patrullero & M & 21 & 2 anos & 2 anos & Ensino médio \\
\hline P16 & Patrullero & M & 37 & 13 anos & 13 anos & Ensino médio \\
\hline P17 & Patrullero & M & 20 & $\begin{array}{l}1 \text { ano e } 3 \\
\text { meses }\end{array}$ & 1 ano e 3 meses & Ensino médio \\
\hline P18 & Patrullero & M & 22 & 3 anos & 1 ano & Ensino médio \\
\hline P19 & Patrullero & M & 22 & $\begin{array}{l}1 \text { ano e } 5 \\
\text { meses }\end{array}$ & 1 ano e 5 meses & Ensino médio \\
\hline $\mathrm{P} 20$ & Patrullero & M & 24 & 3 anos & 3 anos & Ensino médio \\
\hline P21 & Patrullero & M & 25 & 3 anos & 3 anos & Ensino médio \\
\hline
\end{tabular}




\begin{tabular}{|c|c|c|c|c|c|c|}
\hline P22 & Patrullero & M & 26 & 1 ano & 1 ano & Ensino médio \\
\hline P23 & Patrullero & M & 23 & 2 anos & 1 ano e 6 meses & Ensino médio \\
\hline P24 & Patrullero & M & 24 & $\begin{array}{l}1 \text { ano e } 3 \\
\text { meses }\end{array}$ & 1 ano e 3 meses & Ensino médio \\
\hline $\mathrm{P} 25$ & Patrullero & M & 23 & $\begin{array}{l}1 \text { ano e } 3 \\
\text { meses }\end{array}$ & 10 meses & Ensino médio \\
\hline P26 & Patrullero & M & 25 & $\begin{array}{l}4 \text { anos e } 5 \\
\text { meses }\end{array}$ & 3 anos & Ensino medio \\
\hline P27 & Patrullero & M & 25 & 3 anos & 3 anos & Ensino medio \\
\hline P28 & Patrullero & M & 24 & $\begin{array}{l}1 \text { ano e } 3 \\
\text { meses }\end{array}$ & 1 ano & Ensino médio \\
\hline P29 & Patrullero & M & 23 & 2 anos & 2 anos & Ensino médio \\
\hline P30 & Patrullero & M & 35 & 10 anos & 2 anos & Ensino médio \\
\hline P31 & Patrullera & $\mathrm{F}$ & 27 & 2 anos & 2 anos & Ensino médio \\
\hline P32 & Patrullero & M & 22 & $\begin{array}{l}1 \text { ano e } 6 \\
\text { meses }\end{array}$ & 1 ano e 6 meses & Ensino médio \\
\hline P33 & Patrullera & $\mathrm{F}$ & 25 & $\begin{array}{l}2 \text { anos e } 6 \\
\text { meses }\end{array}$ & 1 ano & Ensino médio \\
\hline P34 & Patrullero & M & 31 & 9 anos & 1 ano & Ensino médio \\
\hline P35 & Patrullero & M & 24 & $\begin{array}{l}1 \text { ano e } 3 \\
\text { meses }\end{array}$ & 1 ano & Ensino médio \\
\hline P36 & Patrullero & M & 34 & 6 anos & 2 anos & Ensino médio \\
\hline P37 & Patrullero & M & 31 & $\begin{array}{l}9 \text { anos e } 2 \\
\text { meses }\end{array}$ & $\begin{array}{l}9 \text { anos e } 2 \\
\text { meses }\end{array}$ & Ensino médio \\
\hline P38 & Patrullero & $\mathrm{F}$ & 26 & 6 anos & 1 ano e 6 meses & Ensino médio \\
\hline P39 & Intendente 1 & M & 39 & 20 anos & 2 anos & Ensino médio \\
\hline
\end{tabular}




\begin{tabular}{|l|l|l|l|l|l|l|}
\hline P40 & Intendente 2 & M & 43 & 23 anos & $\begin{array}{l}1 \text { anos e 6 } \\
\text { meses }\end{array}$ & Ensino médio \\
\hline PP41 & Intendente 3 & M & 331 & 14 anos & $\begin{array}{l}1 \text { anos e oito } \\
\text { meses }\end{array}$ & Superior completo \\
\hline
\end{tabular}

Fonte: PONAL

Além dos policiais, entrevistei a coordenadora do Programa CI2, dois moradores líderes e um professor da Universidade de Antioquia. Fiz outras entrevistas sem gravação com moradores, além de observar o trabalho policial nas ruas por onde circulava.

O ineditismo da pesquisa na polícia colombiana foi positivo porque provocou interesse por parte do comando nos resultados, principalmente pela Escuela de Posgrados. Com os patrulleros, o interesse foi também pela realidade brasileira, especificamente a carioca. Iam interessando-se ainda pelas perguntas na medida em que a entrevista avançava. No início, os entrevistados chegavam desconfiados, o que não deixa de ser um habitus ${ }^{40}$ desses profissionais, mas com o avanço da entrevista a desconfiança se diluía e eles se sentiam mais à vontade para falar.

\subsection{BRASIL}

\subsubsection{ENTRADA NO CAMPO DE PESQUISA - RIO DE JANEIRO}

\footnotetext{
${ }^{40}$ Habitus está sendo empregado segundo a concepção de Pierre Bourdieu com o significado da absorção da estrutura social pelo agente.
} 
Primeiramente, vale a pena ressaltar que, nos últimos cinco anos que antecederam o trabalho de campo, estive fora da cidade, pois residia em Brasília. Por essa razão, a entrada no campo demandou uma investigação prévia sobre o contexto local em termos de ação de polícia e violência, como também sobre o estado da arte da Polícia Militar do Estado, ou seja, a PM, como é chamada.

Minha trajetória profissional e acadêmica até o ano de 2010 foi desenvolvida no Rio de Janeiro, onde trabalhei em diversos projetos com as polícias estaduais, em pesquisas sobre as polícias e outros temas correlatos associados. Estabeleci durante mais de uma década, relações interpessoais com policiais, pesquisadores e núcleos de pesquisa voltados a esse tema. Evidentemente, o tempo é um fator vital em termos de relacionamentos e vínculos, afinal "quem não é visto, é esquecido".

Assim, por ter ficado fora da cidade e "longe das vistas" daqueles que foram os meus interlocutores na PM, precisei de um tempo para (re)encontrá-los e identificá-los na estrutura organizacional e hierárquica da polícia. A partir do que experimentei e conheço, via de regra a entrada no campo tem de ser facilitada por um membro ou figura simpática à comunidade a ser pesquisada. Na polícia, essa regra assume um peso ainda maior. Por ser a PM uma organização de rígida hierarquia militar ${ }^{41}$ verticalizada, para os policiais saber "com que estou falando", bem como a "patente" do civil, resulta em informações balizadoras da relação a ser travada. A "patente" do civil é definida, principalmente, com base em quem o está introduzindo no campo, ou seja, no grau hierárquico do interlocutor. No caso desta pesquisa, a entrada no campo ocorreu

\footnotetext{
${ }^{41}$ Muniz (1999) se debruçou sobre o tema polícia em sua tese de doutorado intitulada "Ser policial é, sobretudo, uma razão de ser", sendo esta uma das primeiras pesquisas acadêmicas de natureza qualitativa sobre o tema, realizada na PMERJ. Em sua pesquisa, a autora investiga a prática policial circunscrita à democracia, distinguindo as atribuições de polícia e do Exército, e ainda apontando a presença da "tradição militar, ancorada nos princípios da hierarquia e disciplina" (pg. 96) e suas implicações na organização policial militar e na atuação de polícia.
} 
por meio de um oficial, na ocasião do alto escalão da PM. Assim, todo o trabalho de campo foi formal e oficialmente autorizado.

A autorização formal é tanto um quesito quanto uma necessidade para a realização de uma pesquisa na polícia. Trata-se do passe de entrada nas unidades de polícia a serem pesquisadas. Sem ela, os comandos de unidades policiais (batalhões, escolas, unidades administrativas etc) não permitem que o trabalho seja feito. A excessiva formalidade e burocratização dos processos administrativos têm como pano de fundo o medo da punição, que, por sua vez, é reflexo da escassa autonomia para algumas questões que os comandos e policiais possuem - e que atingem todos os graus da hierarquia policial, em medidas e dimensões distintas. O processo de responsabilização e autonomia policial continua sendo um assunto de pouco avanço em termos práticos na PM. A exemplo da brincadeira de criança chamada "batata quente”, ninguém quer segurá-la simplesmente porque, para ganhar o jogo, o participante não pode estar com essa batata quente nas mãos. Analogamente, os policiais evitam, ao máximo, responsabilizar-se por algo ou, metaforicamente, "segurar a batata quente". Acabam por fazer tudo que é possível para estarem amparados por uma autorização oficial de origem no alto escalão, preferencialmente. Esse é o escudo de proteção institucional contra punições (e responsabilização) por qualquer ação tomada.

Sem dúvida, a questão da autonomia policial é um ponto cego na polícia. A autonomia dos policiais está atrelada a seu grau hierárquico. Há dois grandes grupos que subdividem os policiais em oficiais e praças: aos praças cabe a execução da atividade-fim de polícia, que na PM é o policiamento ostensivo; aos oficiais, realizar a gestão da instituição, definir e determinar a execução das atividades de polícia. Os oficiais dispõem de poder de mando e de punição sobre os praças, além de mais autonomia. Há aproximadamente uma década, não era raro ouvir de oficiais que "os praças não tinham que pensar, mas apenas obedecer ordens". Formalmente pode ser assim, entretanto, no trabalho de polícia, não há policial que não goze de autonomia, 
ainda que velada ou dissimuladamente. Na esfera administrativo-burocrática, os oficiais detêm a autoridade formal para tomar decisões e deliberar sobre assuntos diversos. Nas ruas onde as atividades-fim de polícia são executadas (MUNIZ, 1999; ANJOS, 2010), não há como realizar o trabalho de polícia sem dispor de autonomia para a tomada de decisão. Durante a pesquisa, ouvi oficiais comentando que "isso já está mudando", embora mudanças levem tempo, principalmente quando ocorrem em instituições altamente burocratizadas e centenárias. Assim o processo de tomada de decisão do policial configura o tema sobre o qual a pesquisa de campo se concentrou, tonando-se a razão de ser deste estudo.

\subsubsection{SOBRE A DEFINIÇÃO DAS UNIDADES DE POLÍCIA, TEMPO E FOCO DA}

\section{PESQUISA}

Fiz contato com um oficial de alto escalão - como já mencionado - para apresentar a minha pesquisa e conseguir a autorização, no melhor dos cenários, já de imediato. O oficial me recebeu com deferência e respeito, parte por ser popularmente tido como uma pessoa carismática e "gente boa", parte por sermos conhecidos, pois participamos de algumas iniciativas desenvolvidas na PM. Sua posição hierárquica lhe permitiu conceder a permissão. Em outros momentos, quando a instituição foi comandada por policiais mais avessos à pesquisa e, sobretudo, a um tema que poderia contribuir para a formação ou consolidação de uma imagem negativa, a autorização teria sido negada. Negar no modus operandi policial pode significar não responder ao pedido, sem justificativa. Esse fato exemplifica que até a negação não é assumida, mas, pelo contrário, velada, como uma forma de não responder pelo ato de negar. Esse fenômeno pode ser ilustrado no ditado popular: "o uso do cachimbo deixa a boca torta". 
Durante a reunião de apresentação do meu projeto de tese, depois de explicar "rapidamente" (já que os oficiais têm sempre uma burocracia extensa e diária para cumprir, com urgências sobrepondo outras urgências) que o fator tempo sofre racionamento, recebi o esperado "aceite". Assim, o passo seguinte foi materializar a aprovação em um ofício, de fato o passe de entrada "no preto e no branco". A definição das unidades a serem abordadas também ocorreu nesse momento porque aproveitei para identificar qual seria a UPP com a experiência mais consolidada, segundo a PM. Foi apontada a UPP Santa Marta, a unidade mais antiga, sendo essa favela a primeira em que foi implantado tal policiamento.

Com a autorização garantida e a definição da unidade policial, a próxima etapa foi conseguir os contatos dos comandantes para que pudesse apresentar a mim e ao projeto de pesquisa novamente. Para tal, fiz contato com o EMG, que me cedeu os telefones dos comandantes. Em seguida, primeiramente, procurei o comando das UPP, repetindo esse ritual de apresentação, para, posteriormente, enviar a autorização por e-mail. Nessas conversas, depois afirmar que a pesquisa foi autorizada, chega o pedido "me envie a autorização". Depois de comprovar tudo o que foi perguntado, fase consecutiva é a de fazer contato com os comandos das unidades a serem abordadas. E, mais uma vez, passar pelos questionamentos das instâncias superiores. O percurso para a autorização demorou algumas semanas, que, para os prazos do doutorado, acabou por gerar atraso no cronograma previsto. E tais atrasos vão gerando outras delongas, assim gerando uma bola de neve em declive - difícil de parar.

Diante do fim da jornada de autorização, comecei, por fim, as entrevistas na UPP Santa Marta, depois de entrar em acordo com o comando da unidade sobre qual seria a estratégia de seleção dos policiais. Como o meu interesse de pesquisa está centrado no trabalho de polícia, escolhi entrevistar os praças. Definido isso, foi preciso identificar a forma de abordá-los e o local junto ao comando. Como trabalham por escala, a hipótese de entrevistá-los depois do plantão fez-se inviável. Em geral, depois do trabalho, os policiais seguem diretamente para a 
sua segunda jornada de trabalho - o famoso "bico" - ou simplesmente vão cuidar de sua vida pessoal e, principalmente, descansar. Por isso, não se pode contar com eles depois do trabalho. Para entrevistá-los, tive de abordá-los durante o expediente na PM. Para tal, foi necessária uma convocação formal do comando, ou seja, não foi uma participação voluntária, pelo menos inicialmente.

Ainda faltava identificar o local das entrevistas. Esse é um assunto complexo, já que não podiam sair da área de trabalho, que é o próprio morro, exceto com autorização prévia. Para isso, seria necessário disponibilizar uma viatura para o transporte. Isso significaria garantir organização e logística, além de contar com a sorte de não ter as viaturas ocupadas por qualquer outra razão prioritária. Outro cenário seria conseguir uma instituição local que pudesse ceder um espaço para as entrevistas. Essa opção demanda a garantia de um espaço onde não se pudesse escutar a entrevista e que aceitasse receber os policiais. Apesar da UPP estar há um tempo considerável na favela, já que foi inaugurada em 2008, a relação entre moradores e policiais permanece em construção. Há ressentimentos, desconfiança e medo dos policiais e, portanto, franquear esse espaço não se mostrou, no fim, como uma alternativa.

Restou a UPP, que, no Santa Marta, ocupa um edifício no qual funcionava uma instituição de ensino. No entanto, o prédio estava passando por reformas, o que reduziu em muito os espaços utilizáveis para essa finalidade. Decidi fazer as entrevistas nas instalações da UPP, tendo de adaptar o espaço para assegurar a devida privacidade, mudando de um lado a outro, movimento que eles também faziam para atender às demandas da reforma. Fiz entrevistas em vestiários, salas de trabalho e qualquer outro espaço disponível que oferecesse privacidade. Os policiais, durante seu turno de trabalho, deixavam seu local de plantão pelo tempo da entrevista, regressando logo em seguida. Fiz as entrevistas durante algumas semanas, assim procedendo com quem estava de plantão no momento. Essa foi a estratégia mais aleatória possível em termos de seleção de entrevistados. Mesmo com a "determinação" do comando 
para a participação dos entrevistados e dos limites do espaço para a iniciativa, os resultados foram satisfatórios.

Inicialmente, estabeleci uma meta de 20 (vinte) entrevistas, mas, durante a primeira semana de pesquisa, percebi que não seria possível chegar a esse total estimado. A estratégia, por fim, desenhada como o comando, foi a de, a cada dia, convocar alguns policiais de plantão, sem prejudicar as atividades desenvolvidas. Isso se traduz em "vamos ver quantos policias será possível tirar do plantão". Como estratégia de inserção no campo, a entrevista em um lugar fora do morro foi a mais factível pelo fato de o policiamento no morro ser realizado por meio de rondas pelo território. Para isso, os policiais estão necessariamente acompanhados por um ou mais colegas, fato este que não lhes garante privacidade para a entrevista. As escadarias do morro são a única via de circulação dentro da comunidade, que passam muito próximo das residências, o que permite que as conversas, tanto dentro quanto fora das casas, sejam escutadas. Essas características também prejudicariam a privacidade necessária: o trabalho da polícia na comunidade se realizava pelo deslocamento permanente pelo território, com pequenos espaços para descansar. Por essas questões, o local de trabalho dos policiais não se configurou como uma alternativa produtiva. A escolha por fazer a entrevista em um local fixo foi a que mais se adequou às especificidades do perfil de atividades policiais no local.

Ao alcançarmos a terceira semana, notei cansaço por parte dos que convocavam, pois a retirada de policiais dos seus locais de trabalho parecia estar incomodando. O campo estava me dizendo "até aqui está bom", ou seja, não havia mais condições para seguir com a rotina necessária. Por isso, foram realizadas dez entrevistas ao todo. Desse montante, oito foram com homens e duas com mulheres. Entre os policiais entrevistados, foram nove soldados, além de um cabo. Entrevistei, ainda, a então comandante da UPP. 


\subsubsection{PeRfil dos ENTREVISTAdos}

\section{Quadro 7: UPP Santa Marta}

\begin{tabular}{|c|c|c|c|c|c|c|}
\hline & $\begin{array}{l}\text { Grau } \\
\text { hierárquico }\end{array}$ & Sexo & Idade & $\begin{array}{l}\text { Tempo } \\
\text { de } \\
\text { trabalho } \\
\text { na PM }\end{array}$ & $\begin{array}{l}\text { Tempo de } \\
\text { trabalho } \\
\text { na UPP }\end{array}$ & $\begin{array}{l}\text { Grau de } \\
\text { formação }\end{array}$ \\
\hline Policial 1 & Soldado & $\mathrm{F}$ & 35 & 2 anos & 1 ano & Ensino médio \\
\hline Policial 2 & Soldado & M & 24 & 4 anos & 3 anos & $\begin{array}{l}\text { Superior } \\
\text { incompleto }\end{array}$ \\
\hline Policial 3 & Soldado & M & 28 & 4 anos & 1 mês & Ensino médio \\
\hline Policial 4 & Soldado & M & 35 & $\begin{array}{l}2 \text { anos e } 7 \\
\text { meses }\end{array}$ & 5 meses & Ensino médio \\
\hline Policial 5 & Soldado & M & 30 & 3 anos & $\begin{array}{l}1 \text { ano e } 6 \\
\text { meses }\end{array}$ & $\begin{array}{l}\text { Superior } \\
\text { incompleto }\end{array}$ \\
\hline Policial 6 & Soldado & $\mathrm{F}$ & 34 & 2 anos & 6 meses & Ensino médio \\
\hline Policial 7 & Soldado & M & 28 & 2 anos & 4 meses & Ensino médio \\
\hline Policial 8 & Soldado & M & 26 & 2 anos & 1 ano & $\begin{array}{l}\text { Superior } \\
\text { incompleto }\end{array}$ \\
\hline Policial 9 & Cabo & M & 33 & 8 anos & 7 anos & Ensino médio \\
\hline Policial 10 & Soldado & M & 28 & 2 anos & 1 ano & Ensino médio \\
\hline Policial 11 & $1^{\mathrm{o}}$ Tenente & $\mathrm{F}$ & 31 & 7 anos & 2 meses & Pós-graduação \\
\hline
\end{tabular}

Fonte: PMERJ 


\section{Quadro 8: 20 BPM}

\begin{tabular}{|c|c|c|c|c|c|c|}
\hline & $\begin{array}{l}\text { Grau } \\
\text { hierárquico }\end{array}$ & Sexo & $\begin{array}{l}\text { Ida } \\
\text { de }\end{array}$ & $\begin{array}{l}\text { Tempo de } \\
\text { trabalho } \\
\text { na PM }\end{array}$ & $\begin{array}{l}\text { Tempo de } \\
\text { trabalho na } \\
\text { UPP }\end{array}$ & $\begin{array}{l}\text { Grau de } \\
\text { formação }\end{array}$ \\
\hline Policial 1 & Sargento & M & 44 & 20 anos & 19 anos & $\begin{array}{l}\text { Ensino } \\
\text { médio }\end{array}$ \\
\hline Policial 2 & Soldado & M & 27 & 2 anos & $\begin{array}{l}1 \text { ano e } 6 \\
\text { meses }\end{array}$ & $\begin{array}{l}\text { Ensino } \\
\text { médio }\end{array}$ \\
\hline Policial 3 & Soldado & $\mathrm{F}$ & 30 & 3 anos & 3 anos & $\begin{array}{l}\text { Superior } \\
\text { incompleto }\end{array}$ \\
\hline Policial 4 & Soldado & M & 30 & 2 anos & $\begin{array}{l}1 \text { ano e } 6 \\
\text { meses }\end{array}$ & $\begin{array}{l}\text { Superior } \\
\text { incompleto }\end{array}$ \\
\hline Policial 5 & Soldado & M & 35 & 2 anos & 1 ano & $\begin{array}{l}\text { Ensino } \\
\text { médio }\end{array}$ \\
\hline Policial 7 & Coronel & M & 48 & 25 anos & 4 meses & $\begin{array}{l}\text { Pós- } \\
\text { graduação }\end{array}$ \\
\hline
\end{tabular}

Fonte: PMERJ

Esse desenho metodológico resultou em quinze entrevistas com praças e duas com oficiais. O conteúdo coletado e a observação de campo foram suficientes para o que se pretendia. No Brasil, já disponho de outros trabalhos realizados junto a PM, inclusive a minha dissertação de mestrado - fato que me permite partir de um ponto inicial nesta pesquisa já com uma base de conhecimento anterior. Além disso, a produção bibliográfica sobre o tema também aporta um valioso background. 


\section{Outras entrevistas}

Com o propósito de ampliar a minha base de investigação, entrevistei o comandante do CEFAP, onde ocorrem a formação os e demais cursos de aperfeiçoamento profissional para praças, e o $\mathrm{PM}^{42}$ da PMERJ. Isso contribuiu para que eu pudesse compreender o processo de formação dos praças, o qual imputa nos policias valores culturais e o modus operandi da PM.

Notou-se, em algumas entrevistas, disponibilidade e interesse de imediato dos entrevistados; com outros, o interesse foi surgindo durante a conversa. Não houve quem não tenha se envolvido com a entrevista a partir de um determinado momento. Não percebi resistência ou temor de responder as perguntas, pelo contrário, via de regra, sentiram-se à vontade no espaço de entrevista. Essa característica talvez se explique pelo fato de as UPP serem alvo de diversas pesquisas. De fato, ao me apresentar na UPP, alguns policiais perguntaram se eu pertencia a alguns núcleos de pesquisas que conhecem por já terem passado pelo processo de entrevistas. Eles comentaram: “Já fizeram muitas entrevistas nas UPP. Todo mundo quer saber sobre as UPP”. Isso me impeliu a crer que estão acostumados com entrevistas, o que pode explicar o não estranhamento ao meu trabalho de pesquisa.

Depois de finalizadas as entrevistas, foi possível perceber que as falas estavam alinhadas em termos de visão sobre a autonomia policial, ou seja, as respostas eram semelhantes a ponto de se pensar que havia algo errado. O "problema" poderia estar no roteiro, ou no perfil dos entrevistados, já que majoritariamente entrevistei soldados que tinham passado a maior parte de seu tempo de trabalho em UPP, desenvolvendo uma ação de polícia circunscrita à realidade das favelas. Diante do cenário descrito, pareceu necessário testar o roteiro. Para tal, tomei como referência o $2^{\circ}$ BPM, um batalhão tradicional de polícia localizado no bairro de Botafogo. Tendo definida essa unidade, fiz contato com o seu comando. A UPP Santa Marta está ligada

\footnotetext{
${ }^{42}$ A gestão da PM se divide em seções, em total de cinco. A $3^{\text {a }}$ Seção, chamada PM3, é responsável pelo planejamento operacional da polícia.
} 
administrativamente ao $2^{\circ} \mathrm{BPM}$, o qual mantém os equipamentos, armamento e viaturas. $\mathrm{O} 2^{\circ}$ BPM cobre os seguintes bairros: Botafogo, Cosme Velho, Glória, Flamengo e Aterro do Flamengo. Esses bairros emprestam ao batalhão diversidade de ocorrências, o que parece ser oportuno para testar o roteiro.

Após acertar os detalhes e necessidades para a realização das entrevistas - espaço reservado e com privacidade -, defini com o comando um calendário de entrevistas. Nessa unidade, consegui entrevistar seis policiais, além do comandante. Foi decisivo testar o roteiro, pois pude afastar o fantasma que me assombrava, até porque foi validado pelo fato de os resultados apontarem visões distintas sobre assuntos centrais da pesquisa. Isso afastou a possibilidade de o roteiro não estar alcançando o objetivo, já que, ao mudar o perfil dos entrevistados, pontos de vista diferentes foram surgindo. Essa constatação acabou por gerar mais confiança no roteiro, que foi o mesmo adotado na Colômbia, com as necessárias adaptações. 


\section{REFERENCIAL TEÓRICO}

Os estudos internacionais sobre polícia têm sido produzidos por alguns autores, que acabaram se tornando referências nesse campo de estudo. Entre esses, destaca-se Bittner (2003), o qual discute questões associadas ao policiamento urbano observado na relação com públicos distintos, em áreas geográficas com características específicas, como também sobre controle e legalidade da ação policial. Bittner, nessa obra, avançou na elaboração de uma teoria de polícia que, até a atualidade, continua sendo uma importante produção acadêmica para o tema. O autor inicia o seu trabalho sinalizando a presença ambivalente da polícia na sociedade moderna.

Considerando-se a polícia a instituição mais popular por sua presença nas diversas esferas da vida social - e ainda mais a corporação que está no espaço público, cotidianamente realizando o policiamento nas ruas e assim provocando encontros involuntários com a população -, pode-se afirmar que a sua visibilidade é incomparável diante de outras instituições

públicas. É possível inferir que todos já tiveram (ou terão) contato com a polícia de maneira direta ou indireta, em algum momento de sua vida. A polícia é, reconhecidamente, o recurso mais disponível que um Estado dispõe.

Já em termos de estudos e pesquisas, relativamente há pouco tempo, a polícia vem se constituindo como objeto de interesse quando comparada à saúde, educação e justiça. Nesse sentido, a ambivalência se encontra na visibilidade e presença juntamente com o desconhecimento ou baixo interesse acadêmico que a atingem. Na sociedade moderna, é pouco provável que ela seja indiferente ou desconhecida pelas pessoas e, mesmo assim, não figurou no rol de interesses científicos até pouco tempo.

Bayley, outro referencial relevante no campo de estudos sobre polícia, corrobora com a perspectiva da invisibilidade acadêmica do tema, acrescentando que 
O policiamento pode ter sido negligenciado porque é repugnante moralmente. Coerção, controle e opressão são sem dúvida necessários na sociedade, mas não são agradáveis. Embora a guerra também não seja algo agradável, ela pode parecer heroica (BALEY, 2006, p. 18).

O heroísmo, que pode ser atribuído a um soldado que defende uma nação e seu povo, não conta no conjunto de adjetivações popularmente direcionadas ao trabalho policial. Realmente, à polícia cabe controlar, inibir, impedir ações, atitudes e comportamentos tratados como indesejáveis ou inadequados dentro de um contexto temporal, histórico e político. Em geral, sua ação gera aversão, revolta e descontentamento e, por consequência, esses aspectos diferenciam e afastam o ofício policial do trabalho militar em situações de guerra, como também das atividades de bombeiros, que têm como prerrogativa o salvamento de vidas.

Nesse sentido, a prática policial não é concebida como uma atividade nobre como é o salvamento, nem heroica como é a do soldado guerreiro. A existência, presença e atividade policial refletem, grosso modo, a incapacidade da própria sociedade em lidar e resolver seus dilemas, conflitos e diferenças. Assim, compreender e explicar a função, a natureza e os objetivos do trabalho de polícia se converte em uma tarefa árdua e complexa. Para Bittner, nem a própria polícia tem evidenciado ser capaz de definir ou conceituar a natureza de sua ação. Nas palavras do autor:

O que é verdade acerca das pessoas é também verdade no que toca à polícia. Os policiais não foram bem sucedidos em formular uma justificativa para sua existência que, de modo reconhecível, pudesse ser relacionada ao que eles de fato fazem (sem contar aquelas atividades de seu labor que eles desaprovam ou condenam). A situação é semelhante à de uma pessoa que, quando solicitada a explicar como fala, dá uma descrição que, embora esteja em perfeita ordem linguística, não chega nem perto de fazer justiça à habilidade envolvida na produção de um enunciado. (BITTNER, 2003, p.219).

A partir da atualidade como referência, nota-se que a polícia - como instituição estatal dirigida pelo governo a serviço da sociedade ou do bem-comum - encontra-se no cerne de um 
dilema. Sendo concebida como força pública de controle e regulação da sociedade, a ação de polícia é historicamente circunscrita, de maneira simplista, na aplicação da lei, ou seja, como uma agência pública destinada a aplicar a lei e fazer com que esta seja cumprida - por isso, a utilização da expressão law enforcement. Esse termo representa uma das concepções ou correntes de pensamento que entende o trabalho de polícia como delimitado e dedicado à imposição da lei.

Em termos práticos, os policiais estariam, segundo essa visão, garantindo a execução da lei, e adotando a legislação como referência e meta para a execução do seu trabalho. Avançando nesta linha de pensamento, os policiais são entendidos como "law enforcers by force" (ANJOS, 2010, p.23), cuja redundância não casual serve para destacar que estes exercem suas atividades utilizando a força real ou potencial para alcançar o cumprimento da lei.

Em contraposição, encontra-se a linha de pensamento que concebe a polícia como uma agência de manutenção da ordem. Cabe aqui sinalizar que as atividades de manutenção da ordem estão diretamente vinculadas ao cotidiano da vida em sociedade, à convivência, em geral. E, nesse caso, a ordem diz respeito aos acordos comunitários entre indivíduos estabelecidos para esse fim, não necessariamente prescritos na lei. A ordem para um grupo pode significar arranjos particulares elaborados para atender às suas expectativas, em um dado momento. A manutenção da ordem, assume, assim, um caráter mais amplo e discricionário, que exige contemplar especificidades possivelmente não definidas na lei.

O dilema presente na manutenção da ordem e aplicação da lei vem sendo abordado em diversos estudos (COSTA, 2004; BITTNER, 2003; SKOLNICK, 1994) por representar a angústia social e institucional acerca da função da polícia no cenário democrático. Bittner propõe a integração dessas dimensões à prática policial como alternativa ao dilema, ao apontar que a polícia já realiza tanto uma como outra, sem prejuízo de nenhuma. Essa é, notadamente, 
a perspectiva mais integradora do trabalho policial, a qual o compreende como realmente é: complexo, diverso e multifacetado.

Monet traz uma contribuição significativa para o debate, por inscrevê-lo nos princípios democráticos. Para o autor, em uma democracia, a lei se presta a assegurar que as minorias não sejam oprimidas pela maioria e, portanto, o exercício de seus direitos seja defendido. Segundo ele, a perspectiva da ordem diz respeito à centralidade dos valores de uma sociedade apoiados no acordo feito pela maioria e que, por isso, o pacto com a maioria empresta legitimidade ao acordo. No entanto, a lei precede à ordem para explicitar que, em situações contraditórias, a proteção aos diretos das minorias prevalece em relação aos valores da maioria.

Em suma: 'a lei e a ordem' [grifo do autor] significa que, em todas as circunstâncias, a preocupação de manter o pacto social que une maioria e minoria deve permanecer prioritário, mesmo em detrimento das convicções ou das paixões da maioria. (MONET, 2006, p. 239).

A perspectiva do autor insere a questão da lei e da ordem em um contexto político ampliado e, com isso, dá mais robustez à discussão, a qual, relacionada diretamente com o jogo democrático, faz-se ainda mais relevante, pertinente e atual. Quanto à polícia, o autor aponta que a hierarquização das prioridades se inverte. , já que deve priorizar a ordem pública. Em suas palavras,

Em relação à ação policial, todavia, os termos se invertem e a ordem passa sempre à frente da lei. Ao mesmo tempo que se opera essa translação, é a aceitação da autoridade estatal que ela encarna. A lei é o dispositivo fundador que legitima essa autoridade. Mas, no domínio da manutenção da ordem, a lei é equívoca. Precisa para determinar as infrações que protestários podem comentar, ela é mais flexível quanto aos meios que a polícia deve utilizar e quantos às finalidades exatas que suas intervenções devem perseguir. Esse caráter equivoco da lei resulta, provavelmente, do duplo desafio que todo movimento coletivo lança à democracia: desafio ligado à necessidade de conciliar direitos antagônicos - direito de manifestação e direito de circular, por exemplo - e desafio ligado ao fato que todo protesto coletivo na rua tende a demonstrar que as instituições políticas são falhas. Mesmo as violências coletivas sem projeto político explicito, como as dos hooligans, se enraízam num terreno cujo tratamento depende do político e não do policial. De outro lado, a ambiguidade da lei constrói o espaço que dá à polícia uma de autonomia decisória considerável. (MONET, 2006, p. 239) 
O trabalho de polícia não cabe em definições restritivas e limitantes, que o colocam em um papel estático e impermeável, ou que a posicione no centro do exercício do controle social. Evidentemente, a polícia realiza controle social, mas não de maneira solitária e exclusiva (COSTA, 2004), à medida que o controle social é alcançado em muitas instâncias e instituições sociais, a começar pela própria família. Sobre a polícia, não deve repousar a expectativa do controle social de maneira exclusiva, porque são diversos os mecanismos criados em uma sociedade que se incumbe igualmente dessa tarefa.

Desse modo, o cumprimento da lei e a preservação da ordem pública são elementos da prática policial que podem ser considerados como framework da ação de polícia, já que, diuturnamente, esta faz a mediação de conflitos, socorre e salva vidas, além de resgatar pessoas e animais em situação de risco. Esses são alguns exemplos do conjunto de ações levadas a cabo por um profissional de polícia, pois enunciar o que a polícia faz equivale a enumerar as possíveis situações que podem ser geradas na interação humana. Talvez uma tarefa impossível e desnecessária. Impossível, pois a capacidade humana de criar, inventar e reinventar é infinita; desnecessária, por desviar a atenção da verdadeira tarefa que deveria ser a definição da função da polícia. Definida a função, pode-se, então, estabelecer o mandato policial.

A definição da função e do mandato é reflexo da razão de ser da instituição policial. Nas sociedades modernas, as polícias buscaram a profissionalização com o objetivo de alcançar as definições em questão especialmente situadas no contexto democrático. A ideia da profissionalização dialoga, por sua vez, com a ansiedade de realizar um trabalho próprio, exclusivo e de forma organizada, estruturada em uma organização policial com linha de comando e hierarquia definidas, regulação da prática e construção de metas institucionais. Para Bittner, os policiais que propuseram o modelo profissional de polícia, surgido em 1950 nos Estados Unidos, sofriam influência do modelo militar da ocasião. Em suas palavras: 
Realmente, é muito mais provável que, ao falarem em policial profissional, esses homens tivessem em mente alguém semelhante ao soldado profissional, isto é, alguém seriamente empenhado em uma certa atividade, ao invés de um amador ou meramente um servil qualquer. Ser profissional, nesse sentido do termo, também significava honestidade pessoal e neutralidade política, e também significava o domínio de certas informações e habilidades. (BITTNER, 2003, p. 341).

A profissionalização de qualquer atividade profissional é um processo que se consolida ao longo do tempo, um exercício de acertos e equívocos, visto que essa equação é composta por muitas variáveis, que podem variar em momentos distintos. Há algumas etapas, no entanto, que são chave para esse processo, como a formação, a aculturação ou socialização dos profissionais recém-ingressados e a inserção no universo empírico laboral. Sendo a polícia uma instituição destinada a exercer suas atividades no campo empírico, este se torna, assim, o loco privilegiado da aprendizagem. Cabe ressaltar que

Muito embora se possam encontrar múltiplas interpretações acerca dos critérios específicos que podem precisamente definir uma "profissão", a quase totalidade dos estudos sociológicos sobre o tema tem enfatizado que o conhecimento formal, abstrato, de nível superior é um elemento indispensável para demarcar uma ocupação como "profissão". (PONCIONI, 2003, p. 38).

Indubitavelmente, o processo de formação consolidado em espaços formais de aprendizagem torna-se indispensável para qualquer profissão, e igualmente para os policiais. No entanto, a cultura da rua tem um peso extraordinário no trabalho policial, ainda mais contundente nas atividades de polícia ostensiva. A despeito de não ser possível restringir o processo de aprendizagem somente às ruas, tampouco à sala de aula, é evidente que nas ruas os profissionais acumulam experiências que se convertem em um tipo de saber profissional. De fato,

O contato com uma espécie de 'conhecer', saído da urgência dos fatos, que se confunde mesmo com o fazer e o agir, nos faz pensar que os policias que patrulham as ruas das nossas cidades sabem de coisas que não sabemos ou que não queremos perceber. Seu conhecimento é constituído aqui na esquina, dia após dia convivendo, de uma explicita e sem mediação, com a dimensão volátil, cômica, dissimulada, humilhante, violenta, confusa, vulnerável, trágica e frequentemente patética daquilo que chamamos de humano. (MUNIZ, 1999, p. 156 - 157). 
Os policiais nas ruas são a representação encarnada das prioridades, dos valores e do peso da mão armada do Estado. As atividades consideradas especializadas, como investigação e perícia criminais, desativação de explosivos, entre outras -indicando que o policiamento ostensivo não está posicionado no mesmo nível das demais atividades de polícia - se diferenciam porque objetivamente já são especificidades desenvolvidas para atender a propósitos e derivações sofisticadas da ação de polícia.

Nesse sentido, a prática policial nas ruas pode ser entendida como o cenário mais complexo e contundentemente atingido pela indefinição ou inexatidão do papel da polícia na (e para a) sociedade democrática. Curiosamente, o policiamento ostensivo é a atividade de polícia mais antiga (o que se conhecia como vigilância), a que mais consome o quantitativo policial, concentra a atenção pública e expõe a instituição, dado que "a atribuição designada para a maior parte dos policiais em todo o mundo é o patrulhamento" (BAYLEY, 2006, p.119).

O policial nas ruas é o cartão de visitas da polícia, é aquele que veste a camisa institucional e sai às ruas colocando a cara a tapa muito mais que a beijos. Para Bittner, esse perfil desenvolveu, ao longo da existência da polícia, uma cultura particular e distinta do policial que realiza outras funções. A pluralidade e a complexidade do policiamento conformam a base da construção da cultura e identidade do policial das ruas.

O fazer polícia nas ruas significa lidar com o que a humanidade é capaz de produzir em termos de idiossincrasias, dilemas, incoerências, contradições, ambições, gostos e desgostos. Muito frequentemente, a matéria bruta do trabalho dos policiais são eventos que revelam aspectos da vida humana que são desagradáveis aos sentidos, provocam reações de asco, medo, incredulidade diante de fatos (ou ocorrências policiais) e que parecem saltar das telas ou dos livros de ficção. A realidade cotidiana do policial nas ruas é criada e recriada demandando 
desses profissionais um fazer polícia construído na escola dinâmica das ruas. E isso se constitui no saber policial, um saber

\begin{abstract}
Atrelado ao episódico, constrangido pelas contingências, parece resistir a padronização. Ele está ali em cada evento, na memória prodigiosa de cada policial. Ele é parte indissociável da trajetória de vida e das experiências individuais vividas por um personagem que deve aprender a observar - de um lugar em movimento (a ronda), de um lugar vigilante - 'os outros' personagens que desenham o cenário urbano. Este tipo de saber descobre-se atento ao menor indicio de 'anormalidade'; ele está à procura do que se encontra fora do lugar, ele se põe em perseguição a tudo aquilo que pareça, à primeira vista, 'incorreto', 'indevido', 'inadequado' (...). (MUNIZ, 1999, p. $154-155$ ).
\end{abstract}

Todos esses elementos configuram o saber e a cultura policial das ruas, e se constituem característicos de uma atividade profissional única. $\mathrm{O}$ processo de formação e a prática nas ruas são as ferramentas que forjam a matéria-prima que representa o profissional recémingresso. Ambos os processos definitivamente são constitutivos da identidade policial. No entanto, as ruas são a escola por excelência da prática policial, a qual se desenvolve e se aperfeiçoa na interação social, nas experiências incontáveis que um plantão policial pode gerar. O exercício da atividade policial informado pelo processo de aprendizagem nas salas de aula produz um complexo e denso corpo de conhecimentos que se configura no saber policial, permitindo ao policial fazer leituras da realidade, interpretar e ressignificar o seu cotidiano.

A contribuição de Bayley ao debate, da mesma forma, propõe-se a elaborar uma teoria de polícia. Um dos pontos sobre os quais centra a sua discussão são as questões relacionadas à legitimidade e à autorização do trabalho de polícia. Para o autor, a autorização é um elemento definidor do trabalho profissional de polícia, pois a instituição policial não se cria sozinha; está necessariamente vinculada a uma unidade social, da qual deriva o seu poder. No entanto, a autorização não determina como esse poder se organiza para ser exercido.

Legitimidade e consentimento são temas contundentes para a ação policial, pois em uma sociedade complexa e moderna há uma diversidade de interesses em permanente disputa por hegemonia. O que é legítimo atualmente, não necessariamente o foi no passado, como também 
pode variar para distintos grupos em um mesmo momento histórico. No entanto, é preciso contar com uma base comum de valores sociais e éticos que permita definir os contornos de legitimidade para a ação de polícia; caso contrário, a prática policial seria inexequível porque demandaria ser reacordada ad eternum. Dessa forma, evidencia-se que a regulação de assuntos internos de uma sociedade não é uma tarefa simples, além do fato de esta se manter na pauta do dia até a atualidade.

Todos esses temas estão diretamente relacionados com o poder de polícia, ou mesmo podem ser compreendidos como elementos que o compõe. E se trata de um assunto importante na produção desse autor. Segundo os seus estudos, uma variável explicativa do grau do poder de polícia é o desenvolvimento econômico de um país, ou seja, nos mais pobres e menos desenvolvidos, a polícia goza de maior poder. Outra variável explicativa é a desigualdade interna de um mesmo grupo social. A relação entre poder de polícia e desigualdade, nesse caso, consolida-se de maneira diretamente proporcional: quanto maior a desigualdade interna, maior a força da polícia. Esses são esforços explicativos que, porém, não esgotam a totalidade de variáveis implicadas no poder de polícia, mas que tampouco perdem a sua validade para esse fim. Cabe comentar que

No cômputo geral, o poder da polícia parece responder mais às necessidades de segurança da elite do que do público em geral, mas as elites provavelmente associam as necessidades de segurança de todo tipo com o crescimento da população, assim servindo tanto ao público quanto a elas mesmas pela expansão concomitante do poder da polícia. (BAYLEY, 2006, p.114).

Portanto, o poder de polícia se converte em um fenômeno fundamental para se avançar sobre a própria razão de ser da força policial, , por isso,

Deve ser abordado em suas manifestações no dia a dia, ou seja, na relação entre a polícia e a sociedade, no controle que a polícia exerce sobre as relações interpessoais e grupais. Em última análise, ele se traduz na capacidade ou prerrogativa da instituição 
de interferir e controlar o modus vivendi em uma 'polity"43 [grifo do original] por meio do cerceamento de liberdades e direitos, motivados pelo bem-comum, pela manutenção da ordem, pela garantia de uma segurança pública" (ANJOS 2010, p. 21).

O poder de polícia observado na própria prática policial pode revelar a autoridade policial exercida e estimulada nas dinâmicas e interações. Entretanto, não apenas onde a polícia já se faça presente, como também em situações que representem a possibilidade de estar presente. A eventual presença do policial já antecipa a sua autoridade, posto que o prenúncio da sua chegada se converte em um fator dissuasivo da problemática em curso. O recurso "vou chamar a polícia" funciona como uma ameaça que antecipa o poder de polícia ainda não concretizado, portanto, sem a aplicação de meios de coerção real. Assim, o poder de polícia não se materializa exclusivamente pela aplicação da força, mas também pelo seu uso potencial.

Quatro prerrogativas se unem para dar forma ao poder de polícia: i) uso da força real ou potencial; ii) impossibilidade de resistência; iii) legitimidade; iiii) legalidade. O uso da força policial está circunscrito à legislação de uma comunidade política, fator que confere legalidade à ação de polícia. A comunidade política - que autoriza a polícia a exercer controle social sobre ela mesma - detém a prerrogativa do consentimento, a qual, em geral, se configura como a autorização para atuar, representando a permissão necessária à polícia. Sem consentimento não há legitimidade. Não obstante, vale reforçar que, em uma sociedade plural e complexa, consentimento e legitimidade são temas geradores de polêmicas e dissenso. A disputa entre interesses, não raro conflitantes, por parte de grupos sociais distintos, produz um contexto polarizado e diverso, no qual a definição de prioridades transforma-se em um constructo. A tentativa de estabelecer o que é legítimo para a ação de polícia é impactada por esse cenário, pelos vieses e reveses da sociedade em questão e, assim, confrontada temporal, política e territorialmente por verdades cambiantes.

\footnotetext{
${ }^{43}$ Polity, na citação, foi usada para indicar uma unidade ou comunidade política e seu governo.
} 
Isto significa dizer que o elemento legitimante da decisão discricionária, isto é, o termo inicial de avaliação da workmanship, em termos políticos, é a convergência moral entre a decisão discricionária da polícia e o que o público reconhece, de bom ou mau grado, como razoável. (PROENÇA JUNIOR, MUNIZ \& PONCIONI, 2009, p.36)

O desafio para a polícia é encontrar uma solução prática, aplicável que contemple o legal e o legítimo, ou seja, conseguir os "feijões mágicos" que levam à "galinha dos ovos de ouro", dizendo de maneira jocosa. Realmente, não há magia, fórmula ou receita para esse fim, justamente por ser um exercício permanente que resulta em erros, acertos, avanços, retrocessos, impasses e dilemas, assim refletindo o próprio jogo democrático. A prerrogativa da tomada de decisão legal e legítima está assentada no poder discricionário do policial, que, por sua vez, se sustenta nas experiências de vida e laborais, nos conhecimentos e saberes acumulados individualmente, como também produzidos de forma coletiva. Assim, a aplicação mecânica da lei e de preceitos de manutenção da ordem, desde uma perspectiva desprovida de subjetividade, inscreveria a ação policial em uma dimensão quase robótica, infactível, ficcional.

Skolnick (1994) enfatiza que há um dilema entre o quanto de discricionariedade a atividade policial pode usufruir em contraposição aos limites da lei e do controle. Para o autor,

\begin{abstract}
If the central task of administration of criminal law is to balance the conflicting principles of order and legality, the dilemma is epitomized in the question of police discretion. Whether ones sees legality undermined for the sake of order, or vice versa, the issue reduces to whether there ought to be a loosening or tightening on the decisional latitude of police. The issue has recently been given increasing attention by legal scholars concerned primarily with how much discretion police ought to have and how this discretion may be controlled. (SKOLNICK, 1994, p. 69).
\end{abstract}

Sem dúvida, é uma preocupação sustentada não somente por estudiosos, como também pela sociedade, governantes e a própria polícia. Goldstein (2003) desenvolveu um estudo que categoriza as principais formas que o poder discricionário policial é exercido, da seguinte maneira: (a) na escolha dos seus objetivos: tal opção atinge os níveis administrativo e operacional, abrangendo desde os critérios de avaliação do desempenho policial até a 
implantação de unidades especializadas, passando pela escolha dos crimes que serão priorizados seja nas patrulhas seja no atendimento das chamadas telefônicas; (b) na escolha dos métodos a serem adotados: refere-se à definição de qual gradação de força dever ser aplicada, variando da repreensão verbal à ação letal; (c) na escolha de formas alternativas dos dispositivos legais: essa decisão transita em torno da escolha por envolver ou não o sistema de justiça criminal, ou seja, se a infração cometida deve ser levada adiante por meio de processos judiciais ou apenas ser objeto de repreensão; (d) na escolha dos métodos de investigação: nesse campo há um grande exercício do poder discricionário evidenciado na obtenção de provas de incriminação de um indivíduo como de criminalização de alguma prática; (e) na determinação dos procedimentos de campo e questões de administração interna: são escolhas que envolvem decisões mais no nível de regulações de comportamentos dos policiais nas ruas, bem como questões relativas à manutenção de armamentos e equipamentos, preenchimento de formulários, etc.; (f) decisões sobre emissão de licenças e permissões: esta diz respeito à decisão de permitir a realização de eventos, de manifestações públicas ou venda de artigos específicos. Com esse aprofundamento dos níveis e dimensões em que a discricionariedade policial é exercida, pode-se inferir que há inumeráveis possibilidades para uma ação policial ser realizada sob completo domínio da sua discricionariedade sem que se obtenha qualquer controle sobre ela.

Segundo Bittner, essa área de decisões “invisíveis” está abrigada na discricionariedade do poder de polícia. O autor é enfático ao afirmar que o controle total sobre tal poder é inalcançável:

Não importa quão distante desçamos na hierarquia mais alta e mais detalhada de instrução formal, sempre permanecerá um degrau mais baixo para se ir, e nenhuma medida de esforço será bem sucedida para eliminar, ou mesmo diminuir de maneira significante, a área de liberdade discricionária do agente cujo dever é fazer com que as leis se ajustem aos casos. (BITTNER, 2003, p. 97) 
Ele reitera, portanto, que o poder discricionário da polícia é primordialmente intrínseco à natureza policial, tanto quanto inexorável. Já Goldstein (2003) compartilha dessa linha de análise, acrescentando ainda que há uma maior concentração de discricionariedade no nível operacional do trabalho de polícia, além de chamar atenção para a necessidade de organizá-lo:

\begin{abstract}
Estruturar a tomada de decisões da polícia tem outro valor além de assegurar a justiça no uso da autoridade do governo. A capacidade de um administrador de polícia administrar efetivamente sua agência e melhorar a qualidade do policiamento depende muito de ele ser capaz de exercer o controle efetivo sobre o infinito número de decisões tomadas constantemente pelo seu pessoal no nível operacional. Se o poder discricionário for estruturado, muitas das decisões que agora são tomadas nos níveis mais baixos da hierarquia na organização seriam tomadas em níveis mais altos e, portanto, baseadas em uma avaliação mais cuidadosa e mais defensável de considerações que competem entre si. Seria fornecida orientação ao pessoal operacional em áreas onde não há nenhuma. (GOLDSTEIN, 2003, p. 149)
\end{abstract}

Uma constatação deve ser feita: o poder discricionário policial deve ser admitido para que possa ser minimamente regulamentado e, por fim, controlado. Negá-lo não significa que ele deixe de existir, nem que o policial abra mão do seu exercício. Sem ele, o trabalho de polícia não seria possível. Porém, o controle do trabalho policial não depende do reconhecimento de sua discricionariedade. Mesmo sendo o poder discricionário inerente ao exercício das atividades policiais, e ainda sendo constatada a existência de campos de atuação policial sujeitos a poucas estratégias de controle, a polícia e o policial não devem ser poupados de medidas que visem ao ajustamento da prática policial às demandas da sociedade na qual eles estão inseridos. Muniz e Proença Jr. (2007) afirmam que o poder discricionário de polícia é proveniente da comunidade política, na qual a polícia está inserida e circunscrita. Segundo eles:

Pode-se dizer que a discricionariedade policial ecoa as discricionariedades saídas da polity, e isso de tal maneira que o conteúdo do que seja a ação policial não é redutível a um roteiro pré-determinado, nem mesmo à rigidez de princípios normativos. Ao contrário, o conteúdo da ação policial é determinado diante do contexto de cada situação particular, considerando as direções emanadas da polity quanto à oportunidade e à propriedade de um determinado curso de ação. A decisão sobre uma e outra pertence inescapavelmente ao policial individual, que depende de seu poder discricionário para poder realizar o seu trabalho. (MUNIZ e PROENÇA JR, 2007, pp. 42-43). 
A polícia não trabalha para ela mesma. Os objetivos dela devem estar em sintonia com as expectativas que a sociedade mantém sobre ela. Para tal, a forma encontrada de manter a relação entre a polícia e a sociedade dentro dos níveis desejados para a produção da ordem em uma comunidade deve ser estabelecida em aparatos de controle que resultem em responsabilização. O trabalho de Bayley colabora com a tarefa de criar formas de controle sobre a polícia. Ele propôs classificar os mecanismos de controle segundo o espaço que estão sendo desenvolvidos. Se o controle é realizado por estruturas exteriores à corporação policial, são denominados externos. Se a própria instituição policial cria e utiliza ferramentas de controle, são internos. Os mecanismos externos foram subdivididos em externos exclusivos e inclusivos. Os exclusivos são dedicados unicamente ao controle da força policial, ao passo que os inclusivos são direcionados à polícia e a outras instituições. Os mecanismos internos se subgrupam em explícitos e implícitos. Os explícitos são aqueles que declaradamente funcionam para controlar a ação policial como a supervisão de superiores, as normas disciplinares, entre outros. Aqueles considerados implícitos controlam de maneira indireta e não necessariamente intencional. Esse é o caso dos sindicatos, critérios de avaliação de desempenho, etc.

Ainda em seu estudo, Bayley indica:

[...] Que três fatores definem a mistura de controles externos e internos no que diz respeito à polícia. Eles são filosofia política (contratual/estatista), orientações normativas no sentido de relações sociais (individualismo/comunitarismo) $\mathrm{e}$ heterogeneidade social. (BAYLEY, 2006, p. 201).

Esses fatores são determinantes dos modos adotados por uma comunidade política para controlar a sua força policial. Em sociedades contratualistas e individualistas, há uma tendência maior para os mecanismos de controle externo, em razão da descrença no governo, em suas burocracias e em estratégias de autorregulação grupal. Em grupos mais comunitários, os mecanismos de controle interno são privilegiados, as práticas de autorregulação grupal 
estimuladas e há um respeito maior pelas burocracias, como também uma tradição de subserviência mais forte.

A heterogeneidade social se constitui em um fator estruturante do controle formal. Onde as diferenças sociais como de gênero, cor/raça, religião, entre outras, são acentuadas, há uma desconfiança da capacidade de autorregulação das instituições de autoridade. Onde esses grupos representativos de diferenças sociais estão engajados em movimentos de autodefesa, a confiança no governo e em seus processos regulatórios tende a ser reduzida. Todos esses elementos constitutivos do controle social levantados por Bayley configuram um cenário no qual o controle sobre as corporações policiais não é uma tarefa simples, à medida que reflete as visões da sociedade sobre sua própria tolerância em relação aos mecanismos de regulação social.

O controle da atividade policial demanda dar um passo para trás, dado que para se controlar qualquer atividade, é preciso saber como ela se realiza. Isso é evidente, porém no caso da polícia, torna-se complexo. Há um conflito sobre o entendimento do que venha a ser a função da polícia, e assim o que ela realiza ou deveria realizar. A prática do trabalho policial revela que os policiais fazem o que é denominado de manutenção da ordem e da paz na maior parte de seu tempo de trabalho, em vez da aplicação da lei. Aquilo que a polícia faz, o que se espera que ela faça e o que se diz que faz são questões distintas. Bittner reitera essa perspectiva dicotômica do trabalho policial, que se reproduz em sua organização interna e na definição de suas demandas e prioridades, ao concluir que:

A definição oficial do mandato da polícia é o de agente de aplicação da lei, ou seja, de policiamento. Suas demandas por recursos e apoio são justificadas pelas responsabilidades provenientes do fato de lidarem com crimes e outras violações da lei. A organização interna e a divisão de trabalho nos departamentos refletem categorias de controle do crime. O registro público de suas realizações e de seus fracassos é expresso nas estatísticas de criminalidade. $O$ reconhecimento por conduta meritória é dado por seus feitos de valor e engenhosidade de combate ao crime. Mas o trabalho no dia-a-dia da maior parte dos policiais tem muito pouco a ver com tudo isso. Esses policiais estão engajados no que é atualmente chamado, em geral, de 
manutenção da paz e da ordem, atividades essas em que é extremamente raro prender alguém. (BITTNER, 2003, p. 17)

O autor esclarece que o fato de a função policial não ser definida de acordo com a sua práxis coloca a polícia em uma posição de refém de sua própria mistificação. Sobre esse ponto, a sociedade e a polícia concordam que sua missão principal é o "combate ao crime". Essa imagem reflete um descompasso sobre o que se entende como sua missão e o que, de fato, é em consonância com que faz. Monet (2006) acrescenta que:

\begin{abstract}
Esta representação que a polícia faz de si mesma, e que os jornalistas, os romancistas ou os cineastas põem em cena, é ao mesmo tempo redutora e mistificadora. Redutora, pois a polícia de segurança trata muitos outros problemas sociais que não aqueles referentes à criminalidade, pondo ordem nos lugares das catástrofes, dos incêndios ou das explosões, escoltando as assistentes sociais ou os médicos quando é preciso arrombar a porta atrás da qual se encontra um doente mental ou uma senhora idosa moribunda, controlando o respeito às regras de trânsito, procurando uma criança perdida. Mistificadora, na medida em que faz crer que os policiais detêm o monopólio de tudo o que se refere, de perto ou de longe, à criminalidade e que existiriam equações tais como 'polícia = segurança' e 'mais polícia = mais segurança'. (MONET, 2006, p. 157-158).
\end{abstract}

Os fenômenos da mistificação e do reducionismo trazem graves consequências para a definição do mandato policial, conforme assinalou Bittner. Para que tal definição se realize, uma medida primordial deve ser tomada: esclarecer o que venha a ser o mandato de polícia. Um mandato, em geral, é definido como uma delegação de poderes para alguém que desempenhará funções especificadas em seus termos. O mandato policial se constitui em uma autorização ou uma delegação formal de poderes emitida por uma comunidade política para que a polícia possa realizar as atividades determinadas em seus termos, em conformidade com os objetivos definidos por ela mesma.

Há dois pontos importantes e diferenciadores do mandato policial. Primeiramente, a sua natureza pública e estatal. O mandato de polícia deve ser entendido como uma procuração pública, já que é outorgado pela coletividade, assim como, por ser gerido pelo governo, torna- 
se estatal. A segunda distinção se refere ao modo como ele se aplica. O mandato de polícia é estabelecido pela própria comunidade política sobre a qual o trabalho da polícia irá incidir. Para Muniz e Proença Jr.,

\begin{abstract}
A especificidade do mandato policial é a produção autorizada de enforcement em prol da paz social ou da sustentação das regras do jogo social estabelecidas pela polity, sem cometer violações ou violências. Trata-se, portanto, de produzir alternativas de obediência que garantam um determinado status quo desejado numa polity, com o seu consentimento e sob o império de suas leis. De forma sucinta, é isso que define o mandato policial: o exercício do poder coercitivo autorizado pelo respaldo da força de forma legítima e legal. (MUNIZ e PROENÇA JR, 2007, p. 38) [grifos do autor]
\end{abstract}

O mandato policial acaba por reforçar a evidente subordinação da polícia à comunidade política. Seus termos são definidos com base no que ela determina e espera que a polícia faça. Com o mandato policial constituído, tanto a sociedade quanto a polícia teriam clareza sobre o objetivo e o objeto do trabalho de polícia. Na verdade, no mandato encontram-se todos os elementos constituintes do poder de polícia.

Poder discricionário, autonomia, subordinação e controle são elementos constitutivos do poder de polícia. Em suma, a comunidade política outorga poderes à polícia para que ela mantenha a paz e a ordem dentro de um dado território, subordinada a um determinado governo, sob os limites da Lei. Sobre e para a própria comunidade política, o trabalho de polícia é desenvolvido. Os poderes concedidos à polícia são emanados da própria sociedade, cuja polícia é parte. Seu trabalho, invariavelmente, deve ser objeto de ajustes por parte de quem a investiu destes.

Portanto, o mandato define as "regras do jogo", em outras palavras: o que a polícia pode ou não fazer, como e quando sua força deve ser aplicada, e de quais maneiras ela deve fazer uso de seu poder coercitivo instrumentalizado no uso da força real ou potencial. Para que se possa garantir que a polícia cumpra aquilo para o qual foi designada, a comunidade política, então, cria ferramentas de controle do trabalho policial. O controle assim é exercido para manter 
a atuação policial dentro daquilo que dela se espera. Esse controle, quando bem exercido, deve delimitar ao máximo o uso da discricionariedade policial, levando-a a patamares ajustados às expectativas de sua atividade por parte da comunidade política.

Os aspectos do mandato policial podem ser aprofundados a partir de três instâncias: âmbito, alcance e contornos. (MUNIZ E PROENÇA JR, 2007). O âmbito do mandato policial pode ser entendido como a própria comunidade política. A incidência do mandato sobre seu objeto pode ser em três dimensões: i) territorial: a definição do âmbito ocorre pelo próprio recorte geográfico. A comunidade política se torna, portanto, o próprio âmbito da ação policial, seja em um bairro ou em um país. ii) tipo de evento: nesse caso, um tipo de crime cujos poderes policiais foram delegados para tratar especialmente dos mesmos, como crimes organizados ou crimes contra patrimônios ou crimes violentos. iii) grupos de pessoas: o mandato policial pode ser destinado a grupos étnicos, segmentos religiosos, imigrantes, representantes políticos ou qualquer outro.

No que diz respeito ao alcance, este define a divisão de competências entre organizações policiais concorrentes ou no interior de uma mesma organização. $\mathrm{O}$ caso brasileiro exemplifica a concorrência de distintas organizações policiais - polícias estaduais, federais e, mais recentemente, as guardas municipais desempenham funções de polícia - que realizam suas atividades para uma mesma comunidade política. $\mathrm{O}$ alcance de cada uma dessas organizações é distinto e, consequentemente, cada uma delas possui competências específicas. O caso colombiano se enquadra na hipótese de apenas uma organização policial em todo o país com competências específicas para cada setor/divisão interna. Esse arranjo possibilita que tipos de crimes ou especialidades policiais sejam assumidas por diferentes grupos.

Por fim, os contornos do mandato policial estão relacionados ao fazer policial, pois preconizam o modus operandi da polícia no desempenho de suas atividades para e na comunidade política. 
Nessa dimensão encontram-se as expectativas, os valores, os traços culturais de uma comunidade política. Nos contornos do mandato policial estão as suas outras dimensões. São nos contornos que discussões sobre "como" e "com quais meios" [grifo do autor] o trabalho de polícia deve ser realizado. Aí se encontra o núcleo de temas como direitos humanos, letalidade da ação policial, adequação do armamento ao seu mandato, enfim, temas decisivos para a polity. Nesse núcleo também são identificadas as discricionariedades policiais, onde o processo de tomada de decisão, continuadamente, vivifica as percepções da comunidade política traduzidas em escolhas na ação policial. Essa é a dimensão mais sensível das mudanças pelas quais as forças policiais passam historicamente. As mudanças nos contornos do mandato policial qualificam e atualizam a práxis policial, a dinâmica social da comunidade política e, por fim, sinalizam sobre a disponibilidade de ambas para o ajustamento e compartilhamento de ideais. (ANJOS, 2010, p.30).

A discussão sobre a profissionalização, as funções e o mandato de polícia estão em aberto, justamente porque esses temas são elementos constitutivos do poder coercitivo outorgado à polícia, para que a corporação incida sobre a própria sociedade outorgante naquilo que lhe é de inestimado valor: os seus direitos e liberdades. O desafio colocado à sociedade e à polícia está na conciliação de interesses, paixões e idiossincrasias para realizar em justa medida o exercício do poder e da autoridade policial de restringir, proibir, interromper ações contrárias ao bem geral. Entre os extremos conformados pela ausência de vigilância e tirania, deve estar a articulação entre expectativas e possibilidades da ação de polícia. Cabe reforçar que não há soluções prontas a ser aplicadas, mas, ao contrário, caminhos experimentais a ser trilhados. 


\section{AS POLÍCIAS}

A Policía Nacional de Colombia, na burocracia pública colombiana, encontra-se na estrutura do Ministerio de Defensa e possui a atribuição de realizar todo o trabalho de polícia no país, por ser a única instituição policial nacional. Nesse sentido, desempenha todas as atividades de polícia referentes aos diversos tipos ação. Isso significa que ela possui a atribuição de realizar: policiamento ostensivo, investigação criminal, perícia, salvamento e resgate, ações contra o crime organizado e narcotráfico, além de uma quantidade de especialidades determinadas segundo o tipo de criminalidade, como extorsão, sequestro, meio ambiente etc. Desse modo, atende às especificidades de polícia de ciclo completo, pois atua em todos os setores da segurança pública. Desde um comando nacional, todas as unidades policiais no território colombiano são coordenadas e monitoradas. Nos departamentos, cidades e regiões metropolitanas há comandos locais articulados à autoridade política máxima do poder executivo presente.

O departamento cujo trabalho de pesquisa foi realizado se chama Antioquia, cuja capital é Medellín. Nessa cidade, há unidades de polícia responsáveis pelo policiamento em território que lhe compete, que são as Estaciones de Policía, que desenvolvem suas estratégias de polícia de acordo com a dinâmica local. A divisão territorial de Medellín é feita por comunas, que são espaços territoriais conformados por bairros. Em cada comuna, há uma Estación de Policía. Na Comuna 13, onde a pesquisa se concentrou, a Estación de Policía San Javier realiza o policiamento local, sendo esta, então, a base local em que os policiais estavam alocados. Em cada Estación, há um comandante local e um quantitativo de policiais que cumprem as atividades administrativas e operacionais.

No Brasil, o modelo federativo prevê a independência administrativa dos entes federados e, por consequência, a consolidação de polícias de âmbito estadual. A Polícia Militar 
do Rio de Janeiro é definida como uma polícia ostensiva, sendo, portanto, responsável pelo policiamento ostensivo e as ações correspondentes e correlatas. No estado do Rio de Janeiro, a função de polícia judiciária é cumprida por outra instituição, a Polícia Civil, que não está vinculada à Polícia Militar. Ambas estão subordinadas ao poder executivo, e diretamente ligadas à Secretaria de Estado de Segurança (SESEG). As unidades policiais da PMERJ são chamadas batalhões de polícia, ou unidades especiais com nomenclaturas específicas. Os batalhões cobrem áreas geográficas predefinidas, conhecidas por AISP (Área Integrada de Segurança Pública). As atividades especializadas ou especiais estão a cargo de unidades específicas, como é o caso da $\mathrm{UPP}^{44}$ (Unidade de Polícia Pacificadora). A perspectiva pacificadora da PMERJ foi lançada em 2008 com a implantação da primeira UPP no morro Santa Marta. Essas unidades, desde então, são implantadas em favelas cariocas com objetivo de reduzir a incidência criminal, e proporcionar aos moradores condições de segurança. A perspectiva de campo com os policiais foi realizada na UPP Santa Marta.

\subsection{A TOMADA DE DECISÃO DO POLICIAL}

A tomada de decisão do policial que está nas ruas diante de uma situação que tem de intervir é prerrogativa da função. Reagir para prover resposta temporária e imediata é parte intrínseca do trabalho de polícia. Contínua e indefinidamente, os policiais são demandados a decidir qual tipo de medida deve ser empregada para a resolução do conflito em curso. Há de se considerar que a infinidade de eventos passíveis de ocorrer em um plantão policial é proporcional à quantidade e qualidade de situações que a interação humana pode produzir. Essa questão remete à reflexão ao mandato de polícia. $\mathrm{O}$ mandato policial se configura como um

\footnotetext{
${ }^{44}$ O governo do estado do Rio de Janeiro desenvolveu uma página de internet com informações, notícias e publicações sobre as UPP. Veja o link www.upprj.com
} 
assunto relevante e determinante para a prática policial. Grosso modo, é concebido com uma procuração pública que autoriza os policiais - primeiramente, as polícias - a fazer com que a ordem e a segurança sejam preservadas no convívio em sociedade. Dito assim, parece simples. No entanto, a empiria tem mostrado que a diversidade de ações, a escolha dos meios para interromper uma ação indesejada em curso e prover, desse modo, uma solução provisória e imediata é uma equação complexa e pungente.

Cabe ressaltar que a prática policial pode ser considerada como um indicador do grau de democratização de um país. As polícias, como braço armado do Estado, são empregadas para assegurar a democracia, bem como o exercício dos direitos cidadãos. Estando subordinadas à autoridade política, seus objetivos e métodos contam, assim, quais são as prioridades do governo (ou governante), ou onde e contra quem a força pública deve ser intensificada ou suavizada. Ainda mais reveladora é a prática policial no varejo da segurança pública, nas esquinas, ruas, vielas, favelas e recantos diversos. Em contato direto com a população, o policial nas ruas se torna acessível e disponível diuturna e permanentemente, a convite ou por imposição.

Portanto, os múltiplos, diversos e inusitados encontros e interações sociais conformam o campo de trabalho policial, no qual a tomada de decisão é realizada, no aqui e agora da emergência dos fatos, estabelecendo o pano de fundo para a resposta policial sob o império da lei e segundo o consentimento social. 


\subsection{Sobre a Policía Nacional de Colômbia - PONAL}

Para mi ser policía es el contacto con la comunidad, de pronto sea un poquito egocéntrico cuando lo diga pero a mí me gusta que la comunidad me vea reconocido y que me sientan a mi como un lugar donde apoyarse, como un amigo, como un líder como un compañero, a mí me gusta bastante, y siento que la policía es el lugar perfecto para cumplir estas funciones. (Patrullero)

Me gusta como soy yo policía, porque la policía tiene muchos problemas, pero me gusta mi labor como policía. (Patrullero)

¿La motivación mía para ingresar a la policía? Le podría decir que... pocas posibilidades de sobrevivir en este país a las personas pobres... tuve la posibilidad de ingresar a la policía porque es un trabajo estable ... desagradecido en algunos sentidos... acá en este país... pero... uno le coge amor al trabajo. (Patrullero)

Es como un sueño que tuve desde niño, desde niño tuve tíos policías, primos policías, y desde niño es como cuando le preguntan ¿usted que quiere ser cuando sea grande? "policía", y es como le he dicho a muchas personas a muchos amigos míos, de pronto a mi novia, que muchas veces uno agradece por cumplir el sueño que desde niño uno se prolongó, como hay personas que de pronto sueñan con ser doctores, con ser abogados y que nunca cumplen el sueño, yo cumplí el sueño mío que fue ser policía y eso quise ser. (Patrullero)

Para mi ser policía es un apoyo para la comunidad, si me entiende, es decir, lo que a uno le gusta, la motivación de uno salir todos los días, de pronto atender un caso de policía, ayudar a la comunidad a resolver problemas, para mi es eso ser policía. (Patrullero)

Eh... porque me gustaba y porque... viéndolo desde un punto de vista económico, ahora mismo el país está pasando por una crisis, no hay empleo así para mucha gente, entonces es una bueno opción la policía. (Patrullero)

Na estrutura do Ministerio de Defensa Nacional, estão as forças públicas colombianas:

Ejército Nacional, Armada Nacional, Fuerza Aérea e a Policía Nacional - todas com abrangência nacional. Seu comando central se localiza na capital do país, Bogotá. Na última constituição promulgada na Colômbia em 1991, o Estado colombiano se configurou como Estado Social e Democrático de Direitos. Nesse marco constitucional, a policía assumiu o papel de "preservar el orden público interno en sus condiciones de seguridad, salubridad, moralidad y tranquilidad para brindar a los ciudadanos" (Lineamientos Generales de Política para la Policía Nacional de Colombia, Tomo I, p. 12) 
A PONAL se concebe como um "cuerpo armado permanente de naturaleza civil"45, cujo “fin primordial es el mantenimiento de las condiciones necessárias para el ejercicio de los derechos y libertades públicas, y para assegurar que los habitantes de Colombia convivan en paz" ${ }^{46}$, orientando a sua prática por meio da adoção da doutrina militar. Os princípios são: vida, dignidad, equidade y coherencia, y excelencia. Já os valores institucionais: vocación professional, honestidad, compromiso, honor policial, disciplina e solidariedad. Em seus valores, a PONAL explicita a relevância da formação moral e ética do profissional.

Para a realização do policiamento colombiano, foram elaborados documentos com os conceitos e estratégias de implementação da política nacional de segurança. Nacionalmente, a Política de Seguridad Ciudadana ${ }^{47}$ se consolida por meio do Plan Nacional de Vigilancia Comunitária por Cuadrantes-PNVCC ${ }^{48}$. Segundo o seu próprio texto:

El Gobierno Nacional ha tenido a bien formular una nueva política de seguridad, denominada 'Seguridad ciudadana: una política nacional para la prosperidad democrática' la cual busca garantizar de manera integral la gestión pública de la seguridad ciudadana en el territorio nacional. En este sentido, el Plan Nacional de Vigilancia Comunitaria por Cuadrantes se constituye para la Policía Nacional en el eje fundamental de articulación para el cumplimiento de las metas institucionales alineadas con la política nacional de seguridad (p. 09).

O PNVCC tem como objetivos:

Alcanzar mayor interacción con el ciudadano; Contar con una respuesta oportuna a los requerimientos de la ciudadanía; Lograr una mejor integración con la comunidad; Generar corresponsabilidad frente a la seguridad ciudadana; Conocer detalladamente las causas y fenómenos que afectan el cuadrante" (p. 15).

\footnotetext{
${ }^{45}$ Todas as informações citadas podem ser encontradas na página de internet institucional da PONAL, www.policia.gov.co

${ }^{46}$ Fonte: página de internet da instituição.

${ }^{47}$ Este documento pode ser acessado na página http://wsp.presidencia.gov.co/SeguridadCiudadana/consejeria/Documents/Pol\%C3\%ADtica\%20Nacional\%20de\%20Seguridad\%20y\%20Convivencia\% 20Ciudadana-\%20Espa\%C3\%B1ol.pdf

${ }^{48}$ O PNVCC se encontra disponível no link http://www.policia.gov.co/portal/page/portal/HOME/concursosubintendente/Actualice_Conocimientos/5.\%20TOMO\%202.2.\%20Modelo\%20Nacional\%20de\%20vigilancia\% 20Comunitaria\%20p.pdf
} 
Em termos de foco, o PNVCC deixa claro que a estratégia privilegiada de atuação de polícia se aproxima dos princípios do policiamento comunitário, que tem seu eixo principal na interação comunitária para a resolução de conflitos e problemas comunitários, que são as atividades que mais ocupam o tempo de trabalho de policiais nas ruas. O organograma institucional apresenta a seguinte estrutura:

Figura 2: Organograma da PONAL

\section{Estructura actual de la Policía Nacional.}

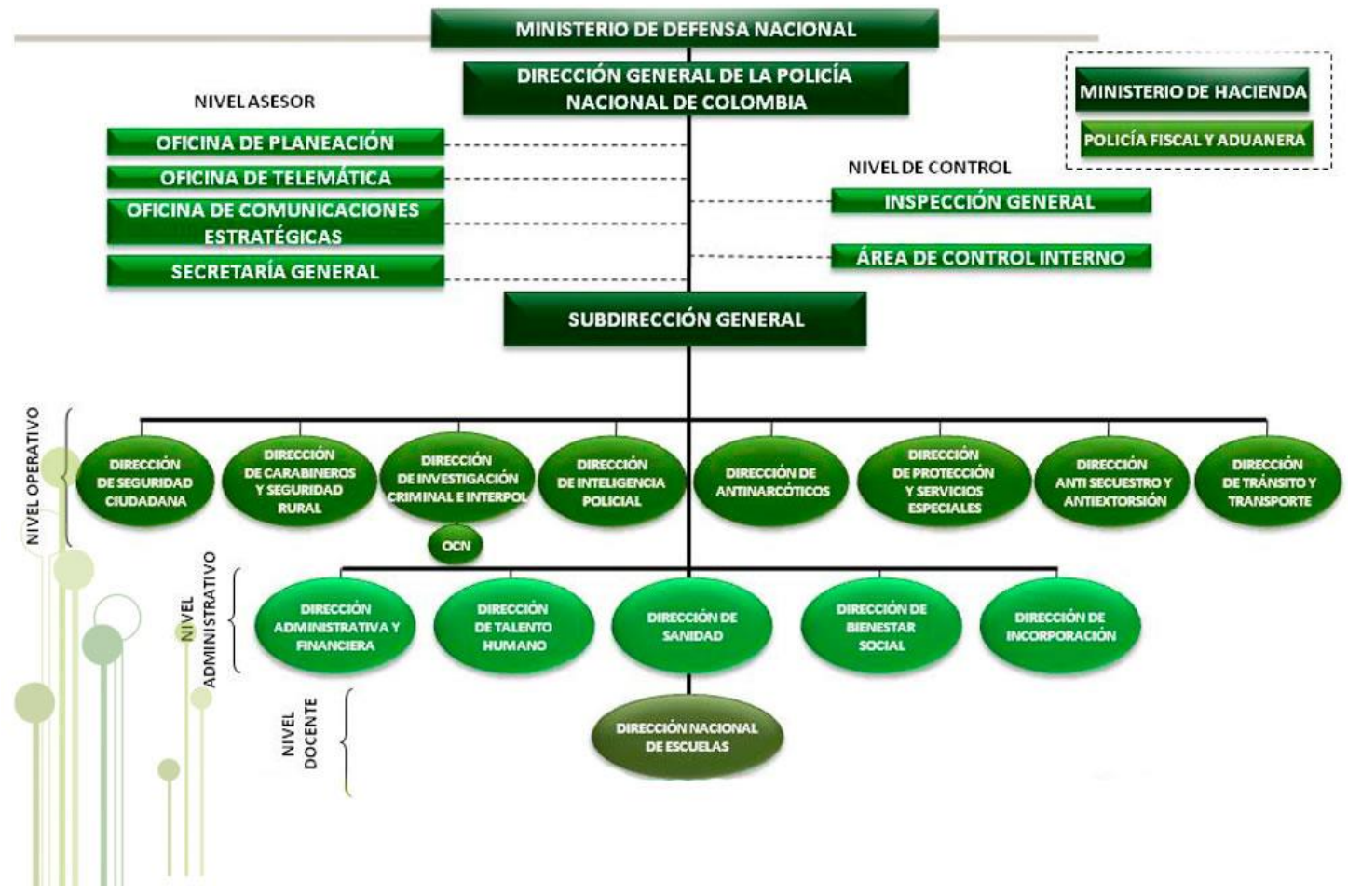

Fonte: Imagem retirada da página da Policía Nacional de Colombia.

Basicamente, a administração institucional se realiza a partir de uma divisão em níveis de gestão, que são cinco no total, a saber: níveis de gestão diretamente ligados à direção geral: 
assessoria e controle de pessoal; e osníveis de gestão diretamente relacionados à subdireção geral: operacional, administrativo e docente. No organograma, pode-se identificar que a atividade fim da polícia - o policiamento ostensivo - é controlada pela subdireção geral. As especialidades policiais são coordenadas por direções nacionais, em um total de sete. A direção nacional que importa, para o tema deste trabalho, é a Dirección Nacional de Seguridad Ciudadana, responsável por gerir as atividades de policiamento ostensivo. A partir dessa coordenação nacional, as diretrizes operacionais são definidas e implementadas no país. Outro aspecto importante da polícia colombiana seria sua natureza de polícia de ciclo completo. Por ciclo completo, entende-se uma instituição policial que realiza todas as atividades inerentes à função de polícia.

Em termos de armamento e uniformes, para cada tipo de atividade de polícia são definidos os meios e uniformes, equipamentos e tipo de transporte. A patrullaje é uma atividade de polícia ostensiva e os uniformes em todo país são iguais. Os meios de transporte podem ser motorizados - carro, motocicleta, monopatim, e outro tipos de veículos - ou cavalos ou bicicletas. Em terrenos de acesso difícil a meios motorizados, o policiamento se faz a pé. O tipo de armamento varia de acordo com a atividade. Para o policiamento ostensivo, utiliza-se a pistola automática Sig Sauer SP 2022.

A hierarquia policial colombiana se subdivide em quatro níveis ou escalões, nos quais estão agrupados as graduações de polícia, conforme descrito abaixo:

\section{Quadro 9: Divisão hierárquica da PONAL}

\begin{tabular}{|l|l|}
\hline \multicolumn{1}{|c|}{ Nível } & \multicolumn{1}{c|}{ Graduação } \\
\hline Oficiales Generales & General \\
\cline { 2 - 2 } & Teniente General \\
\cline { 2 - 2 } & Mayor General \\
\cline { 2 - 2 } & Brigadier General \\
\hline Oficiales Superiores & Coronel \\
\hline
\end{tabular}




\begin{tabular}{|l|l|}
\hline \multirow{4}{*}{ Oficiales Subalternos } & Teniente Coronel \\
\cline { 2 - 2 } & Mayor \\
\hline \multirow{5}{*}{ Ejecutivo } & Capitán \\
\cline { 2 - 2 } & Teniente \\
\cline { 2 - 2 } & Subtenente \\
\hline & Comisario \\
\cline { 2 - 2 } & Subcomisario \\
\cline { 2 - 2 } & Intendente Jefe \\
\cline { 2 - 2 } & Intendente \\
\cline { 2 - 2 } & Subintendente Fonte: PONAL \\
\cline { 2 - 2 } & Patrullero \\
\hline
\end{tabular}

Segundo as diretrizes policiais, as atividades de pratullaje podem ser executadas por qualquer uma das graduações de policiais do nível executivo. No entanto, os patrulleros são os que realizam essas atividades. Os demais do nível executivo acabam assumindo responsabilidades de microgestão, supervisão ou administrativas.

A política institucional da PONAL está elaborada em publicações divididas por temas. Em total, são quarenta documentos que compõem o conjunto de diretrizes e normativas internas. Todas as publicações são disponibilizadas em versão digital, disponível na página da intuição. Esse é um aspecto da sua organização que chama a atenção para a publicização dos documentos mais centrais para sua gestão em âmbito político e operacional. Por meio da página de internet, podem-se encontrar relatórios de prestação de contas produzidos anualmente, nos quais os cidadãos tem acesso, em linhas gerais, às ações e projetos implementados e seus resultados. Em termos de gestão e transparência, a PONAL indica que esforços têm sido empregados para que a instituição possa avançar no sentido de uma polícia democratizada. Evidentemente, a democratização das práticas policiais não pode ser reduzida à disponibilização de documentos em uma página de internet. Porém, no cenário da América Latina, a PONAL se destaca, de modo geral, por essas características.

Em termos de rotina de trabalho do policial, todas unidades policiais obedecem às mesmas diretrizes e normatização para a definição do plantão de trabalho. A escala de serviço 
é realizada segundo a concepção de ciclo de trabalho, o qual se estabelece por três turnos de trabalho de oito horas, me períodos distintos. O primeiro dia do ciclo é trabalhado pelo policial pela manhã. No segundo dia, no período tarde/noite. No último dia, no turno noturno. Terminado o ciclo completo, o policial goza de um dia e meio de descanso. Ao findar o descanso, recomeça o ciclo completo. Essa organização de trabalho impede o policial de desempenhar outra atividade laboral. O bico não faz parte da rotina profissional, e, por isso, estão dedicados integralmente à PONAL.

Em termos gerais, o policial, ao chegar na unidade de polícia para iniciar seu turno de serviço, cumpre a seguinte rotina: "Cuando recibo el turno, lo que hago es llegar en la estación, reclamo mi armamento, mi radio (...)" (Patrullero). Depois de o armamento e equipamento serem retirados do acautelamento para uso do profissional, todos seguem para uma reunião com o comando da unidade. Nessa reunião, são informados sobre as condições de segurança do local, metas e outras informações gerais. É um espaço em que o comando aproveita para passar a tropa em revista, verificando as condições de saúde, de vestimenta e qualquer outra demanda apresentada por algum policial. Após o momento de preleção em formatura, partem para os seus cuadrantes, em que se reúnem com a equipe que está deixando o plantão, visando a intercambiar informações. Para iniciar o plantão, fazem um "recogido" no território para verificar "si no hay novedades". As atividades que vão desempenhar durante o seu plantão estão predefinidas no TAMIR (Tabla de Acciones Minimas Requeridas).

No território colombiano, existem estruturas de gestão local da polícia subdivida em zonas chamadas metropolitanas, cuja responsabilidade se estende a vários municípios. A cidade Medellín, capital do departamento de Antioquia, onde a pesquisa de campo com os policiais foi desenvolvida, está localizada na Metropolitana del Valle de Aburrá, conhecida como MEVAL. Os comandos de polícias regionais de polícia respondem à autoridade política local. O comando da MEVAL, assim, está diretamente subordinado ao governador do departamento de Antioquia. 
$\mathrm{Na}$ verdade, os comandos regionais têm um chefe imediato, que são os governadores, e um chefe geral, que é o diretor geral da PONAL.

A cidade de Medellín se subdivide comunas -áreas geográficas compostas por bairros. No total, em Medellín, há dezesseis comunas. Para os fins dessa pesquisa, o trabalho de campo foi realizado na Comuna 13, e daqui e em diante, serão apresentadas informações sobre a unidade de polícia presente nessa comuna. Em cada comuna, há uma unidade de polícia responsável pela segurança e policiamento da área que lhe compete. $\mathrm{Na}$ Comuna 13, a Estación de Policía San Javier é responsável por essa região, contando com um efetivo de 298 policiais, distribuídos da seguinte maneira:

\section{Quadro 10: Quantitativo de policiais da Estación San Javier}

\begin{tabular}{|c|c|c|c|}
\hline Grau hierárquico & Quantitativo Total & Homens & Mulheres \\
\hline Mayor & 1 & 1 & - \\
\hline Sargento & 3 & 13 & - \\
\hline Intendente & 13 & 29 & 5 \\
\hline Subintendente & 29 & 247 & $\mathbf{5}$ \\
\hline Patrullero & 252 & $\mathbf{2 9 3}$ & \\
\hline Total geral & $\mathbf{2 9 8}$ & & \\
\hline
\end{tabular}

Fonte: PONAL

A entrada dos policiais na PONAL ocorre por meio de processos de seleção distintos para patrulleros e oficiais. A dupla entrada se desdobra em processo de formação separados em escolas especializadas para formação de patrulleros e de oficiais. Uma especificidade nesse processo formativo é a separação entre mulheres e homens. Há escolas somente para mulheres patrulleras, ao passo que, para oficiais, mulheres e homens podem frequentar o mesmo espaço. 
O curso de formação para patrulleros e oficiais é custeado pelo estudante. Além do curso, os estudantes em formação devem providenciar objetos de uso considerado pessoal, como colchão, lençóis, toalhas e artigos de higiene pessoal. As escolas oferecem como parte de sua estrutura física salas de aulas, biblioteca, espaços de estudo, espaços de lazer, etc. A alimentação dos estudantes é responsabilidade das escolas. Em termos de custo de formação, o curso de oficiais tem um valor mais alto e duração de três anos. Se o estudante já possuir formação universitária, a formação se reduz a um ano. A duração prevista de um curso de formação de patrulleros é um ano. No entanto, se o estudante já tiver prestado serviço militar, esse tempo é reduzido para seis meses.

Os sujeitos dessa pesquisa foram os patrulleros e, por essa razão, o conteúdo do curso de formação privilegiado foi para esse grupo. Como já mencionado, a natureza nacional da PONAL implica formulação de diretrizes nacionais para todos os aspectos organizacionais e de formação. Nesse sentido, a formação de patrullero é definida pela Dirección Nacional de Escuelas para todas as escolas do país.

O programa de Formação de Patrulleros (ver Anexo III) está organizado por temas, que são chamados de áreas de concentração: Policial, Comunicação Oral e Escrita, Jurídica Fundamental, Jurídica Especial, Desenvolvimento Humano, Complementar e Flexível. Os conteúdos abordados na área policial ocupam $57,53 \%$ do programa de formação. Já os conteúdos jurídicos nas duas áreas representam 19,18\%, enquanto os de desenvolvimento humano, 10,96\%. A área complementar e flexível contém as disciplinas optativas, escolhidas pelo estudante diante dos diversos assuntos oferecidos a cada semestre. Essa área equivale a $10,96 \%$ do programa de formação.

Uma breve analise do conteúdo programático dos patrulleros revela que a carga maior de estudo se concentra nos temas considerados assunto de polícia, que são: doutrina e cultura policial; serviço de polícia; ordem unida; uso adequado da forca, investigação criminal; 
estatística aplica ao serviço de polícia; segurança integral; segurança de vias; fundamentos e uso de armas de fogo; operações urbanas e rurais. Para o trabalho de patrullaje nas ruas, de acordo com o foco da formação desses profissionais, são os conhecimentos necessários para o exercício das atividades de polícia. A segunda tônica da formação está centrada em disciplinas do campo jurídico, mas que, em termos quantitativos, distam consideravelmente da maior área, que é a de temas policiais, aproximando-se da terceira, que é desenvolvimento humano. Essas duas últimas assumem peso semelhante, o que pode significar que esses dois grandes temas estão em grau de relevância muito próximos. Nesse caso, a concepção do trabalho de polícia como uma função de law enforcement não se verifica, segundo o programa de formação atualmente aplicado. A terceira área de concentração de disciplinas é a de desenvolvimento humano, a qual trata de assuntos como ética, bilinguismo, pesquisa sociológica e convivência, cultura da legalidade, resolução de conflitos, ambientes educacionais saudáveis.

\subsection{Sobre a Polícia Militar do Estado do Rio de Janeiro - PMERJ}

Pô, ser policial para mim é... Na verdade, o que eu falo né, pra mim eu tô de férias todo dia porque eu faço o que eu gosto, o grande problema é que temos muita deficiência, tem muito o que melhorar, é tudo muito no papel ainda, vai caminhando tudo muito devagar, mas pra mim é tudo... Eu sou feliz no que eu faço. (Policial UPP)

Bom... eu... meu sonho é ser bombeiro... minha família toda é militar, por parte de pai, todos os homens eram da Marinha. Eu servi o exército, mas não queria ir pra Marinha, eu queria ser bombeiro, tentei fazer a prova do bombeiro várias vezes, só que eu não consegui... e... passou um tempo, militar tal, achava interessante a profissão de polícia. Posso falar que eu achava interessante porque eu não sabia o que realmente acontece né... Mas assim, você vê algumas coisas na televisão, acha que vai ser assim, que a gente vai conseguir resolver tal, e é uma coisa totalmente diferente, né? Então, a gente não faz os serviços investigativos, como a gente olhava nos filmes. (Policial UPP).

Vou te falar que, primeiro: por gostar da área militar, independente, Exército, Marinha ou outra força militar, por gostar. Uma oportunidade surgiu na área da polícia, o campo se abriu pra polícia, surgiram vagas, achei a oportunidade e precisando também, estabilidade profissional. E me senti bem nessa área. Então foi motivação de crescer, eu queria crescer. (Policial UPP).

Quando eu entrei eu sempre gostei do militarismo... Eu escolhi a polícia militar porque é das Forças Armadas, das forças auxiliares, ela era uma força auxiliar que tinha mais contato com o público e eu gosto de gente, eu gosto de estar ajudando diretamente as pessoas, diferente das forças armadas... Então, eu consegui juntar as duas coisas: 
trabalhar diretamente com o público, e dentro do militarismo. A princípio foi isso, e depois que eu entrei e conheci melhor a polícia militar, as visões dos valores, eu percebi que era exatamente o que eu buscava. (Policial UPP).

Eu acho que a polícia militar tá mudando muito né, já mudou com o avanço dos Direitos Humanos, da própria tecnologia, eu acho que mudou o pensamento do público interno, com a forma de lidar com cidadão e eu espero que isso só aumente na Corporação, que o policial ele passa a pensar de uma forma mais humana, de uma forma que colabore mais com cidadania e respeito. (Policial UPP).

Bom, ser policial militar é gratificante em algumas partes. Quando a sociedade compreende aquilo que a gente faz, é muito prazeroso, quando a gente ajuda alguém. Muitos policiais fazem parto, então isso é gratificante, ajudar alguma pessoa que foi roubada, recuperar um veículo, isso é gratificante. Então assim, ser policial militar, tem vários tópicos, neh? Mas assim, ser policial militar nessa parte é gratificante, mas se a gente erra, entendeu, a gente não é visto muito bem, então isso decepciona muitas vezes o policial militar. (Ppolicial UPP).

Entre as demais polícias militares do Brasil, a PMERJ é considerada a matriz de todas. Da mesma forma, a sua concepção fundante é compreendida como o embrião de todas as polícias brasileiras, já que foi a primeira a ser criada. Assim, a posteriori, serviu como referência para as outras. Desde a sua criação, como uma corporação que viria a ser atualmente a PMERJ, foram realizadas inúmeras alterações no formato organizacional, nos objetivos, na composição dos seus profissionais, na esfera legal do o Brasil colonial até a Constituição de 1988, em sua inserção na estrutura dos governos, na disciplina e regulamento internos, bem como nas formas e mecanismos com os quais a instituição lida com a sociedade. Há uma literatura ${ }^{49}$ acessível sobre a história da colonização brasileira, que pode servir de base para a contextualização do momento histórico da criação do primeiro corpo de polícia no Rio de Janeiro e do Brasil.

As polícias militares brasileiras eram aquarteladas até o ano de 1967 e desempenhavam funções auxiliares ao exército para a manutenção da ordem e segurança interna. Nesse período,

\footnotetext{
${ }^{49} \mathrm{O}$ debate sobre o tema da instituição do Estado Brasileiro poder ser encontrado em Raízes do Brasil (HOLANDA, 2009); História da História do Brasil (RODRIGUES, 1979); Casa Grande e Senzala (FREYRE, 1985); Os Bestializados (CARVALHO, 1987). Sobre o contexto histórico da criação dos primeiros serviços de polícia, ver Bretas (1997), e Holloway (1997).
} 
o policiamento era delegado à Polícia Civil, à Guarda Civil, à Guarda de Vigilância, à Polícia de Trânsito, entre outras. Nesse sentido, a polícia militar se mantinha em um ócio improdutivo, já que ficavam à espera de ser demandada para entrar em ação por tempo indefinido.

Na gestão pública fluminense, a polícia militar está sob a estrutura organizacional da SESEG, que coordena a política de segurança estadual. Diferentemente da Colômbia, no Brasil as polícias não são consideradas polícia de ciclo completo, pois subdividem o trabalho de polícia entre algumas instituições. Em âmbito estadual, as polícias militar e civil são encarregadas de realizar as atividades de polícia judiciária e ostensiva, segundo a competência legal de cada uma.

Atualmente, a PMERJ está organizada de acordo com o organograma abaixo. 
Figura 3: Organograma da PMERJ.

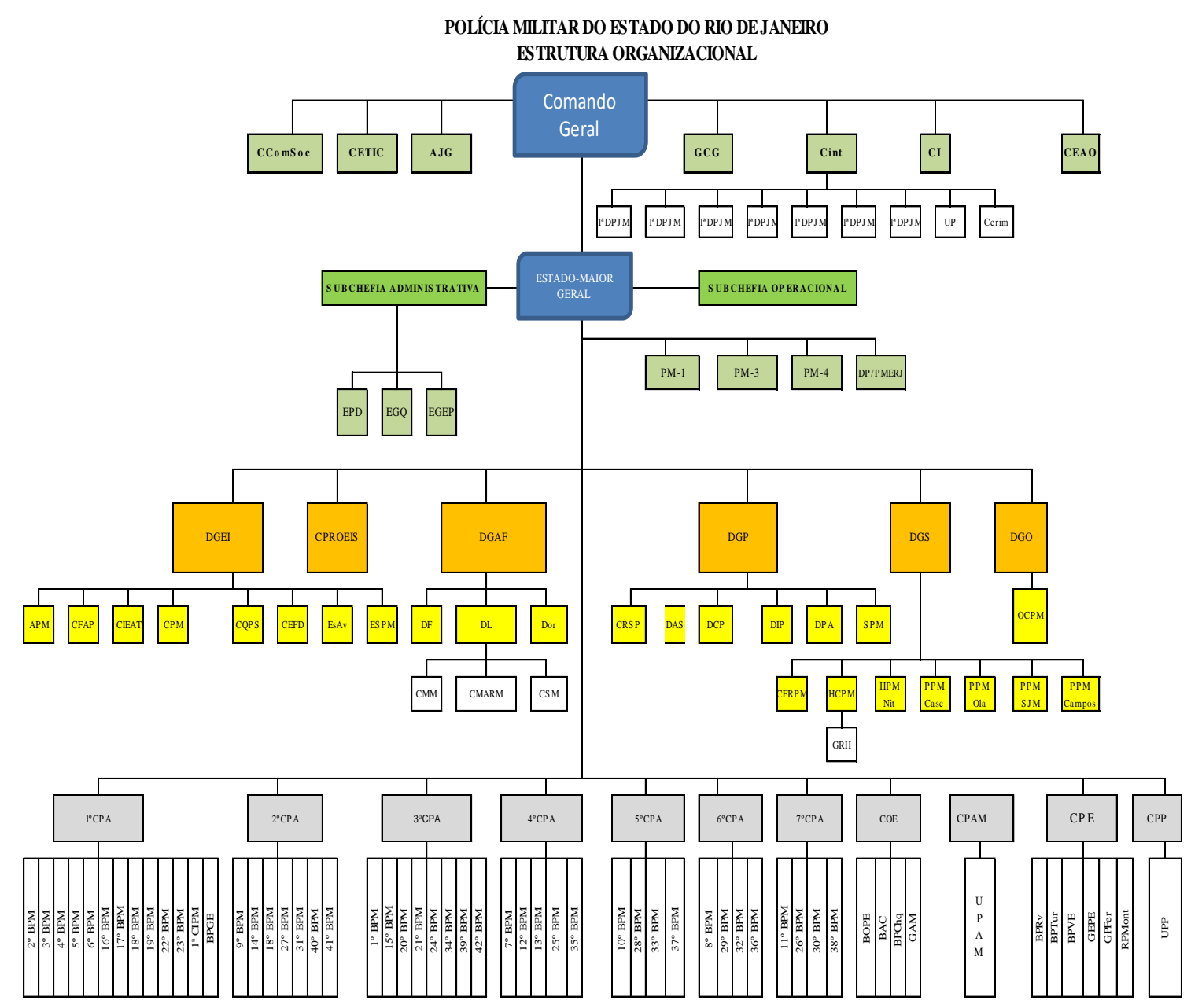

Fonte: Informação cedida pela PMERJ.

Segundo essa estrutura, no comando geral da instituição estão alocadas as instâncias de assessoria e ajudância. Na configuração atual, foi realizada uma mudança em relação às gestões anteriores, no que tange o Estado-Maior Geral. Essa esfera de poder foi subdividida em subchefias administrativa e operacional. Com isso, a gestão das atividades administrativas e operacionais são coordenadas por chefias distintas. 
A hierarquia da polícia militar está dividida em círculos, o que seria como níveis que agrupam as categorias. Nesse caso, são dois grandes círculos, nos quais estão os oficiais e os praças, respectivamente, conforme ilustrado no quadro abaixo.

\section{Quadro 11: Divisão hierárquica da PMERJ}

\begin{tabular}{|l|l|}
\hline \multicolumn{2}{|c|}{ Círculo de Oficiais } \\
\hline \multicolumn{1}{|c|}{ Categorias } & \\
\hline Superiores & Costos \\
\cline { 2 - 3 } & Tenente coronel \\
\cline { 2 - 3 } & Major \\
\hline Intermediários & Capitão \\
\hline Subalternos & $1^{\circ}$ Tenente \\
\cline { 2 - 3 } & $2^{\circ}$ Tenente \\
\hline Praças Especiais & Aspirante oficial \\
\cline { 2 - 3 } & Aluno oficial \\
\cline { 2 - 3 } & Cadete \\
\hline \multirow{5}{*}{$\begin{array}{l}\text { Subtenentes e } \\
\text { Cargentos }\end{array}$} & Subtenente \\
\cline { 2 - 3 } & $1^{\circ}$ Sargento \\
\cline { 2 - 3 } & $2^{\circ}$ Sargento \\
\hline & $3^{\circ}$ Sargento \\
\hline
\end{tabular}

Fonte: PMERJ.

Em termos de uniforme, as polícias militares do Brasil têm autonomia para desenvolver os tipos de uniformes para cada atividade ou especialidade. Na PMERJ, o uniforme tradicional padronizado para o policiamento ostensivo se chama MUG. Em termos de armamento, a pistola calibre .40 (lê-se ponto quarenta) é utilizada para o serviço de patrulhamento. No entanto, no 
contexto carioca de guerra, torna-se uma justificativa o uso de armas alto potencial ofensivo e calibre, como carabinas e fuzil, nos calibres 5,56 e 7,62, respectivamente.

Os meios de transporte dos policiais, majoritariamente, são motorizados: diversos tipos de veículos, motocicletas. Em áreas turísticas ou de difícil acesso, também são utilizadas bicicletas. Para patrulhamentos específicos se usam cavalos, como em estádios e outros locais e fins. O policiamento tradicional a pé é realizado generalizadamente no território fluminense.

Em 2012, a PM deu início a um projeto de reformulação estratégica, que resultou na criação de uma nova proposta chamada Mapa Estratégico da PMERJ, implementada a partir de 2013, com fim previsto para 2018 (ver Anexo IV), provocado por um processo de realinhamento por parte da SESEG. A nova proposta adotou como valores: "Hierarquia e disciplina; Preservação da vida e dignidade humana; Respeito ao interesse público, ao policial e ao cidadão; Profissionalismo com reconhecimento do mérito; Transparência". E incorporou como missão "Promover a segurança cidadã, servindo e protegendo a sociedade no Estado do Rio de Janeiro" (p. 03).

No campo da filosofia de trabalho de polícia, com a implementação do Mapa Estratégico, a PMERJ valeu-se do conceito de polícia de proximidade ${ }^{50}$. Anteriormente a essa medida, havia algumas filosofias norteadoras da prática policial implementadas de maneira fragmentada e recortada, pois correspondiam à estratégia do local em que estava implantada a unidade em questão. Uma dessas foi a polícia comunitária, colocada em prática em alguns bairros-pilotos da cidade, para posteriormente ser estendida a outras regiões da cidade. Por alguns anos, essa filosofia predominou em termos de inovação do trabalho de polícia. Inspirados e derivados da experiência do policiamento comunitário, alguns tipos de policiamento em áreas especiais foram desenvolvidos, como o GPAE (Grupamento de

\footnotetext{
${ }^{50} \mathrm{O}$ documento de criação de unidades de polícia de proximidade, disponibilizado pela PMERJ, está disponível no Anexo V.
} 
Policiamento em Áreas Especiais), substituído pela polícia pacificadora, materializada nas UPP. Como áreas especiais, eram intitulados os espaços territoriais, popularmente chamados de favela. No período do GPAE, as favelas eram denominadas de áreas especiais, ao passo que, no período atual de UPP, as mesmas áreas passam a ser intituladas de comunidades. Todo esse esforço foi para suavizar o uso do termo favela, e assim assumir uma postura política politicamente correta em um espaço de tempo definido - em um explícito exercício de eufemismo -, que serve para se reinventar a cada nova gestão de governo, já que as mesmas árease realidades se perpetuam.

A polícia de proximidade foi instituída oficialmente pela Instrução Normativa $n^{\circ} 022$ da PMERJ, de 12 de fevereiro de 2015. O texto da normativa define, do seguinte modo, o conceito de polícia:

\begin{abstract}
(...) Uma filosofia na qual policiais e cidadãos dos mais diversos segmentos societais trabalham em parceria, desenvolvendo ações em regiões territoriais específicas, promovendo o controle das questões relacionadas ao fenômeno criminal. Está alicerçada sob os seguintes princípios: Prevenção, Descentralização, Proatividade e Resolução Pacífica de conflitos. Sua operacionalização consiste nas ações de polícia baseadas na Aproximação, Presença, Permanência, Envolvimento e Comprometimento do policial no seu ambiente de trabalho, objetivando a redução dos indicadores de violência e criminalidade e a melhoria da qualidade de vida das pessoas naqueles locais (p. 3).
\end{abstract}

A definição de polícia de proximidade apresentada pela polícia contém os elementos centrais do policiamento comunitário apresentados por Skolnick \& Bayley (2006), ou seja, as características e filosofia da polícia comunitária são preservadas, mas com nova roupagem. $\mathrm{Na}$ prática, isso pode ser interpretado como mais do mesmo, ou como uma nova forma de fazer o que já se fazia, mudando-se de nomenclatura como tentativa de inovar. Indubitavelmente, há um impacto político e midiático produzido pelo novo. Especialmente no caso da relação polícia e população de favelas cariocas, a nova proposta pode ser uma ponte para a credibilidade e legitimidade da ação de polícia, ambicionada pelos governantes, e até mesmo pela polícia. 
Nesse sentido, a polícia de proximidade atende a objetivos múltiplos e vem sendo apresentada à sociedade como uma metáfora da paz.

\begin{abstract}
Proximidade serve como uma palavra-síntese das expectativas de transformação de mentalidades e práticas a serviço de uma visão ampliada de segurança pública. Emerge na linguagem como uma palavra-performance que cria e dá vida à realidade que nomeia no ato mesmo de sua enunciação. De fácil assimilação ela cumpre a função de comunicar tudo o que se acredita que seja ou possa vir a ser. E a proximidade pode ser mesmo um tudo: uma grande metáfora que compreende atos, fatos, intenções, valores, expectativas. (MUNIZ \& MELLO, 2015, p. 51).
\end{abstract}

O ingresso na instituição se dá por meio de concurso público diferenciado, sendo separado para os praças e para os oficiais. Para oficiais, o curso tem duração de três anos. Diferentemente da PONAL, na PMERJ, os estudantes têm seus cursos financiados pelo governo estadual, para ambos os grupos. A formação, assim como os cursos de aperfeiçoamento, dos que ingressam na instituição para o posto de soldado, na PMERJ, é desenvolvida Centro de Formação e Aperfeiçoamento de Praças 31 de Voluntários (CEFAP). A formação de soldados é desenvolvida para homens e mulheres, em um mesmo espaço físico de ensino, no entanto, com dormitórios separados. O processo de formação profissional das polícias militares brasileiras vem sendo orientado pela Matriz Curricular Nacional para a Formação em Segurança Pública $^{51}$, elaborada pela Secretaria Nacional de Segurança Pública (SENASP). A última versão desse documento foi elaborada em 2009. Neste, há um esforço de padronização da formação para esses profissionais em âmbito nacional, de maneira a contemplar temas importantes para a prática policial cidadã.

A adesão ao currículo nacional por parte dos estados não é obrigatória, considerando-se que os entes federativos possuem autonomia administrativa para adotar um modelo próprio. No Rio de Janeiro, a SESEG, com base na matriz nacional, desenvolveu em 2012 o documento

\footnotetext{
${ }^{51}$ A versão de 2014 da Matriz Curricular Nacional pode ser encontrada no link http://www.justica.gov.br/central-de-conteudo/seguranca-publica/livros/matriz-curricular-nacional_versaofinal 2014.pdf/view
} 
chamado Currículos para os Cursos de Formação Soldados, Cabos e Sargentos (ver Anexo VI), com a finalidade de alinhar a formação de praças às diretrizes nacionais, com o objetivo geral de "criar condições para que os policiais em formação possam: ampliar conhecimentos; desenvolver habilidades técnicas e cognitivas; e fortalecer atitudes pessoais e corporativas necessárias à sua atuação como operadores de segurança pública” (p. 11).

Em termos de conteúdo, a formação de praças se concentra em três grandes temas organizados em módulo comum, módulo profissional, módulo jurídico e módulo complementar. O objetivo do módulo comum é oferecer uma base universal de disciplinas, que são oferecidas em todos os cursos de formação do CEFAP, cuja disciplina mais relevante, no que se refere à democratização da prática policial, seria Direitos Humanos. Nesse módulo, essa disciplina ocupa 16 horas/aula, sendo esta a segunda menor carga horária em relação ao total de 184 horas/aula. O conteúdo do módulo profissional conta com um total de 430 horas/aula, ocupando a maior carga horária do programa curricular. Nesse módulo, as disciplinas com maior carga horária são Instruções Práticas de Ações Táticas (80 horas/aula), Armamento e Policiamento Ostensivo, sendo cada uma dessas duas últimas disciplinas com 50 horas/aula. O módulo jurídico trata de algumas especialidades jurídicas e tem um total de 128 horas/aula. $\mathrm{O}$ módulo complementar contém disciplinas que não contam, obrigatoriamente, com conteúdo teórico, como estágio, formaturas, etc. Após a adoção da filosofia de polícia de proximidade, esse currículo foi revisado para incluir uma disciplina que contemple esse conteúdo.

Para cumprir com os fins da pesquisa, a partir desse momento serão apresentadas informações sobre a unidade polícia na qual estavam os policiais entrevistados: UPP Santa Marta. Segundo dados fornecidos pela PMERJ, o efetivo de policiais na UPP era composto conforme o quadro a seguir. 


\section{Quadro 12: Quantitativo de policias - UPP Santa Marta}

\begin{tabular}{|c|c|c|c|c|c|c|}
\hline & $\mathbf{1}^{\mathbf{0}}$ Ten & SubTen & $\mathbf{3}^{\mathbf{o}}$ Sgt & Cabo & Soldado & Total \\
\hline Masculino & 1 & 3 & 8 & 6 & 90 & 108 \\
\hline Feminino & 1 & & & & 14 & 15 \\
\hline Total & 2 & 3 & 8 & 6 & 104 & 123 \\
\hline
\end{tabular}

De acordo com essas informações, o maior quantitativo de policiais está empregado em atividades de policiamento, pois são os soldados que fazem, majoritariamente, o policiamento ostensivo. Não há impedimentos normativos para que os demais praças executem atividades de policiamento ostensivo. Porém, de fato, esses são destinados a atividades administrativas ou de microgestão.

A UPP Santa Marta, na ocasião da pesquisa, estava subordinada administrativamente ao $2^{\circ}$ BPM, o que significa que, por exemplo, equipamentos, armamentos e viaturas são guardados e acautelados por essa unidade. Como a sede da UPP está localizada na parte alta do morro, o acesso se faz, principalmente, a pé. De carro se chega próximo, por uma via externa ao perímetro do morro.

Nesse sentido, a rotina de início dos plantões de trabalho, necessariamente, inicia-se no $2^{\circ}$ BPM. Nas suas instalações, vestem o uniforme e retiram o armamento na RUMBI (depósito onde o armamento e munição ficam acautelados), além dos demais equipamentos que usam. Em seguida, tomam um transporte próprio da polícia, para então chegar à UPP e iniciar o plantão. As atividades do dia estão descritas na ordem de serviço, documento descrito do trabalho a ser realizado no plantão pela equipe. Ao término do expediente, refazem essa mesma rotina para devolver todo o material de trabalho utilizado ao $2^{\circ}$ BPM. Depois de chegarem na UPP, verificam as ordens de serviço do dia para saber o que terão de fazer. 
repente podem pedir um apoio em outra unidade que esteja precisando. (Policial UPP).

O trabalho pode ser realizado em grupos de quatro, três ou dois policiais, segundo o tipo de atividade que realizam. Em geral, fazem a patrulha no morro, intercalando com os momentos de descanso. A geografia do Santa Marta exige do policial um esforço físico diário mais intenso, já que devem se deslocar por escadarias íngremes ou zonas de mata com um terreno acidentado. As escalas de plantão policial são variadas. As equipes de trabalho podem trabalhar em regime de 24 horas por 12 de descanso, 12 horas de trabalho por 24 horas de descanso, 12 horas de trabalho por 48 de descanso, seis dias (horário de expediente) por um dia de descanso, ou qualquer outra escala que atenda às necessidades do trabalho a ser realizado. 


\section{PERCEPÇÕES SOBRE O TRABALHO DE POLÍCIA}

O trabalho policial possui características e especificidades que conformam a prática policial, assim como essa mesma prática propõe as características e especificidades do trabalho de polícia. Considerando-se as atividades de polícia realizadas pela PONAL e pela PMERJ, faz-se necessário apresentar as características de ambas que dão o contorno à prática policial dos seus profissionais.

Na Colômbia, o fato de a PONAL ser uma instituição nacional lhe confere algumas características mais próximas às forças armadas brasileiras, como um comando geral nacional, uma matriz de formação e treinamento única, um uniforme único para a atividade de patrulha, e assim por diante. O ponto mais importante destacado nas entrevistas foi o deslocamento dos policiais para qualquer cidade do território nacional. O policial colombiano, ao ingressar na polícia, já sabe de antemão que será enviado a uma cidade distinta da sua de origem. Essa, na verdade, pode parecer ser uma questão simples do ponto de vista organizacional, porém, no que diz respeito à percepção policial, converteu-se em um dos fatores de maior impacto na prática policial. O distanciamento da família, dos amigos e de uma realidade próxima, conhecida e controlável no sentido de segurança e de riscos, torna-se um fator decisivo para esses profissionais. Foi quase unânime nas entrevistas que essa condição de afastamento dos laços afetivos tem pelo menos dois impactos imediatos: a necessidade de restabelecer laços de solidariedade e vínculos de amizades com os colegas de profissão; e o trabalho ocupar um espaço de grande dimensão, pois praticamente se transforma na atividade principal - e em muitos casos na única atividade - desses profissionais. Saudade, tristeza e solidão foram as palavras que expressaram os entrevistados ao serem perguntados se estão satisfeitos com a profissão que escolheram. A despeito de ser unânime a afirmação de estavam, sim, satisfeitos, foi consensual a percepção sobre o impacto emocional que a situação cotidiana lhes causa. 
Es duro desprenderse uno de la familia. (...) Con el tiempo aprendemos a estar lejos. (...) Con el tiempo voy a poder solicitar un traslado para estar más cerca a mi familia. (Patrullero).

La seguridad... es complicada porque... yo vengo de una ciudad que es muy tranquila. Usted puede ir a Tunja y usted a cualquier hora se puede movilizar en cualquier parte y, pues o $100 \%$ totalmente seguro pero es una ciudad muy tranquila que no tiene mucho conflicto. Mientras que llegamos acá y encontramos las comunas, las pandillas, los grupos delincuenciales... y yo creo que usted se ha dado cuenta si ha transitado por Medellín que hay lugares donde hay mucho habitante de la calle, mientras que en mi ciudad no lo hay, o sea de ese número como acá no lo hay. (Patrullero).

(...) hay dos tipos de dificultades diría yo, primera que como policías creas en amigos en la calle.. Y segunda la lejanía, la distancia a una vida emocional directamente con personas normal, mi familia, compañera sentimental no tengo estoy hablando de casos de policías cierto, compañera sentimental, hijos, la relación con ellos, eso me parece muy importante. (Patrullero).

Como dito, há a necessidade de se estabelecerem novos vínculos ou uma 'irmandade' entre os que estão no mesmo nível hierárquico. No caso dos entrevistados da PONAL, esses policiais são patrulleros - o grau hierárquico situado na base da polícia, bem como o primeiro ocupado ao se ingressar na organização.

En momento una relación buena, porque es como una familia. Lo que pronto pase a un compañero uno le duele. Porque un día, mañana necesito ellos y ellos necesitan de uno. (Patrullero).

Con los compañeros de trabajo en el mismo grado... es excelente, más que todo acá se brinda mucho el apoyo, es como una familia. (Patrullero).

En el momento es una relación buena, que es como una familia, lo que de pronto le pasa a un compañero a uno le duele, a uno le duele que un compañero de pronto le pase algo, entonces, uno siempre trata de tener una buena relación, porque el día de mañana necesita a ellos y ellos necesitan de uno. (Patrullero).

Quase na mesma proporção em que os laços de amizade se apertam entre os policiais, as relações de confiança também são criadas. Um trabalho com risco de morte permanente demanda desses profissionais confiança em seus colegas. Essa confiança é funcional, já que lhes garante proteção no desempenho de suas atividades, pois o trabalho de polícia na Colômbia 
é realizado ao menos em dupla ou em grupos maiores. Assim, torna-se uma necessidade confiar naqueles com os quais se dividem as responsabilidades inerentes à execução do trabalho.

Si. La relación con los compañeros es bien. Nosotros aquí tenemos presente que el trabajo en equipo es fundamental. El trabajo en equipo es fundamental. Aquí nosotros sabemos que estamos poniendo en juego muchas veces la vida de nosotros y nosotros no podemos dejarnos desfallecer ni dejarnos... dormirnos cuando a un compañero le están haciendo algo. No. Toca inmediatamente ayudarlo, colaborarle, apoyarlo como tal. (Patrullero).

Parece que lo bonito que me ha dado la vida son los compañeros, lo bonito que me ha dado la policía son los compañeros, y no gracias a los superiores, estoy siendo claro, no gracias a los superiores sino gracias a los compañeros. Yo amo la policía. (Patrullero).

No patrulhamento observado, a dupla sempre está junta. Iniciam a jornada de trabalho, fazem as refeições e prestam conta de suas atividades sempre juntos. O desempenho do trabalho é mensurado em dupla, de acordo com os resultados alcançados no quadrante em que atuam. Sobre a questão da confiança, Bittner faz uma inferência importante:

\begin{abstract}
A despeito do fato de a lealdade fraternal da polícia não ser o que parece ao observador ingênuo (que considera 'os policiais como uma família grande e feliz') a verdade é que os policias tem de trabalhar com homens em que eles possam confiar. Isso acontece não porque isso ajuda a fazer com que seu desempenho pareça melhor do que realmente é (um policial está sempre pronto a atestar a excelência de seu companheiro), mas também em função dos inúmeros perigos e incertezas que são inerentes à ocupação." (BITTNER, 2003, p. 343).
\end{abstract}

No entanto, vale reforçar que esse modo de cooperação professional que avança em direção à dimensão afetiva não ocorre entre patrulleros e os seus superiores. Segundo eles, a relação com estes é "de trabalho".

[Com os superiores] Estrictamente laboral, estrictamente laboral, uno quisiera que hubiera un vínculo de pronto que profundice más en el superior que en uno, cierto, pero no lo hay, entonces lo laboral que es mi trabajo, y ya, cierto, 'señor tengo tal caso operativo' entonces lo que tenga que contarle se lo cuento, y listo, y no me involucro más. Con mis compañeros siempre se trata de construir personas, 'hermano no haga 
esto, vea sea consciente, busque estas maneras, venga yo le colaboro, venga miremos, venga busquemos maneras' los compañeros siempre son muy abiertos, y de pronto puede ser más normal porque uno siempre está con ellos, en cambio con los superiores uno los ve que pasan y ya, cierto. (Patrullero).

Con esos señores [superiores] uno habla muy poco porque ellos, no sé, ellos son más en el ámbito de solamente dar órdenes y ya. Si me entiende. Y a ellos no se les puede decir nada. Pero ellos no son personas groseras. Ellos son personas muy amables que también dan cosas muy buenas de qué hablar, ya que, obviamente, el comandante es el que más ejemplo tiene que dar. Todos vamos, todos seguimos al comandante. Pero, a veces los señores, si, a veces cuando se enojan, toca agachar la cabeza y hacer lo que ellos digan. No puede hacer uno nada. Toca quedarse callado. No lo van a echar a uno obviamente si se ponen de groseros, pero esa no es la idea de ser grosero. Porque uno no va ni a ganar nada ni a perder nada, pero uno de pronto si queda con esa mala actitud, con la referencia de que ¿ah, este policía por qué es así pues, es que nosotros qué le hicimos, si me entiende. Entonces, simplemente toca es cumplir y ya, a cabalidad lo que ordenen los jefes. (Patrullero).

Estrictamente de trabajo. Mientras que a veces con los mismos compañeros del mismo grado de uno hay un poquitico más de confianza. Uno a veces hace una, como decir, un convivencia como decir ¡ah, vamos muchachos, jugamos un partido! y solamente jugamos nosotros porque los señores oficiales o los comandantes, ellos no van. Solamente, estrictamente nosotros, si me entiende. (Patrullero)

Apesar de serem todos policiais, as relações de cumplicidade e parceria ocorrem entre os pares, ou seja, entre os que ocupam a mesma posição hierárquica na organização. Comparando-se as categorias da hierarquia da polícia colombiana e do Brasil, os patrulleros seriam considerados praças, e os seus comandantes oficiais. A literatura sobre polícia produzida no Brasil oferece um acervo significativo sobre o tema polícia ${ }^{52}$. Como base na produção acadêmica e em observação de campo, é possível inferir que praças e oficiais conformam duas polícias, com ingresso à corporação por diferentes portas, escola de formação distinta e matriz curricular também diferenciada, entre outras características. A despeito de, em seus labores concretizarem uma relação de interdependência e de complementaridade, esses dois 'mundos' apenas se tangenciam, fator que não facilita a criação de relações interpessoais em outros níveis além das necessidades de trabalho.

(..) lo que pasa es que... los comandantes en la policía... hay un déficit muy alto entre los jefes y los subalternos que somos nosotros... los oficiales... eso es una

\footnotetext{
${ }^{52}$ Sobre o tema polícia, ver Muniz, 1988; Poncioni, 2003; Nascimento, 2003; Suassuna, 2013; Silva, 2005; Maranhão, 2004.
} 
burguesía... ¿si sabe que es una burguesía? Los oficiales, es una burguesía. Ellos cuando se gradúan en la escuela en Bogotá, en la General Santander... el gobiernos les paga un pasaje en primera clase a los padres de familia, en avión... y un hotel cinco estrellas... a nosotros a veces no nos hacen ceremonia... nosotros somos los que ponemos el pecho haya arriba... en las escalas...algún día... de pronto el gobierno no nos agradece pero... allá arriba... el Dios de nosotros es el mismo de ellos. (Patrullero).

Por parte dos entrevistados da PMERJ, pontuou-se que, entre as praças e os oficiais, a relação se resume à "sim senhor, não senhor", ou seja, uma situação baseada em cumprimento de ordens, típica de regimes militares com uma linha de comando verticalizada e com baixa porosidade.

(...) E também tem comandante que deixa isso, deixa essa posição subir e esquece que aquilo ali é um ser humano, que saiu do Batalhão lá todo mundo igual. "Ah não mas lá fora eu ainda sou”, você é militar, mas você é humano, você é homem, homem forma geral, homem ou mulher tanto faz, você é um homem ser humano então, ele esquece isso, ele acha que ele é Deus. (Policial UPP).

Outro aspecto identificado foi a dificuldade de acesso direto aos superiores, pois para se ter contato com o comando da unidade, é preciso permissão de uma longa linha de intermediários, que assumem a função de 'filtrar' as demandas que chegam. Nas palavras de um entrevistado tentando me explicar, por meio de uma situação hipotética na qual eu seria o coronel: "Nós seriamos os peões e, no caso, a senhora seria o coronel, e para eu chegar, teria de falar com o sargento, com o tenente, para depois conversar com a senhora". Mesmo identificados esses entraves entre soldados e os seus superiores, ainda assim concordam que, no caso da UPP, a relação é mais próxima do que em uma unidade tradicional de polícia. Alguns fatores poderiam explicar essa diferenciação. Sendo o quantitativo de policiais menor nas UPP, os degraus hierárquicos também diminuem. Além disso, a proposta que recai sobre o projeto polícia pacificadora tem seu foco na burocracia interna reduzida, na perspectiva do policial mais 
próximo da comunidade e com mais autonomia. Sobre a UPP, já foram realizados alguns estudos e pesquisas ${ }^{53}$ que apontam dilemas, avanços e limitações. Esse, no entanto, não foi o tema da pesquisa realizada e, por isso, não será aprofundado.

O acesso dificultado ao comando interpõe barreiras de comunicação e bloqueios para um trabalho em equipe entre os que comandam e os que são comandados. Sem diálogo direto e permanente, os executores do trabalho de polícia nas ruas são afastados dos que tomam as decisões burocráticas e operacionais intramuros. Essa cisão impacta a ambas as funções, gerando uma percepção de inferioridade por parte das praças.

A relação com os colegas foi generalizadamente descrita como "tranquila", sem ênfase em nenhum aspecto em especial: "É legal porque vamos aprendendo uns com os outros, passando as experiências do dia a dia, crescendo juntos...” (Policial UPP).

\begin{abstract}
"Os pares no caso, ótima relação. Entendeu? Tem aquela situação de ser mais antigo, mais moderno, mas é só mesmo pra você ocupar alguma situação no cargo. Entendeu? Tipo na P2, tem eu, tem um mais antigo, são três cabos e dois soldados, um cabo mais antigo que trabalha na administração, que de certa forma ele administra, ajuda a administrar esta situação. Eu...tem um cara mais antigo que eu e os soldados. Então, a relação de nós três cabos é ótima. Não tem essa você é mais moderno, você é mais antigo... Não. É mesmo só pra ocupar cargo". (Policial UPP).
\end{abstract}

Em termos de diálogo com os superiores, os policiais colombianos usam a expressão “Qué ordena mi capitán, mi coronel...?” para se dirigir a eles. Essa forma de tratamento reflete o peso da hierarquia militar presente na polícia. Intrigante, no entanto, é que a PONAL se considera uma instituição civil, a qual, em comparação à PMERJ - oficialmente de natureza militar - no aspecto doutrina e cultura militar, a hierarquia e valores militares são igualmente valorizados e observados. Para a PONAL, essa questão pode revelar um conflito identitário, apresentado a partir da perspectiva da observação externa, dado que, em nenhuma entrevista ou espaço de observação, foi sinalizada tal problemática.

\footnotetext{
${ }^{53}$ Sobre UPP, ver Mourão, 2013; Soares, 2012; Fernandes, 2013.
} 
Importa evidenciar uma tendência verificada em ambas as instituições. Tanto na PMERJ quanto na PONAL, há iniciativas marcadamente de caráter comunitário, cuja meta é emprestar a prática policial um tom mais democratizado, em que o centro da atenção do trabalho de polícia está na cidadania, haja visto que o PVCC e a polícia de proximidade se sustentam nos pilares do policiamento comunitário. Não imperceptível está o fato de, em ambas as instituições, a questão da descentralização do comando não ser adotada no conjunto de práticas da filosofia norteadora da polícia comunitária (ou suas reinvenções nomeadas de outra forma). A descentralização do comando resulta em mais autonomia para os policiais da ponta, que exercem a tomada de decisão inevitavelmente (e não oficialmente reconhecida e autorizada). O poder de polícia materializado na tomada de decisão, na discricionariedade policial experimentada nas ruas não é abordado, de maneira contundente, nas polícias pesquisadas. $\mathrm{O}$ comando e a centralização da prerrogativa da decisão constituem-se em um núcleo duro para essas polícias.

Si doctora esos son decisiones que uno tiene que tomar, donde uno dice de pronto puede estar bien, de pronto puede estar mal, pero usted tiene que decidir lo que vaya a hacer y ya. Eso es cuando usted de pronto tiene que dar de baja a alguien, lo hago, no lo hago, porque está la vida suya, está la vida de él, de pronto un delincuente que le salga a uno por acá, no me ha tocado acá en la comuna gracias a Dios, porque hasta el momento yo digo que está muy calmado, hace tiempo, antes donde la comuna era tan llena de delincuencia, donde esto tomó tanta fama de ser tan malo, donde un delincuente de pronto de salga a usted con un arma de fuego, él no le va a apuntar solamente para ver si usted va a reaccionar, el instante que usted tiene que tomar es lo hace o no lo hace, porque está la vida primero suya, y la de él, y un delincuente primero se va él que cuidarlo a uno. Si son decisiones de vida o muerte. (Patrullero).

O trabalho dos policiais de ambas as polícias nas áreas onde estão alocados (UPP Santa Marta e Comuna 13) se desenvolve por meio de rondas, patrulhamento, abordagem a pessoas nas ruas ou motorizadas (Comuna13), revista pessoal e de documentos em caso de suspeita, e tarefas correlatas, segundo os grupos entrevistados. Em ambos os grupos, são realizadas atividades de aproximação à comunidade, como visitas a estabelecimentos e residências. Na 
programação policial, há atividades desportivas e lúdica/artísticas com jovens e crianças. Essas ações são investimentos para a mudança da cara da polícia, ou seja, atividades que assumem o propósito de apresentar à comunidade uma polícia mais humanizada e menos combatente, segundo os próprios interlocutores.

\subsection{ASPECTOS DA PRÁtica POLICIAL}

Na sociedade moderna, o objeto do trabalho de polícia é múltiplo, diverso e irrestrito. O trabalho de polícia se desenvolve de maneira generalizada, ou seja, em qualquer situação enfrentada, “ (...) a intervenção policial significa, acima de tudo, fazer uso da capacidade e da autoridade para superar a resistência a uma solução tentada no habitat [grifo do autor] nativo do problema" (BITTNER, p. 132, 2003).

O papel da polícia pode ser analisado com base em suas funções no cotidiano da execução de suas atividades. A polícia é uma instituição pública que possui como atribuição principal e genérica a preservação da paz e da ordem, em última análise, a garantia da vida em sociedade. Igualmente se encontra no centro da manutenção do poder do Estado, já que é assegurado à polícia o monopólio legítimo da força. Esse monopólio não é exclusivo, visto que outras profissões também gozam do uso legal e legítimo da força para assegurar obediência. Esse é o caso dos profissionais de saúde mental, dos agentes penitenciários e outros. A questão que distingue essas outras atividades profissionais da ação policial é que a polícia se configura como a única instituição autorizada ao uso irrestrito da força. Dito de outra forma, a polícia detém o monopólio da força sobre todos. Ao Estado cabe controlar e regular a violência privada por meio de sua força pública, que são as polícias. Por essa razão, a polícia é conhecida como o braço armado do Estado. Com bases nas especificidades do papel da instituição policial, pode- 
se conceber que a polícia está no locus da vida política, pois o controle social que exerce é “fundamentalmente uma questão política" (BAYLEY, p. 203-2006).

A relação da polícia com o Estado é de dependência. O regime de governo define o tom da ação de polícia em termos de sujeitos da intervenção, de objetivos, de meios e prioridades. Em governos democráticos, a polícia deve atuar e aplicar a força de maneira comedida, autorizada e legitimada pelo consentimento público. Em governos não democráticos, a polícia pode transformar-se em uma ameaça à população policiada, caso sua ação se dedique a garantir a tirania e a opressão de governantes.

Fazendo uma leitura da relação inversa, ou seja, dos impactos da ação de polícia ao governo, cabe ressaltar que a atuação da polícia interfere na capacidade de assegurar a governabilidade dos governos, como também sua legitimidade. Nesse sentido, a estabilidade e, por consequência a própria permanência do governo no poder, está suscetível ao impacto da ação de polícia. A atuação de polícia converte-se, então, em um indicador de democracia (ou tirania) do governo em questão. A polícia responde às prioridades estabelecidas pelo governo, o qual, por sua vez, estão inscritas em um complexo jogo de ideologias, conceitos, arranjos político-partidários, e uma permanente disputa entre interesses conflitantes.

Torna-se evidente que a definição da pauta policial, a construção de suas políticas de segurança e todos os processos internos, iniciados na seleção até a formação de seus profissionais, estarão diretamente suscetíveis aos desígnios do governo no qual a instituição policial se encontra inserida. A polícia, entendida como um instrumento de aplicação e distribuição de força, não poderá ser autônoma - e no cenário democrático moderno não o é por estar sempre subordinada à autoridade política.

Estado, polícia e sociedade estão intrinsicamente relacionados. A polícia, como representante do Estado nas ruas e do interesse público, por consequência, age sob a autorização e o consentimento social. Essa é a pedra de toque da democracia. Estando sob a aprovação e 
autorização da sociedade, a força pública do Estado não pode se autonomizar ou se emancipar da sociedade, assim como não se permite que o próprio Estado se emancipe da sociedade e imponha força opressiva e autoritária contra ela. Pela natureza e impacto de sua ação, a prerrogativa da força policial em um contexto democrático lhe impõe o uso comedido em intensidade, mas irrestrito em termos de objetos em que a ação incidirá. No entanto, Monjardet assinala que

\begin{abstract}
Não há polícia 'aperta-botão' que seu chefe (diretor de polícia, ministro, prefeito [maire] \{grifo no original\}, poder central) acionaria à vontade numa transparência total e com perfeita adequação entre intenção e resultado. Toda organização de trabalho comporta, pois, duas faces: um lado formal (estrutura, organogramas, recursos humanos e materiais, e seu arranjo segundo regras explícitas que determinam a maneira como a organização pode operar), e outro lado informal, que é o conjunto dos comportamento, e normas observáveis segundo as quais a organização realmente funciona (MONJARDET, 2003, p. 41).
\end{abstract}

O autor lança um alerta, pois a despeito de estar subordinada à autoridade política, a polícia (como uma organização) opera também segundo aspectos da cultura policial ${ }^{54}$ organizacional criada e estabelecida, que acrescenta à prática policial elementos de natureza informal, porém arraigados no ethos policial. Com isso, a polícia age segundo as normas institucionais, leis e diretrizes políticas na perspectiva oficial -empiricamente, o conjunto de elementos, de ordem subjetiva, que influencia a atuação policial forma um complexo cenário de caminhos e descaminhos em busca da dosagem mais acertada.

\title{
6.2. MANDATO DE POLÍCIA
}

Tratar o tema do mandato de polícia significa problematizar o próprio papel do Estado como garantidor de segurança pública, de paz e convivência social, isto é, de garantias mínimas

\footnotetext{
${ }^{54}$ Sobre cultura policial ver Kant de Lima (1989, 1994), Bretas (1997), Muniz (1999), Poncioni (2003).
} 
de manutenção da vida em sociedade. Não é um assunto de menor relevância, pois implica analisar como, onde e sobre quem o braço armado recairá, sob o império da lei e inscrito no consentimento social e legitimidade. É um tema intrínseco a regimes democráticos, pois, sem uma força policial, o Estado não poderia garantir a soberania da comunidade política e exercer a sua autoridade sobre um território definido, sob a tutela da própria sociedade. Alguns elementos como governabilidade, direitos humanos e vida democrática se tornam temas de fundo ao se problematizar o mandato policial.

Assim como o mandato policial é um assunto prioritário para a governabilidade democrática, esse é um tema primário para a tomada de decisão do policial nas ruas, no locus de sua ação, fundamentada em sua autoridade. O mandato policial responde às especificidades do trabalho policial, cuja natureza da ação é (i) diversa, (ii) imprevisível, (iii) imediata e (iiii) provisória. A natureza ( $i$ ) diversa da prática policial se estabelece justamente na diversidade de eventos que o cotidiano do policial no front da segurança pública lida. O infinito potencial é o limite da diversidade, nesse caso porque a criatividade humana, as ambições, os conflitos, as preferências e interesses são os ingredientes da massa do bolo que oferece os contornos do seu mandato. Em outras palavras, o policial nas ruas pode lidar com uma infinidade de eventos, que lhe demandarão uma infinidade de (re)ações, recursos, estratégias para produção de obediência, necessariamente circunscritos na legalidade e dosada pela legitimidade da ação. A justa medida, em síntese, torna-se o Eldorado para a polícia.

A (ii) imprevisibilidade da ação de polícia se consolida à medida que a realidade é dinâmica e que, em cada esquina ou cuadrante, o policial pode se deparar com uma ocorrência inesperada. Diante do inesperado, cabe reagir de maneira inédita. Evidentemente, tipos de situações podem repetir-se, e, assim, possibilitar ao policial colocar em prática respostas institucionalmente padronizadas e/ou legalmente circunscritas, porém, mais ou menos cumpridas, sem que isso signifique insubordinação ou ilegalidade. É inimaginável que, por 
exemplo, um mesmo tipo de crime, como um roubo de veículo, ocorra da mesma forma em momentos e cenários distintos. O ineditismo ou imprevisibilidade do evento não resulta em impossibilidade de se elaborar uma codificação proveniente da repetição de casos (ou em termos legais, tipificação penal) e, consequentemente, na adoção de um procedimento 'padrão'.

En la escuela uno puede ensenar lo teórico, lo escrito. La práctica hace el maestro. Cada procedimiento es algo nuevo para uno porque todos los días uno se va a encontrar con un nuevo procedimiento, algo distinto. (Patrullero)

Como te explico...me dió un barniz en la escuela, sé que ahí hay algo malo y yo tengo que proceder y aquí afuera aprendes bien cuál es el procedimiento que tienes que hacer, si me entiendes, en la escuela aprendes "si tengo que hacer algo, tengo que reaccionar, tengo que hacer algo" y ahí hay un procedimiento, pero en la escuela no se aprende muy bien a proceder. Le da a uno el conocimiento de policía estar uno capturando, llenando uno informes, aprendiendo conocimientos, y estar constantemente metido en el tema. (Patrullero)

[formação] Péssimo! Péssimo, a minha foi péssima, depois da minha ficou pior ainda. Na verdade foi 8 meses. Fiquei 8 meses lá. Mas de formação foram quatro. Hummm... 4 meses intenso, tendo instrução, 2 meses tendo instrução só de manhã, ou só à tarde, ou um dia, até completar 6 meses. Os outros 2 meses nós não fizemos nada, jogamos vídeo game o dia inteiro. (Policial UPP).

Na atuação policial, uma das características mais dramáticas se apresenta na necessidade de (iii) imediata resposta. Ao demandar a ação policial, a cidadania conta com a capacidade de sua pronta-resposta, porque a interrupção de um evento não desejado é urgente.

Em cada decisão policial, tem-se um tipo de conciliação prática, desafiadora do que seja o legal, o legítimo, o politicamente autorizado, o ético, o tecnicamente válido e o socialmente tolerado. Tudo isso se manifesta em cada ocorrência, a cada contexto, no tempo presente dos acontecimentos, na urgência daqueles que se veem, por algum motivo, expostos aos riscos e perigos, reais ou imaginados, da vida em sociedade. (MUNIZ \& SILVA, 2010, p. 457).

A autoridade policial se consolida na medida em que sua atuação possa garantir aos demandantes uma solução, mesmo que em essência (iiii) provisória. O fato de impedir ou interromper o cometimento de um crime, uma contravenção, um conflito evidencia o aspecto temporário da ação, já que essa intervenção não resulta em solução permanente para problemas complexos e multicausais. O policial, limitado pela natureza da sua ação, oferece a quem lhe 
demanda uma solução passageira, porém imprescindível para aquele espaço, tempo e situação. Sua autoridade ou poder são as prerrogativas socialmente autorizadas e legalmente definidas que asseguram a esses profissionais a capacidade de produzir obediência - e solução provisória, imediata - com o emprego de força potencial ou real. Nesse sentido, poder-se-ia afirmar que

Uma das características mais significativas do trabalho policial e simbólica de seu poder é a impossibilidade de resistência à sua intervenção, fato que confere ao policial a prerrogativa de 'law enforcers by force ${ }^{55}$, [grifo do original], expressão intencionalmente redundante, utilizada para chamar a atenção sobre o aspecto indelével do seu trabalho ser realizado por meio da imposição de sua autoridade instrumentalizada pela força. (ANJOS, 2010, p.23).

Os termos do mandato de polícia estão, em certa medida, contornados pelas especificidades de seu trabalho. Assumir a noção tradicional de mandato como uma autorização pública de uma comunidade política, a fim de que se autorize alguém ou a um grupo a realizar atividades acordadas pelas partes, em um território definido, ajuda a refletir sobre o mandato de polícia. Nesse sentido, a autorização outorgada implica responsabilidades e poder por parte do outorgado. Considerando-se a amplitude da ação policial, vale problematizar esse assunto. Os contornos do mandato policial são flexíveis, borrados pela dinamicidade social. Além de sua elasticidade, um aspecto relevante desse mandato reside no fato de o outorgante ser o objeto da ação do outorgado, ou seja, o mesmo grupo que autoriza a intervenção policial se conformará nos sujeitos sobre os quais incidirá a ação de polícia.

A bem da verdade, o exercício de se construir uma teoria para o mandato de uma atividade complexa como a de polícia, com as especificidades apresentadas, do ponto de vista conceitual, pode converter-se em um infrutífero esforço, se não se toma como ponto de partida

\footnotetext{
${ }^{55}$ Expressão cunhada pela autora.
} 
a prática desempenhada pelos profissionais de polícia. Nesse sentido, adverte e problematiza Bittner:

\begin{abstract}
A principal razão de as formulações do mandato policial não serem mais próximas das condições da prática real pela existência de regras mais detalhadas, mesmo quando tais regras detalhadas são elaboradas sob a égide, em princípio, da praticidade, é que todas as regras formais de conduta podem ser, fundamentalmente, revogadas (BITTNER, 2006, p. 96).
\end{abstract}

E, na verdade, são, já que a sociedade é soberana, e as leis estão a serviço da cidadania. A sociedade dispõe de poder de derrubar uma lei, alterá-la e ainda instituir novas. Isso em termos de leis gerais que regem uma sociedade democrática. Analogamente, da mesma forma, a polícia, ou melhor, a ação policial, mesmo sob a égide da lei e sob o controle dos padrões operacionais definidos para o exercício de suas atividades, é impactada pelo ineditismo e pela imprevisibilidade do evento. Esses são fatores determinantes para a resposta policial. Por essa razão, a lei, no caso, as normas de padronização operacional, podem e são revogadas, considerando-se que a dinâmica social é sempre cambiante.

Refletir amiúde sobre o mandato de polícia compõe o passo primordial para o avanço na compreensão do poder de polícia posto em ação, da autoridade policial nas ruas e da discricionariedade profissional no varejo da segurança pública. O mandato de polícia pode, assim, ser considerado como a moldura - mesmo com as margens borradas - da imagem que representa a prática policial. "De forma sucinta, é isso que define o mandato policial: o exercício do poder coercitivo autorizado pelo respaldo da força de forma legítima e legal" (MUNIZ \& PROENCA JUNIOR, 2007, p. 38).

A discricionariedade do policial que está na linha de frente da polícia, no dia a dia como "un disponible de la sociedad", é exercida cotidianamente. No entanto, essa discricionariedade se encontra inscrita no imediatismo do evento, em conformação com as circunstâncias que 
montam o cenário da ação. É possível identificar que o poder discricionário policial não é soberano ou rígido, pelo contrário, sofre ajustes finos diante de realidades distintas.

Isso significa dizer que a prática policial cede ao impacto ou à interferência da sociedade na qual a ação se inscreve. É de conhecimento público por meio de pesquisas e estudos (CARDOSO, 2014; MACHADO DA SILVA, 2010; COSTA, 2008; MACHADO DA SILVE \& LEITE, 2007; NASCIMENTO, 2003) que a resposta policial ao mesmo tipo de evento difere também de acordo com a localização territorial e social. Os policiais que estão alocados em unidades policiais onde a população local se encontra em condição social mais elevada, com mais conhecimento de seus direitos, exigindo da polícia (e do poder público em geral) a observância de seus direitos.

Esse cenário conforma um território no qual a ação de polícia deverá ser mais cautelosa, prudente e ajustada aos valores democráticos. Ao passo que, em áreas de estratos sociais de menor poder aquisitivo, em que a presença frágil e precária do Estado se configura no não exercício de direitos, a prática policial tende a ser mais arbitrária e violenta. A ação policial, portanto, se consolida por meio da resolução de uma equação complexa: território, contexto e natureza do evento, recursos e fins.

Com isso, pode ser refutada a concepção do trabalho policial como o simples cumprimento de leis, dado que não há uma fórmula para atuação de polícia. Pelo contrário, “como sabemos, o policial no seu dia a dia é forçado a tomar inúmeras decisões sobre quando e como sua autoridade poderá ser empregada" (PORTO \& COSTA, 2014, p. 77). O conteúdo da ação se desenha no próprio ato em curso, atendendo às escolhas do profissional. A decisão final sobre o caminho a ser seguido diante de um evento cabe ao policial, cuja discricionariedade lhe outorga tanto o dever da ação como a responsabilidade derivada das consequências. Essa não é uma tarefa simples. A autoridade policial em ação mobiliza recursos, 
técnicas e táticas que devem ser disponibilizadas de imediato, de maneira comedida no uso da força e em sintonia com a situação em particular.

Um debate cabível a esse momento seria sobre a demanda que chega às instituições policiais na sociedade moderna. As polícias são evocadas para lidar (e solucionar) com uma sorte infinita de problemas sociais. Esse fenômeno se apoia na multiplicidade e complexidade das relações e interações sociais em grandes populações, ainda crescentes.

Analogamente, em grupos menores, como os núcleos familiares, a autoridade familiar constituída se encarrega de manter a ordem. Quando se observa a relação entre grupos sociais, com distintos interesses, cosmovisão e cultura, a possibilidade de conflitos administráveis intra e intercomunidades se amplia. A autoridade familiar que mantinha o controle sobre seu pequeno grupo não exerce essa função quando as relações crescem em número e alcançam um grau de complexidade elevado.

Nesse sentido, a constituição de um corpo externo e profissional parece ser a forma mais exequível de preservação da ordem e resolução de problemas. A polícia incorpora, na sociedade moderna, o papel de profissionalmente manter a ordem e evitar conflitos. Sendo a polícia a porção mais tangível do Estado, em última análise o Estado, via instituições policiais, se responsabiliza por essa função. Essa reflexão da função da polícia na sociedade moderna pode ser considerada como a hipótese que sustenta a demanda crescente pela atenção e intervenção policial para tudo. A concepção da demanda crescente e irrestrita do trabalho de polícia, é proposta por Bayley nos seus esforços para a formulação de uma teoria de polícia.

Especificamente, a necessidade de serviços de polícia surgirá em comunidades que não matem a disciplina social e a ordem através dos processos sociais informais. (...) As pessoas são obrigadas a se voltar para instituições formais a fim de resolver conflitos que antes eram solucionados por grupos informais. $\mathrm{Na}$ maior parte do mundo, o locus [grifo no original] primário para essas instituições é o Estado. (BAYLEY, 2006, p.146). 
Pelo que foi discutido até agora, pode-se notar que o mandato policial está aberto (MUNIZ \& PROENCA JUNIOR, 2007). Entre as alternativas de disponíveis para um sem número de eventos, a escolha pela ação mais adequada deve estar assentada em alguns parâmetros balizadores da prática policial. E por isso, o mandato não está totalmente aberto quando se faz o exercício de aterrissá-lo nas polícias estudadas, observando os procedimentos adotados pelos profissionais nas ruas. Para Muniz, o conhecimento e aprovação dos procedimentos policiais por uma sociedade constituem ponto decisivo para o tratamento democrático da ação policial, que enfatiza que:

Os procedimentos policiais nada mais são do que a versão operacional dos poderes concedidos e consentidos pela sociedade às polícias e ao governo para a sustentação da lei e da ordem pactuada. (MUNIZ, 2014, p. 4).

Na PMERJ, os policiais têm como referência os POPs (Procedimentos Operacionais Padrão), que são recomendações extraídas de sua própria experiência empírica. Nesse caso, a empiria se converte em recomendação instrumental institucional. Como o fazer polícia é uma tarefa dinâmica e repleta de possibilidades de (re)ação, os POPs sofrem alterações e ajustes ao longo do tempo, e ainda podem ser excluídos à medida que o procedimento não seja considerado adequado à realidade atual. Esse é um exercício de permanente adaptação ao universo mutante da prática policial. De fato, a busca pelo procedimento adequado pode ser considerada como o elemento propulsor dos ajustes realizados, naquilo que é tido como padrão. Portanto, padrão é uma categoria temporal e relacional diretamente influenciada pelas idiossincrasias da comunidade e mudanças nos objetivos da ação de polícia.

Os policiais colombianos, da mesma forma, possuem um conjunto de procedimentos operacionais padronizados disponíveis para apoiar a ação de polícia, e a definição do procedimento a ser adotado. Esses procedimentos e outras informações referentes à ação de polícia estão organizados em uma plataforma virtual chamada Suite Vision Empresarial. Nessa 
plataforma estão disponibilizados conteúdos diversos relativos à ação de polícia, como leis, diretrizes operacionais, políticas desenvolvidas pela polícia e pelo governo, planos e outros temas referentes às demais atribuições da polícia colombiana (polícia judiciária, atividades especializadas, inteligência, investigação, etc).

Cada equipe de patrullaje conta com um dispositivo eletrônico chamado PDA ${ }^{56}$ (Personal Digital Assistant). Nas ruas, eles podem ter acesso ao conteúdo completo da plataforma e fazer consultas sobre procedimentos operacionais e sobre registro de pessoas e de veículos. Essas são, portanto, tentativas para emprestar algum contorno ao amplo escopo do mandato policial. São esforços de traduzir a prática policial em recomendações que também revelam o que é prioritário, legítimo e 'politicamente correto' para uma sociedade em dado momento histórico. A padronização de procedimentos operacionais, assim, é transversalizada pela temporalidade e territorialidade da ação ou do procedimento. Nesse sentido, ela também pode ser concebida como uma escolha entre um leque de alternativas, cuja meta é oficializar o modus operandi policial elaborado e experimentado nas ruas.

\subsection{O QUE OS POLICIAIS DIZEM SOBRE O PROCESSO DECISÓRIO NAS RUAS}

[Police] Officers decisions are very consequential in the lives of citizens and in the quality of life of neighborhoods and communities. The initial decision to stop and arrest sets in motion fateful mechanisms producing stress, economic loss, and possible punishment. The decision is binary: intervene or not, arrest or not, ticket or not, etc. Furthermore, police decision making is more complex than other legal decisionmaking. The less serious the offense, the wider the choice of actions. The conduct subject to policing control varies widely from highly trivial untoward behavior to crimes of the utmost gravity. (MANING, 2003, p. 179).

\footnotetext{
${ }^{56}$ A PDA é dispositivo eletrônico - semelhante a um palmtop - que serve para acessar a base virtual Suite Vision Empresarial, criada para o serviço público colombiano. O acesso ocorre por meio de senha própria do funcionário. Para o trabalho policial, além do acesso aos procedimentos policiais, este dispositivo serve também para consultas aos sistemas nacionais de registro de pessoas e de veículos. O policial nas ruas pode verificar a documentação da pessoa e ter acesso ao seu histórico criminal. No caso de veículos, eles podem ter conhecimento do histórico do veículo em termos de sua legalização e condição atual.
} 
O exercício decisório exige dos policiais - no ato da tomada de decisão e no calor do acontecimento - a capacidade de, em segundos, classificar o evento em criminal ou não criminal, definir o grau de violência da situação, calcular uma resposta policial e profissional conformada pela lei e legítima diante dos fatos e envolvidos. E, somado a isso, o grau de risco de morte que o caso apresenta aos policiais, e aos demais. Isso implica (re)agir instantaneamente, ponderando e aplicando o resultado da complexa análise realizada.

A coercitividade em justa medida aplicada discricionariamente ao evento em andamento é o produto final da obra. Mesmo assim, esse produto final, por vezes, carece de justificação pública e institucional porque os fantasmas de um possível escândalo veiculado pela mídia e da punição perseguem as decisões dos policiais. Como se trata de duas polícias militarizadas, a disciplina é um tema intrínseco aos princípios organizacionais, fato que explica a preocupação com a punição nos parâmetros da doutrina militar. E, ainda pior, segundo os entrevistados, seria uma possível responsabilização penal - o que também assombra a prática policial.

\footnotetext{
Uno aquí para proceder no necesita de tiempo, necesita de un instante nada más para proceder: hago esto o no lago. Tiene que decidir de una vez. Lo hago o no lo hago, ya. Son decisiones que uno tiene que tomar donde uno dice, de pronto, puede estar bien, de pronto, puede estar mal. (Patrullero).
}

Considerando-se que o quantitativo e a natureza dos casos que um plantão policial pode receber é imprevisível, a decisão binária (MANING, 2003) de prender ou não, de revistar ou não, de atirar ou não, é posterior à definição da gravidade do evento. Os policiais colombianos entrevistados relataram que a maior parte de seu tempo de trabalho é gasta com atendimentos não criminais, seguidos de criminais de baixo potencial ofensivo como agressão, violências intrafamiliar e de gênero. "La gente llama a uno para cualquier situación. (...) Las personas creen que, uno como policía, tiene como la magia, de pronto, para arreglar todo" (Patrullero). As chamadas para ocorrências não criminais são, e não são, trabalho de polícia, para eles. 
Na PONAL, essas demandas comunitárias não criminais são incorporadas e assumidas pela polícia como uma responsabilidade institucional junto à comunidade de "colaborarles con lo que sea”. Os policiais, nas ruas, representam a alternativa mais disponível e efetiva para resolução de problemas comunitários. Eles estão acessíveis nos territórios em que a demanda se apresenta, sendo qualificados para "arreglar las cosas" por intermédio dos meios adequados à situação e, assim, autorizados para impor obediência. E, por isso, esclarecem que o trabalho "não policial" é incorporado às suas responsabilidades, mesmo que não seja de natureza policial.

\begin{abstract}
[Casos que nao de policía] Sí, claro... como por ejemplo, usted por qué me tiene que llamar a mí para decirme... que la vecina se le está meando... que el perro se le está meando en su anden... haciendo sus necesidades. Eso es algo de cultura, eso es algo que alguien tiene que ir a regañar a otro. Es frecuente. Otro ejemplo que... me llamen a decirle a alguien que le baje el volumen a la música... no me parece. (Patrullero).
\end{abstract}

Un requerimiento de la ciudadanía... como por ejemplo ayer... una señora me llamó a decirme que había encontrado un pajarito... yo como vigilancia... no es mi función... la función es de policía ambiental... otra especialidad. ¿Por qué la central me mandó a mí?... porque es mi cuadrante, es mi sector, y tengo que responder... pero yo, siendo jefe... que llamen a la central a decir lo del pajarito... yo marco y llamo directamente a ambiental... y así la patrulla no pierde tiempo viendo por un pajarito. Era un ave que estaba herida y la querían entregar a ambiental... eso era. (Patrullero).

Tem muita assistência social, pra essa UPP aqui é muita assistência social, O policiamento hoje em dia, a maioria das ocorrências, digo $70 \%$ também é assistência social, briga entre familiar, marido e mulher, filhos, vizinhos. (Policial UPP).

É, mas tem assistência social que é só abaixar o som alto, não é coisa de policial, mas é que a gente faz essa função policial hoje em dia, tem muita ocorrência que não é policial, a gente acaba pegando... É, coisas que às vezes não é do policial. É porque a gente está próximo do morador, e só tem o policial pra buscar ajuda, é o socorro mais próximo ali. (Policial UPP).

Importa sinalizar que a estratégia policial colombiana de resolução de conflitos passa primeiramente pela evocação de valores cívicos inerentes à política de convivência pacífica e cidadã, secundariamente (e se essa primeira estratégia falhar), lança-se mão da evocação da lei como estratégia de persuasão e dissolução de conflitos. O enfoque de policiamento comunitário com ênfase na resolução pacífica do conflito é a tônica do patrulhamento colombiano. Nesse 
sentido, faz-se relevante considerar, para efeito de análise, os pilares do policiamento comunitário, os quais, para Skolnick \& Bayley, são:

1.Organizar a prevenção do crime tendo como base a comunidade; 2.Reorientar as atividades de policiamento para enfatizar os serviços não-emergenciais; 3.Aumentar a responsabilização da polícia; 4.Descentralizar o comando. (SKOLNICK \& BAYLEY, 2006, p.19).

De modo geral, a perspectiva da prevenção comunitária da criminalidade é o ponto central para o policiamento comunitário por envolver a população em um esquema ampliado de vigilância e proteção, desempenhado pelos seus membros que, dessa forma, incrementam as chances de não vitimização local. Por reorientação do policiamento, estimula-se o envolvimento dos policiais com a comunidade, suscitando maior interação para que as equipes de policiamento tenham mais conhecimento sobre as dinâmicas sociais dos territórios policiados. Em síntese, seria priorizar as atividades que aproximem o policial da comunidade, e que o façam mais presente e acessível para encorajar a comunidade a interagir e demandar ações não emergenciais. Para alcançar proximidade, a ideia é retirar o policial do policiamento motorizado e distanciado, para mantê-lo em um posto fixo, em pontos diversos da comunidade.

A questão da maior responsabilização da polícia se refere a criar espaços e canais de diálogo entre os policiais e os membros da comunidade. Na prática, isso significa dar à comunidade espaço para criticar e inquerir sobre práticas policiais e quaisquer outras temáticas que se apresentem. É bem verdade que, quando se concretiza um canal efetivo de diálogo entre duas partes, todos os tipos de leituras e verdades parciais podem ser comunicados. Esse é um desafio, o qual, caso implementado pelas polícias, lhes permitirá ter contato direto com a percepção que a sociedade tem da instituição e da prática policial.

Com relação à descentralização do comando, para instituições policiais militarizadas, é um tema abordado com cautela, pois se trata de tocar nos principais valores da doutrina militar: disciplina e hierarquia. A descentralização do comando implica que os policiais de baixo grau 
hierárquico gozariam de autonomia para alterar estratégias e prioridades, à medida que a dinâmica de seu território o exija. Empiricamente, seria assegurar oficialmente ao policial maior autonomia decisória. Oficialmente, aplica-se para enfatizar que, no dia a dia das ruas, ele não deixou de decidir o que deveria fazer.

Vale mencionar que, neste trabalho, não se abordará com profundidade o tema do policiamento comunitário $^{57}$. Portanto, aqui não se empreendederá uma análise sobre sua implementação nos países pesquisados. No entanto, para fins de contextualização sobre o modus operandi das instituições policiais pesquisadas, cabe tratar suas principais características. Esse exercício, principalmente, serve para oferecer alguns elementos importantes sobre a prática policial colombiana, que se apropriou dessa filosofia em sua política de patrullaje.

Em sua rotina de policiamento nas ruas, o policial assume funções de polícia comunitária, utilizando estratégias de aproximação da comunidade por meio do desenvolvimento de atividades desportivas, lúdicas, distribuição de material educativo e preventivo contra crimes, visitas domiciliares para fins de cadastramento de famílias, dentre outras medidas, cujas finalidades são estar mais presente e acessível à comunidade, bem como adquirir maior conhecimento sobre a dinâmica social local. E, além disso, a perspectiva norteadora de sua prática demanda uma postura mais comunitária e menos interventiva, ou seja, o policial se apresenta como um profissional à disposição da comunidade para, com base na negociação e no diálogo, oferecer uma solução à problemática encontrada.

Bueno, acá en Colombia, dentro de las ciudades, la policía del área metropolitana, la policía trabaja algo que se llama puerta a puerta, entonces consiste en que va golpeando, regalas el número del cuadrante, te presentas como la patrulla, que la gente te conozca, conocer las personas, hablar con ellas, entonces con el tiempo uno aprende a conocer las personas dentro de su sector. Entonces como se da cuenta, la policía acá e Colombia trabaja por... es un modelo de vigilancia comunitaria por cuadrantes.

\footnotetext{
${ }^{57}$ Sobre policiamento comunitário ver: Batista (2001), Holanda (2005), Trajanowicz (1972), Muniz, Larvie, Musumeci \& Freire (1997), Skolnick \& Bayley (2006), Ribeiro (2014).
} 
Digámoslo ya... uno conoce las personas... las personas que viven en su cuadrante quiénes son. Entonces, eso es lo que pasa, cada seis meses pasa uno volviendo, recogiendo, de pronto, porque como hay personas que se van y hay personas que llegan nuevas, entonces pasa uno con una planilla regalando nuevamente el cuadrante, pidiendo cuántas personas viven, quienes viven, cuántos mayores, cuántos menores, entonces, en eso consiste. Con eso, uno aprende a conocer las personas. (Patrullero).

No entanto, à parte das atividades de polícia comunitária que inspira a patrullaje, na Colômbia a questão da descentralização do comando se mantém fora dos investimentos em polícia comunitária. No trabalho de campo, notou-se que as questões centrais da doutrina militar estão preservadas. Hierarquia e disciplina são elementos presentes e intocáveis, pelo menos nesse momento. Essa é a temática que não entra na pauta do dia na instituição policial. O comando centralizado ainda é compreendido como necessário para o cumprimento da missão policial, já que garante que, em todos os graus hierárquicos, o que é determinado deve ser cumprido. A máxima missão dada é missão cumprida sintetiza o debate sobre a relevância da doutrina militar.

Ao se comparar as prioridades do policiamento comunitário com o policiamento tradicional, atesta-se que a perspectiva comunitária tem como princípio a resolução do problema com o foco nas pessoas envolvidas, enquanto a perspectiva tradicional de policiamento busca uma solução para a problemática, mantendo o foco no problema. Um exemplo talvez seja mais didático para esclarecer essa questão. Hipotética e didaticamente, tomemos uma briga de vizinhos para comparar as duas concepções de policiamento.

No policiamento comunitário, com ênfase na resolução pacífica de conflitos, o policial tentará solucionar o conflito que gerou a briga, para alcançar um acordo entre as partes conflitantes. O mesmo caso levado ao policial, que responde aos conceitos do policiamento tradicional, levaria-o a enquadrar o caso no código penal, devido à ocorrência de agressão, procedendo como define o protocolo nesses casos. A distinção entre ambas as concepções é a orientação sobre o foco de atenção e atuação. Vale pontuar, assim, que a prática policial é um 
projeto em construção, no sentido de que muitos são os condicionantes que a conformam. Ressalte-se que, além disso, tais condicionamentos são efêmeros.

A construção da prática policial, perpassada pelos princípios da polícia comunitária, decerto depõe contra a concepção do policial como agente de law enforcement, que tem como função a garantia do cumprimento da lei inserida na noção do trabalho policial dedicado à criminalidade, ao combate ao crime. Essa percepção dista do trabalho assumidamente realizado por esses policiais de resolução de conflitos interpessoais e comunitários, de manutenção da ordem e de muitas outras atividades que correspondem a um sem fim de assuntos que surgem no seu cotidiano, que não envolvem a aplicação da lei.

A despeito dos relatos policiais apresentarem uma percepção dicotômica sobre a natureza das demandas que chegam à polícia, isso não pareceu ser um dilema para eles. $\mathrm{Na}$ PONAL, reforça-se, em vários âmbitos, a filosofia institucional de resolução de conflitos, desde a formação até as preleções cotidianas em cada início de turno. Assim, a massificação desse perfil de atuação policial resulta em maior aceitação do papel que a instituição espera que o policial assuma na sua prática.

\footnotetext{
Básicamente cuando una persona hace un llamado, de pronto, a las autoridades es porque entre ellos no los pueden solucionar. Nosotros estamos es para, independientemente de lo que sea, ayudar a la ciudadanía. (...) La verdad considero que si una persona llama a la policía es porque no tiene la orientación o la capacidad suficiente para resolver su problema. (Patrullero).
}

Entre os procedimentos operacionais padronizados para a atividade de patrullaje adotados pela PONAL, um deles seria iniciar a abordagem por meio do diálogo, acalmando, assim, as partes, caso essa medida seja aplicável à situação. O patrulhamento tem como recomendação e máxima o SEA, ou seja, a sigla para "saludar, escuchar, actúar". A perspectiva da resolução de conflitos juntamente com o padrão operacional SEA imprime à ação de polícia um caráter explicitamente mais comunitário que combatente. A meta do policial colombiano 
diante de ocorrências é buscar resolver pacificamente, e no local, o caso, segundo eles. Faz-se importante lembrar que os entrevistados lidavam com casos de baixo grau de violência, na maior parte das situações. Evidentemente, isso lhes possibilitava empregar ferramentas baseadas na negociação, e de maneira dialógica.

[Para reducirlo ${ }^{58}$ ] Primero nosotros utilizamos el dialogo. Si vemos que no podemos con el dialogo y la persona está demasiado alterada, está demasiado agresivo, ahí sí nos toca colocar las esposas. (Patrullero).

Nas entrevistas, quando indagados sobre os recursos e ferramentas que se apropriam no momento de decidir o que fazer com o caso, alguns policiais indicaram a formação como a fonte do modo escolhido para actúar. Dito de outra forma, as habilidades pessoais forjadas pelos conhecimentos absorvidos na formação são preponderantes no momento da escolha da ação a ser empregada. Essa concepção do processo decisório não corresponde à totalidade, pois, para outros, a formação ofereceu uma primeira abordagem superficial e teórica do trabalho de polícia. Para esses, a experiência empírica das ruas cumpria o papel de guia de ação e base de decisão. De fato, para esse grupo, as ruas foram e continuam sendo a melhor formação e escola.

\footnotetext{
Esos son conocimientos complementarios [os conhecimentos da formacão]. Aprendo en la escuela que si hay algo malo tengo que proceder, y aquí afuera aprendo viviendo cual es el proceso que se va a hacer. (Patrullero).

En el curso de formación nos dan como un barniz, algo por encima. Pero el verdadero policía se forma en la calle" (Patrullero).

Ya eso [a decisão], para mí, sí es como la experiencia que tengo en la policía. (Patrullero).

Lo que me enseñan en la escuela es ser un ciudadano ejemplar. En términos de procedimientos, es hacer lo legal. (Patrullero).

Todos los procedimientos de nosotros como policía están escritos, absolutamente todos. Inclusive tenemos una plataforma que se llama suite vision empresarial en donde todos están estandarizado. Pero eso [a decisão] no. Porque? Porque eso se llama, más que todo, es la malicia de uno, la experiencia en mirar el terreno, en mirar como es mi cuadrante, como es la aceptación del ciudadano de ese sector hacia mi. (Patrullero).
}

\footnotetext{
58 "Reducir" a uma pessoa significa empregar técnicas de controle ou imobilização na pessoa, de maneira a mantê-la sob controle, que obedecem a uma escala de intensidade. Primeiramente, o diálogo, e a depender do estado da pessoa, pode-se chegar a algemá-la ("colocar las esposas"), se assim for necessário.
} 
Yo digo alrededor del $75 \%$ casi $80 \%$ viene de la calle, además tu sabes que el instinto para detectar situaciones raras, anómalas, se aprende en la calle. Yo voy y registro y este man esta como sospechoso, este man esta como dando muchas vueltas, voy y lo registro y encuentro un arma de fuego, bueno listo, cierto. $\mathrm{O}$ a las 3 de la mañana veo a un man con una cajita, un man con cara de vicioso con una cajita va por la calle, ese man lo más normal es que lleve productos robados, no estoy juzgando, porque no se trata de eso, pero es común que se den este tipo de situaciones, y cosas que obviamente uno no haría, y que un policía en la calle empieza a sacar información para que las personas lo digan, "ah es verdad mi agente tienen toda la razón", después de uno decirle, insistirle, buscar maneras de interrogar, hablarle, "ah esto es robado mi agente tiene razón" son aptitudes que se aprenden en la calle, a detectar situaciones y cosas que la escuela no se la enseñan a uno, se vuelve muy instintivo, es casi como una cacería, y a usted en la escuela no le enseñan eso. (Patrullero).

Não houve consenso sobre o que sustenta a tomada de decisão no calor do evento. No entanto, é possível destacar, pela maioria dos entrevistados, que a experiência nas ruas foi apontada como a fonte do processo decisório. Para uma profissão cuja prática, segundo as entrevistas, se faz decisiva nos momentos em que uma situação se apresenta nas ruas, há de se considerar o saber policial como central para o processo decisório. Com o avançar da conversa, e a criação de novas formas de perguntar sobre o mesmo assunto, eles ressaltaram que, além da experiência própria, a vivência do "compañero" mais antigo também pode ser considerada um fator de impacto nesse processo.

\begin{abstract}
Exactamente, yo tuve un compañero que llevaba 10 años en la policía, él me ha enseñado bastante, me ha asesorado bastante, la policía siempre se ha enfocado mucho en un hombre nuevo ponerlo con uno antiguo, que tenga conocimiento, que tenga experiencia, pero a veces no hay gente, entonces le toca a dos nuevos, que se vayan, porque es que a la hora de la verdad tienen que cubrir, entonces normalmente muchas veces la policía se preocupa porque haya un hombre en la calle, pero no se preocupa por ver que conocimiento tiene, que asesoría tiene, que acompañamiento tienen, aunque pues también la policía, como te lo había dicho, en la calle somos más hermanos entre compañeros, entonces "hey, jefe, vea, mira que no tengo conocimiento en esto colabóreme" "ah muchachos eso se hace de tal manera... (Patrullero).
\end{abstract}

Um aspecto importante que vale destacar é o de que, generalizadamente, aos policiais lhes custou muito para identificar a origem ou a motivação para a decisão que tomam. Eles indicaram que, apesar de sair da escola de formação com uma base de conhecimento 
aprimorado "en las calles", as respostas se concentraram em "es lo que toca hacer", ou seja, o que tem de ser feito. A maior parte dos entrevistados, quando indagados sobre esse assunto, esticavam os olhos ao infinito para encontrar uma resposta. Essa questão provocava um movimento de análise, que parecia inédito. A questão do processo decisório na ação de polícia, para esse grupo, não se configurou em um exercício simples. E bem provavelmente não o seja, pois as especificidades da ação de polícia parecem ser evidências do grau de complexidade das decisões que tomam no curso dos casos que atendem.

Por outro lado, houve narrativas ainda distintas das anteriores. Para alguns dos entrevistados, nem a formação nem a experiência nas ruas foram consideradas como as bases para a tomada de decisão. Pelo contrário, em seus relatos e análises indicaram - com um tom de confidência - que, efetivamente, o que lhes impulsionou a agir de uma determinada maneira ou de outra foi um tipo de intuição ou "instinto".

\begin{abstract}
No, no. En este momento esa fue la reacción mía. En esos momentos no sé, fue la reacción mía. Pues, es malo de pronto decir que fue miedo porque miedo nos sentimos todos. (...) Fue como un instinto mío de salvaguardar tanto la vida mía como la del compañero. (Patrullero).

Yo digo alrededor del $75 \%$ casi $80 \%$ viene de la calle, además tu sabes que el instinto para detectar situaciones raras, anómalas, se aprende en la calle. Yo voy y registro y este man esta como sospechoso, este man esta como dando muchas vueltas, voy y lo registro y encuentro un arma de fuego, bueno listo, cierto. $\mathrm{O}$ a las 3 de la mañana veo a un man con una cajita, un man con cara de vicioso con una cajita va por la calle, ese man lo más normal es que lleve productos robados, no estoy juzgando, porque no se trata de eso, pero es común que se den este tipo de situaciones, y cosas que obviamente uno no haría, y que un policía en la calle empieza a sacar información para que las personas lo digan, 'ah es verdad mi agente tienen toda la razón', después de uno decirle, insistirle, buscar maneras de interrogar, hablarle, 'ah esto es robado mi agente tiene razón' son aptitudes que se aprenden en la calle, a detectar situaciones y cosas que la escuela no se la enseñan a uno, se vuelve muy instintivo, es casi como una cacería, y a usted en la escuela no le enseñan eso. (Patrullero).
\end{abstract}

O primeiro relato chama a atenção para o que poderia ser entendido como uma esquizofrenia operacional. Contudo, esse depoimento conta que a decisão policial diante de um evento é impactada pela sua gravidade. O grau de violência e letalidade do caso tem um papel decisivo na percepção dos entrevistados sobre a sua decisão. Os casos nos quais enfrentavam 
risco de morte são justamente os que não lhes foi possível identificar a origem da reação, da resposta policial. Parece que, ao lidar com esse tipo de situação, o modus operandi policial entra em uma frequência modular indecifrável. Os recursos que põem em prática nos momentos decisivos em ocorrências com grau elevado de potencial ofensivo não perpassa pela racionalidade, segundo eles. Não é um processo cognitivamente desenhado e empregado. A ação, via de regra, imediata e urgente, não permite avaliações anteriores. Ao passo que, em casos de baixo potencial ofensivo, foi possível reconhecer - mesmo com dificuldade - o procedimento adotado e a sua base originária.

O segundo relato aborda a característica mais citada quando perguntados acerca da base para a tomada de decisão: instinto. Por instinto, as narrativas revelam que é algo que não se aprende, uma reação instantânea e de origem inalcançável, em termos cognitivos. Em outras palavras, algo que os entrevistados não sabem explicar, apenas sentem e agem, em função de suas sensações. Por um lado, é compreensível que tal prerrogativa seja lançada para explicar (ou tentar) as inumeráveis reações a diversas situações que enfrentam nas suas atividades de trabalho. Encontrar a justificativa para cada ação, a qual, aparentemente, parece ser natural, não é um exercício ao qual são submetidos.

Por outro lado, ao fim do segundo relato, o entrevistado deixa uma pista para essa questão. O tema da aprendizagem adquirida nas ruas (leia-se, a experiência de trabalho empírico), com as situações que lidam, assegura-lhe uma janela para o entendimento sobre os elementos ou insumos ou recursos que tem de lançar mão no momento de uma tomada de decisão. De qualquer maneira, o fato intrigante é que, para os policiais, a experiência não aparece como um fator ou componente preponderante ao instinto. Apesar de a apontarem como muito importante para o exercício de suas funções, alçam outra justificativa, a qual, por sua vez, arremete-lhes a um campo fora do alcance da cognição. 
Nas entrevistas, quando solicitados a narrar alguns casos, foi interessante notar a dificuldade para contar determinado episódio. A justificativa para essa questão foi apontada como sendo a escassez de ocorrências (policiais) na Comuna 13. Boa parte dos entrevistados narraram situações ocorridas fora da comuna por considerarem os episódios vividos em outras áreas como casos “más relevantes". Essa é outra questão-chave para o processo decisório. O grau de relevância de uma ocorrência está em relação direta com a gravidade da situação, de acordo com a percepção dos casos narrados.

Sobre isso, pode haver dois pontos a destacar. Primeiramente, os policiais não classificam os casos que mais atendem - aqueles que envolvem baixo grau de violência - como "riñas de vecinos", violência doméstica, etc., a exemplo das ocorrências não criminais - os que envolvem polícia, apesar de considerarem como os mais indicados para atender a esses tipos de solicitação. Em decorrência de suas experiências, os "patrulleros" concordam que os casos que não consideram ser de polícia, e que a população lhes demanda intervir, devem-se ao fato de que os envolvidos não têm condições de resolver por eles mesmos a situação. Diante da incapacidade de resolução dos seus conflitos, a polícia passa a ser o recurso disponível mais efetivo, já que a intervenção policial faz com que a população se sinta mais segura.

Los casos más frecuentes son, por ejemplo, son bulla, de pronto, por exceso de volumen en los equipos en los fines de semana. (...) esos son los casos que atiendo en mi cuadrante. O sea, son pequeñas cosas, no son cosas, de pronto, de relevancia. (Patrullero).

O segundo ponto, derivado do primeiro, pode ser explicado pelo fato de que, por não classificar o cotidiano do trabalho que realizam como relevante, subvalorizam seu próprio labor e mascaram a realidade enfrentada nas ruas. Os entrevistados explicitaram uma incoerência, pois assumem as situações de baixo potencial ofensivo e não criminais, mas não consideram ser esse um trabalho de polícia. Há uma inaceitação velada, que escapa nos momentos de narrar 
os casos de polícia de verdade. Os policiais operacionalizam a sua prática profissional mediante um conflito interno que se resume em: eu não deveria fazer isso, mas sou o único disponível e qualificado para fazê-lo; mesmo assim, não considero que isso seja meu trabalho de fato.

Esse conflito se desdobra no que diz respeito ao registro dos casos atendidos. Como rotina de trabalho, os policiais devem registar as ocorrências de seu plantão em um livro - Libro de Población - guardado no CAI que corresponde ao quadrante policiado. Segundo seus relatos, no livro somente se registra "lo que es más relevante" para eles, ou seja, a discricionariedade policial igualmente define o que deve ou não ser registrado e, consequentemente, o que pode ser classificado como caso de polícia. O registro então ocorre excluindo o grosso do trabalho que realizam: os atendimentos às diversas demandas dos cidadãos que recorrem à polícia como uma alternativa para a resolução de seus conflitos cotidianos. E, no caso colombiano, os próprios policiais se consideram indicados para atender a essas demandas. Esses são filtros perversos porque se voltam contra a própria polícia. Na linguagem policial, "um tiro no pé”. Aqui se apresentam questões que expõem problemas estruturais em torno do trabalho de polícia, ou em uma perspectiva mais ampla, a própria função da polícia.

Também se observa que a discricionariedade policial se interpõe, portanto, na produção da verdade, na socialização intra e extra institucional do contexto real experimentado nas ruas. Há, nesse aspecto, um conflito no tratamento dado ao material com o qual o policial trabalha: os casos. Por um lado, a instituição forma o policial e demanda da parte dele que esteja disponível aos cidadãos para todas as situações comunitárias e individuais. Por outro, mesmo atendendo às exigências institucionais e sociais, aquilo que mais se faz não é importante e, portanto, não vale a pena ser registrado. Os resultados imediatos são a subnotificação e a desqualificação do trabalho de polícia.

Retomando as cenas das entrevistas, depois de narrar um caso, e quando perguntado sobre que o impelia a eleger o procedimento relatado, a primeira resposta sinalizava que o 
procedimento responde ao lógico a ser feito. Quase a totalidade das respostas apontavam para esse aspecto de ser a reação esperada, mas sem problematizar o processo decisório. Para eles, as suas reações diante de uma ocorrência eram como "é isso que tenho que fazer", mas, sem elaboração, sem se dar conta do leque de possíveis reações ao mesmo caso, como se estivem em um modo de reação automática. Isso indica que a prerrogativa de tomar decisão está invisibilizada na prática cotidiana do policial, e ainda em relação diretamente proporcional à gravidade do evento.

Indubitavelmente, a tomada de decisão acontece. Mas ela está mascarada ou imperceptível por parte desses profissionais. Isso pode ser resultado de múltiplos fatores: mandato policial em aberto (ou com contornos frágeis), negação do poder decisório do policial nas ruas, medo de assumir e se responsabilizar pelas escolhas que fazem nas ruas devido à punição que podem sofrer. Em qualquer das opções, o que está na mesa é que o policial nas ruas tende a negar suas escolhas operacionais atribuindo as suas decisões a fatores externos, em alguns casos e, em outros, a fatores alheios ao seu conhecimento.

\footnotetext{
O problema de como poder controlar o inevitável e justificável poder discricionário disfrutado pela polícia existe em dois níveis: no nível das decisões políticas, para a forca policial como um todo - a avaliação de prioridades para a alocação de recursos e nas estratégias e estilos amplos e gerais -, e nas ações dos policias das tropas, no nível das ruas" (REINER, 2004, p.242).
}

O controle da ação de polícia tem ocupado um espaço privilegiado nas próprias polícias, principalmente no âmbito público. E, possivelmente, esta venha a ser uma das maiores pressões enfrentadas pelas polícias, a qual se reflete na atuação dos policias nas ruas. Diante da incerteza, o caminho mais provável é a negação da decisão, da autonomia empírica no curso de uma ação para escolher as alternativas a serem empregadas. Como enfatizou o autor, trata-se de uma tensão que perpassa todos os níveis institucionais da polícia. Um profissional, diante de uma 
decisão imediata para definir os meios e a força a ser empregada para garantir uma resposta provisória a um evento, necessariamente faz escolhas.

A resposta policial não é automatizada. Evidentemente, a repetição de tipos de ocorrências pode produzir a introjeção de um modus operandi padronizado. Ainda nesse tipo de situação, a decisão está presente, ou seja, em qualquer intervenção policial junto a uma realidade, a decisão estará presente, pois as pessoas, as condições e outros aspectos da situação se conformam e criam um cenário único. $\mathrm{O}$ aspecto do ineditismo de cada evento cria uma imagem de cores distintas que se pode ver quando as lentes dos óculos somente reproduzem o preto e o branco. Metaforicamente, olhar as ocorrências como uma cena sempre em preto e branco denuncia a negação ou a invisibilidade de uma atribuição vital ao trabalho de polícia, a capacidade de prover soluções imediatas e exclusivas para o caso. E ainda destitui esses profissionais da autonomia inerente à sua função. Isso pode ser consequência de um processo de controle (ou tentativa) da prática policial institucionalmente desenvolvida à luz das pressões sociais e governamentais para a redução da violência e letalidade da ação policial, assim como da corrupção. As decisões essencialmente invisíveis (BITTNER, 2003) não podem ser subtraídas da prática policial nas ruas. Pelo contrário, devem ser assumidas, aceitas para, $a$ posteriori, ser controladas.

Em termos de pontos a destacar na narrativa dos policiais entrevistados, chama a atenção a questão tempo de trabalho, pois esse também impacta a tomada de decisão dos profissionais nas ruas. Há uma relação entre tempo de serviço e experiência, evidentemente. Quanto maior o tempo de trabalho, mais se acumula experiência. Em relação a isso, os policiais com mais tempo de trabalho nas ruas são os que mais indicam sua experiência como um fator significativo no processo decisório. No entanto, os recém-formados referenciam mais a formação policial como importante para a escolha das alternativas de resposta a ser adotada. 
Quanto maior o tempo de trabalho, mais distantes estão os conhecimentos apropriados na formação e, assim, os conhecimentos empíricos resultantes da prática nas ruas e acumulados durante os anos de serviço passam a ter um peso maior. Em ambos os casos, porém, tanto a experiência profissional como o conhecimento acadêmico foram indicados como fatores secundários. A primeira resposta sobre o que determina a escolha por procedimentos indicava não clareza sobre o momento de decidir, de fazer escolhas instantâneas e, por não ser um processo claro, a tomada de decisão permanece em uma zona de opacidade (MONJARDET, 2003), na qual como decido sobre o que fazer nas ruas não é tema de análise individual, nem institucional.

Considerando que a atuação de polícia está inscrita em um universo de possibilidades de demandas, e obviamente por um arsenal de alternativas frente ao ocorrido, a imprevisibilidade da situação desempenha um papel preponderante na tomada de decisão. Tomando como exemplo um tipo de evento recorrente na narrativa dos policiais entrevistados, a violência doméstica contra mulheres, a esse tipo de situação foram descritas ações policiais mais procedimentalizadas, em que o passo a passo da resposta operacional policial estava mais bem definido, devidamente apoiado no conteúdo de matérias que tratavam desse tema no período de formação.

Nesse sentido, pode-se aferir que, nos tipos de casos nos quais a atuação está prevista em leis e transcrita em protocolos de atuação estudados na formação policial e promovidos por políticas públicas, a formação é apontada como base para a escolha do procedimento adequado ao caso. A resposta operacional policial nesse tipo de situação é considerada padrão, para eles. Com isso, os casos mais estudados (e, novamente, evidencia-se que são os eventos que se encontram na pauta do dia, como acontece com as violências intrafamiliares e de gênero) podem gerar menos dúvida em termos de qual o procedimento a ser adotado. E, desse modo, tornar-se mais claro para os policiais quais as bases da tomada de decisão. 
Seguindo com o exercício de problematização do processo decisório do policial nas ruas, mesmo, nesses casos, resta uma questão: a despeito da procedimentalização de casos, como apontado anteriormente, nas ruas, o policial pode ou não seguir à risca o procedimento operacional padrão. Ainda assim, está na esfera de decisão do profissional seguir, alterar ou rechaçar o padrão. Nas ruas, o policial tem um grau de autonomia informal, que lhe é facultativo. Informal porque não é reconhecido nem autorizado institucionalmente, mas indiscutivelmente concreto.

As entrevistas no Rio de Janeiro com os policiais da UPP Santa Marta resultaram em relatos importantes sobre a perspectiva da atuação policial em uma comunidade ou favela. Primeiramente cabe aqui uma problematização: comunidade ou favela ${ }^{59}$ ? Na maior parte das vezes onde os policiais entrevistados fizeram referência ao morro Santa Marta, utilizaram a expressão comunidade. Em geral, comunidade é uma forma de intitular o que antes se chamava favela, de modo a dissimular o impacto que causaria a expressão favela, por já vir carregada de impressões negativas, historicamente construídas na cidade carioca, desde o século XIX. Em outras palavras, o vocábulo passa a ser empregado como um eufemismo de favela. No contexto policial, a expressão comunidade foi adotada na política de implementação das UPPs como definição do espaço territorial onde as UPP estão ou serão implantadas. A comunidade empresta o seu nome à UPP. Para esse trabalho, a UPP se encontrava no morro Santa Marta, chamandose, desse modo, UPP Santa Marta.

Assim como os policiais colombianos, os policiais da UPP entrevistados apresentaram dificuldade de contar um caso no Santa Marta. Segundo os relatos, os casos mais frequentes são: "Mais estica de drogas, usuários mesmo...mais isso. É, assim, coisas bobas, coisa banal: som alto, violência doméstica, socorrer alguém, nada, assim, demais” (Policial UPP).

\footnotetext{
${ }^{59}$ Silva e Barbosa (2005), em "Favela: alegria e dor na cidade", problematiza e contextualiza a adoção da expressão favela na história carioca. Segundo os autores "O eixo de representação da favela é a noção de ausência. Ela é sempre definida pelo 'não teria', um lugar sem infraestrutura urbana - agua, luz, esgoto, coleta de lixo -, sem arruamento, sem ordem, sem lei, sem moral e globalmente miserável. Ou seja, o caos” (p.24).
} 
Novamente, a questão da não identificação de casos de baixo potencial ofensivo ou não criminais, como casos de polícia, se repetiu. Do mesmo modo como foi narrado pelos policiais colombianos, a população local recorre aos policiais da UPP para resolver questões do cotidiano, que não envolvem criminalidade. Como resultado, a narração de um caso no Santa Marta foi um exercício difícil porque a imagem de um policial em ação diante de um episódio de polícia não é recorrente nessa comunidade, para eles. O Santa Marta "é tranquilo", o que significa que as ocorrências ditas criminais não fazem parte do cotidiano desses policias. Nesse aspecto, a concepção da natureza do trabalho de polícia para os entrevistados em ambos os países é compartilhada. Ao narrar o grosso do trabalho que desempenham no morro, foi dito:

\begin{abstract}
Mais assistência social. Policiamento, hoje em dia, a maioria das ocorrências de rua, $70 \%$ é de assistência social. Se for olhar, no Rio de Janeiro, tem muita área na área vermelha, na faixa vermelha que não tá tendo só assistência social. Se for olhar, já é mais $50 \%$ criminalidade. (Policial UPP).

Não é coisa de policial. Mas a gente faz essa função. O policial, hoje em dia, ele faz muita ocorrência que não é do policial. Ele acaba pegando. O policial, hoje, aprende a ser bombeiro, vira guarda municipal...(...). No currículo dele, ele aprende várias profissões. (Policial UPP).
\end{abstract}

A maioria é coisa de marido e mulher. Marido que bateu na mulher, ou, então, uma briga de vizinho. (Policial UPP).

No caso da UPP, diferentemente dos policiais da Comuna 13, as situações não criminais ou "assistenciais" acabam produzindo frustação. Para esses policiais (e talvez para grande parte dos policiais em geral, já que operam segundo a lógica da produção da obediência para assegurar uma solução imediata e provisória ao evento), oferecer os meios para gerar o resultado que - em sua concepção - a pessoa vitimizada deveria desejar e não o fazem, é motivo de frustração. A recusa da solução policial provisória se converte em frustração, por acreditarem que a sua intervenção não modifica as dinâmicas locais. E, por isso, concluem que a ação policial nesse tipo de caso é ineficiente, desnecessária, dispensável. Uma narrativa sobre um 
caso de violência doméstica contra a mulher, em que o policial tentava convencer a vítima a tomar algumas medidas, exemplifica essa situação:

Falamos pra ela era que o melhor pra ela, pra ver se acaba isso de uma vez por todas. E que sempre que ela ligar pra polícia, que solicitar, que é demais porque a gente fica naquilo de vai lá, chega lá e você não quer denunciar. Tem que socorrer? Tem. Mas adianta você ir lá socorrer e a pessoa não quer ir na delegacia dar uma queixa? (...) Isso complica o trabalho da polícia. (Policial UPP)

A UPP foi concebida como um projeto de polícia comunitária adaptado à realidade das favelas. Os policiais alocados nessas unidades têm conhecimento que o trabalho de polícia nesses territórios é distinto e vai consolidando-se de acordo com as dinâmicas locais. Segundo um relato, a noção de polícia comunitária é assimilada da seguinte forma:

A comunidade interage com a polícia em si, tipo para, fala...não generalizando, não todo mundo, mas a grande maioria..... gente almoça no meio do morro ali, entendeu? Pra gente poder interagir com o pessoal. (Policial UPP).

No entanto, mesmo tendo uma noção da proposta de policiamento comunitário em favelas, segundo a perspectiva de pacificação, percebeu-se um inconformismo com o papel comunitário por parte dos policiais entrevistados. Diferentemente da realidade colombiana, no Rio, essas atividades produzem um mal-estar nos policiais, que acreditam estar assumindo uma função, que, além de não ser sua, rouba o policial do seu real dever: o enfrentamento à criminalidade.

Eu acho que o policial tinha que priorizar um pouco mais o proteger. É claro que dentro de uma legalidade, e deixar com que pequenas coisas fossem resolvidas pela própria população, e por outras forças também, como, no caso, a Guarda Municipal. Eu acho que a polícia tinha que se impor um pouco mais, até pra poder adquirir ou recuperar o respeito, e mostrar, de fato, pra o que veio. (Policial UPP). 
Novamente, o não reconhecimento da ação policial em situações de baixo potencial ofensivo ou nãno criminal se manifestou na percepção dos entrevistados. A perspectiva estigmatizante do policial considerado não operacional ou não combatente -aqueles que trabalham no policiamento comunitário ou em unidades policiais especiais que implantaram a filosofia de polícia comunitária, como nas UPP - não é recente. Em momentos passados da história da PMERJ na cidade, em outras iniciativas, como o GPAE ${ }^{60}$ (Grupamento de Polícia para Áreas Especiais) - considerada uma versão anterior da mesma proposta UPP, servindo de inspiração a esta -, os policiais eram associados à imagem de "policiais cor de rosa", "policiais de mentira", "faz tudo da favela" (CARUSO, PATRÍCIO \& ALBERNAZ, 2010), por seus próprios colegas de outras unidades.

A referência de trabalho de polícia, na forma como é entendido pelos próprios policiais, é associada à imagem do combatente, truculento. A percepção do policial menos importante e "faz tudo" ainda prevalece junto aos policiais entrevistados da UPP. E, assim, eles também acreditam que "não [o trabalho não é de polícia]. Mas como na vida todo mundo é mil e uma utilidades, né?” (Policial UPP).

Sobre esse ponto, comparando-se à percepção dos policias colombianos e brasileiros entrevistados sobre trabalho de polícia, verifica-se que ambos os grupos acreditam que os casos não criminais não têm essa natureza. No entanto, o que difere um grupo do outro reside na forma como lidam com essa questão. Na Colômbia, eles acreditam que fazem esse tipo de trabalho porque não há outro profissional que o possa cumprir, e que estão qualificados para isso (no sentido legal e com legitimidade). Já no Brasil, compartilham a visão de que as ocorrências não criminais não são trabalho de polícia, entendendo, porém, que outros profissionais poderiam fazê-lo (como guardas municipais, bombeiros, assistentes sociais etc);

${ }^{60}$ Sobre o GPAE, ver: Como Morre um Projeto de Policiamento Comunitário: o caso do Cantagalo e do PavãoPavãozinho (CARDOSO, 2010); Análise Comparada de Modelos de Controle da Polícia via Participação Social (HOLANDA, 2005). 
e, ainda mais importante, acreditam que estão empregando mal seu temo de serviço, pois poderiam estar dedicados ao "combate à criminalidade". Assim, resumidamente, atendem a esse tipo de problemática na comunidade, mas insatisfeitos, frustrados.

A narrativa dos policiais entrevistados esboça uma visão de mundo em que a imposição da obediência por meio da força parece supervalorizada. Os casos contados, nos quais a dramaticidade do evento demandou reações desse nível de força, foram citadas de maneira mais esfuziante, ou como se diz popularmente, "com a boca cheia”. Esses casos não ocorreram na UPP, mas permaneciam nas lembranças dos entrevistados como "casos de polícia". O tema em jogo é a autoridade colocada em ação por meios mais agressivos. É inegável que há situações nas quais a polícia não negocia os meios nem os fins para alcançar a obediência. Esses são, sobretudo, os crimes violentos. Reiner reflete sobre a relação entre reconhecimento do poder de polícia - e o seu poder decisório nas ruas por consequência -, bem como os conflitos sobre o mandato policial, indicando que esse exercício de reflexão se torna inevitável (e premente) para o avanço na definição do trabalho de polícia. Em suas palavras:

\footnotetext{
As evidências históricas e sociológicas deveriam ter esclarecido que o combate ao crime nunca foi, não é e não pode ser a atividade principal da polícia, embora isso faça parte da cultura policial e da mitologia exposta pela mídia e, em anos recentes, da política do governo. O mandato principal do policiamento, historicamente e em termos de demandas concretas colocadas a polícia, é o de manutenção da ordem, que é mais difuso. Somente se isso for reconhecido, realmente poderão ser confrontados os problemas a respeito dos poderes da polícia e da sua responsabilização em toda a sua complexidade. (REINER, 2004, p. 243).
}

Considerando que a obra original do autor data de 1992, pode-se ponderar que, passados mais de vinte anos, não se reconhecem avanços significativos sobre a questão do mandato policial, e que tampouco este tenha sido tema de análises contundentes.

Ao analisar, comparativamente, as narrativas dos policiais colombianos e brasileiros sobre o trabalho de polícia, algumas distinções saltam aos olhos: (i) os colombianos apresentaram sua prática com ênfase na perspectiva de resolução de conflitos por meios 
pacíficos como prioritário; os brasileiros, a despeito de estarem em uma unidade "pacificadora", preservavam e valorizam as características mais combatentes do trabalho de polícia; $(\mathrm{ii})$ a autoridade policial é mais imposta no cenário carioca, do que na experiência colombiana, ou seja, o reconhecimento da autoridade policial para resolver o problema por parte da comunidade não acontece espontaneamente. Há uma descrença generalizada na efetividade do trabalho de polícia. Já na Colômbia, os policiais são mais bem aceitos e demandados, gozando de mais confiança nos meios que vão adotar para produzir obediência e, como consequência, oferecer uma solução ao caso.

Um dos policiais entrevistados da UPP narrou um episódio no qual, mesmo em uma situação de baixo risco - pois se tratava de levar um suspeito autor de violência doméstica contra sua companheira -, a ação da polícia se apresenta ameaçadora e violenta. A cena narrada refletiu a violenta cultura policial, que não se pacificou para pacificar o morro. A imposição da obediência se concretizou da seguinte maneira:

Deu um problema com tua esposa aí. Então, tu vai ter que vim com a gente. Mas depende de você, depende muito do cliente. Você vai! De alguma forma ou de outra. Você vai como? No amor ou na dor? (...) Precisa te algemar? (...) Se você correr, eu vou correr atrás de você, e vou te pegar. Mas eu vou te dar um pesadão, que vai você voar lá em baixo nas escadas. (Policial UPP).

Acerca do tema tomada de decisão, nas entrevistas quando indagados sobre o que levam em conta no momento decisório, majoritariamente as respostas se concentraram em explicações acerca do procedimento adotado. Eles explicavam o que fizeram repetidamente, sem, no entanto, fazer alguma elaboração reflexiva sobre o processo de decidir entre as alternativas possíveis para o caso. Foram realizadas algumas tentativas de retomar o tema de maneira diferente, que geraram algumas respostas. Essas respostas apontaram para um tipo de ação policial que não passa pelos mecanismos cognitivos. A justificativa para isso era uma resposta "automaticamente" produzida para alguns. Para outros o "instinto" aparece como autor da resposta policial. Ambas ilustradas nas falas abaixo: 
Na hora, é automático, porque a sociedade espera isso da gente. Isso não seria uma opção, neh? A gente tá passando ali, eles estão informado a nós; nós somos autoridade, e, tipo assim, a gente vai cagar, né? Não, não pode. (...). Não podemos omitir esse socorro...vom bora! Foi no automático, né? (Policial UPP).

O próprio rato, quando a gente encurralar um rato, botar o rato num canto, ele vem em cima de você, se você vier pra pegar ele. Pode ter certeza. O policial é assim, em momentos de encurralar. (Policial UPP),

Parece uma memória muscular...você vai fazer involuntariamente. É igual andar. Tu vai levantar e vai andar, e dizer ué, to andando. Você tava passando mal, perna doendo, aí de repente dá um problema, a adrenalina sobe, e você vai correr...não to sentindo nada na minha perna. Você teve que fazer aquilo, involuntariamente. (Policial UPP).

Essa concepção do automatismo irreflexivo ou instinto animal da resposta policial indica que não há como identificar a razão de ser da reação, isto, os fatores e insumos que produziram a resposta. No sentido da ausência dos elementos explicativos para a escolha diante de um evento, alinha-se a visão de que a prática vai elaborando um modus operandi distinto em cada situação enfrentada. Isso seria traduzir a resposta policial como uma reação cuja base da decisão não é identificada. Essas duas perspectivas também foram compartilhadas pelos policiais colombianos. Em ambos os grupos, há policiais que não identificam a origem das escolhas adotadas no momento do acontecimento, no processo decisório, na decisão tomada para garantir obediência.

A outra perspectiva de resposta policial narrada se centrou na adoção do procedimento operacional padrão para resolver o caso. O procedimento operacional padronizado pela polícia foi apresentado como uma obrigatoriedade, o que não lhes permite "fazer de outra forma", espécie de camisa de força que impede o policial de tomar qualquer outro rumo diante de um evento. Essa noção de aprisionamento operacional pelo padrão também foi apontada pelos policias colombianos entrevistados. Esses dois grupos se entendem como reféns da padronização operacional. É interessante notar que eles não se concebem como autores de sua prática, como portadores da prerrogativa da decisão sobre os meios (e grau de intensidade dos mesmos) que podem fazer uso para assegurar uma solução provisória. 
Porque já é o padrão. Você [enquanto] policial, o procedimento é abordar. Você identificou que é um criminoso, identificou que ele tem uma arma, tal.... Você prender, né? Você ver qual o tipo de ocorrência que tá acontecendo, se é tráfico, se ele tá com uma faca, se é outra coisa. Você chamar a supervisão, ligar pro 190, explicar o caso, fazer o boletim, ir pra delegacia...é tudo um procedimento, né? A gente não faz nada por vontade própria. (Policial UPP).

Evidentemente, essa perspectiva somente se concretiza no campo da retórica, das ideias, porque, definitivamente, o fato de escolher o uso de um procedimento operacional padrão já se constitui per si como uma escolha diante de outras alternativas possíveis.

Se, por um lado, não conseguem identificar a base para a sua tomada de decisão no ato da ação, por outro apontam os procedimentos que devem ser tomados para referenciar a resposta policial. E, ainda mais curioso, é que se expropriam de qualquer possibilidade de intervenção, desde a sua autonomia para escolher quais os meios utilizarão para dar algum encaminhamento ao caso. Verifica-se que há um processo de destituição de autoridade, pelo menos no campo da formalidade, em relação ao que é inerente e intrínseco no trabalho de polícia: a decisão sobre o que fazer, e como fazer, para alcançar a aprovação da sociedade e manter-se sob a proteção da lei. A ação na medida certa de justiça, circunscrita na dimensão empírica de técnicas e estratégias para o monopólio legal da força, não pode ser concebida como um resultado simplista do cumprimento de procedimentos operacionais padronizados, ou, pelo acaso, ou qualquer outra justificativa que desqualifique a ação policial e lhes destitua a posição de autores conscientes de sua ação, que elaboram a resposta a uma solicitação cotidianamente. Esse cenário revela que todo o processo decisório está sendo invisibilizado, negado e desqualificado.

A questão da prerrogativa de decisão, não apontada pelos entrevistados, reflete uma noção de profissionais sem liberdade de escolha, que seguem ora um instinto, ora um padrão de procedimento operacional, ora avaliam que o automatismo constitui o motor da tomada de decisão. Em nenhuma das concepções apresentadas, há traços de análise ou reconhecimento do processo decisório ou apropriação do espaço de decisão. Esse processo pode ser compreendido 
como uma alienação de parte intrínseca à atividade laboral policial, decisão diante de alternativas legais e legítimas para produzir obediência.

Sem a discricionariedade do policial, a ficção substituiria a realidade, e as polícias seriam formadas por robocops, que cumprem fielmente um programa cuja resposta já programada seria ativada automaticamente, sem nenhuma interferência. Esse é um ponto comum entre ambos os grupos.

Por outro lado, vale destacar que não houve menção por parte dos policiais entrevistados nas duas polícias sobre os mecanismos institucionais de suporte para o processo decisório. Isso significa que as ferramentas disponibilizadas para subsidiar a prática policial nas ruas e a escolha entre os procedimentos padronizados não funciona como uma fonte de consulta ou apoio. Tanto a PDA colombiano quanto os POPs adotados na PMERJ não servem para aquilo que foram criados, segundo esses dois grupos. 


\section{CONSIDERAÇÕES FINAIS}

Este trabalho foi provocado pelo interesse de compreender o que parecia mais intrigante acerca do trabalho de polícia nas ruas: tanto os mecanismos ou insumos que os policiais contam para tomar a decisão nas ruas, quanto escolher quais procedimentos devem adotar, diante de um dado evento.

Não se trata de uma questão simples quando se debruça sobre o tema do trabalho policial. Aqui cabe reforçar que o foco de atenção desta pesquisa foi o exercício do trabalho de polícia nas ruas Tomou-se como ponto de partida o fato de a polícia ter uma sorte ampla de atribuições em distintos campos, como investigação criminal, perícia, salvamento e resgate, etc., delimitar a observação sobre a prática policial nas ruas significa restringir para aprofundar.

Igualmente cabe pontuar que, em alguns momentos do texto, foram utilizadas as expressões policial brasileiro e policial colombiano. Sobre isso, cabe esclarecer que tais expressões não foram usadas com o sentido generalizante. Por policiais brasileiros se compreende um grupo sem fim de profissionais com papéis, atribuições e cultura organizacionais distintos. No Brasil, há duas polícias de âmbito estadual em cada unidade federativa (militar e civil), duas polícias federais (federal, rodoviária federal) e a Força Nacional. Em âmbito municipal, as guardas municipais também são instituições que atuam no campo da segurança pública. Com isso, fica evidente que não se pode generalizar e utilizar a expressão policial brasileiro como referência válida. No texto, seu uso foi apenas para distinguir o grupo de policiais cariocas (brasileiros) dos policiais colombianos.

Com relação à expressão policial colombiano, a despeito de qualquer generalização incorrer no risco de representar ninguém e um falso todos, o caso colombiano tem características diferenciadas, que devem ser expostas. A Colômbia é um país centralizado, e a PONAL, seguindo essa perspectiva, possui um comando nacional e diretrizes nacionais para 
todas as unidades de polícia do território colombiano. A partir do comando nacional, a formação policial é definida, assim como todas as demais funções policiais. Nesse sentido, foi possível apreender um modus operandi compartilhado pelos policiais de rua, em distintas cidades onde estive - Bogotá, Medellín, Cartagena e Quibdó.Ainda assim, não se pode inferir que há uma figura do policial colombiano, que representa a todos em nível nacional. No entanto, há elementos que se repetem e que emprestam a esses policiais uma impressão de universalidade em termos de abordagem policial. Sob esse aspecto, as duas polícias se distinguem, pois, no caso brasileiro, cada unidade federativa goza de autonomia para gerir as polícias locais, que estão subordinadas ao governo local.

A respeito da inquietação sociológica norteadora desse trabalho, que se desdobra nas perguntas: o que é levado em consideração no momento de tomar uma decisão diante de uma situação para qual a polícia foi demandada a atuar? Como se define o que tem de ser feito em cada caso atendido?, há algumas considerações que devem ser apresentadas.

De modo geral, foram identificadas algumas questões em cada um dos grupos de entrevistados, as quais merecem ser pontuadas. No que tange à expressão de concepções do trabalho de polícia e valores policiais capturados nas narrativas dos entrevistados, cabe sinalizar que os policiais da UPP Santa Marta se valeram de análises que indicam uma prática que valoriza mais a experiência de trabalho do que a formação. Isso, talvez, possa ser explicado pelo fato de a realidade carioca ser compreendida como um cenário de guerra, de violências extremas e cotidianas, de situações em que o policial se vê diante da percepção de morte iminente. Essa não é uma realidade do Santa Marta, mas os policiais não permanecem na mesma unidade policial por toda a sua vida funcional, acabam sendo transferidos para outras UPP e até para batalhões tradicionais. 
Na polícia [na formação policial], no patrulhamento tático, não é uma coisa como lição real. Não é um bandido como uma AK47. Nós ali estamos com um FO [fuzil ordinário], que é um armamento letal, mas desmuniciado. (...) não se compara com o que você vê. Aqui no Rio de Janeiro, é uma guerra civil...fuzil, é complicado. (Policial UPP)

A percepção de guerra impacta sensivelmente a concepção do trabalho de polícia, segundo os entrevistados. Nesse contexto, a experiência nas ruas é supervalorizada, funcionando como uma salvaguarda para eles. Para os policiais colombianos, ainda que a experiência laboral também tenha um peso maior do que a formação na escola de polícia, a formação também é considerada importante. No caso brasileiro, os policiais não compreendem o processo de formação como relevante para a realidade das ruas. Essa questão pode ter suas raízes na própria formação.

Na Colômbia, a formação está bem organizada em termos de equipe de profissionais exclusivamente dedicados à função do ensino, de estrutura das escolas, de parâmetros nacionais para a grade curricular nacional. Nas escolas de formação de patrulleros, há docentes selecionados para cada disciplina, de acordo com sua a experiência no tema a ser ministrado. O CEFAP, escola de formação de praças, conta com uma estrutura mais precária, na qual o corpo discente acaba servindo de mão de obra extra em atividades de policiamento ${ }^{61}$, e, com isso, o tempo de formação acaba sendo reduzido. Essas distinções podem explicar a visão diferenciada sobre o peso da formação para a prática policial nas ruas.

Nesse sentido, mesmo havendo relatos que apontaram a formação como relevante e adequada, a questão da preponderância da experiência sobre o ensino formal foi consenso. Outra especificidade em relação à experiência, no caso brasileiro, foi a experiência de vida dos policiais cariocas como fator relevante. Segundo eles, a origem social dos policiais militares do Rio é popular e, em geral, são (ou foram) moradores de favelas ou áreas próximas. Isso lhes

\footnotetext{
${ }^{61}$ Sobre o processo de formação na PMERJ, veja Caruso (2006).
} 
agrega uma experiência anterior à entrada na polícia em contextos de violência, corroborando com a sua experiência profissional.

Eu vim de um lugar.... é que eu moro próximo a uma comunidade. Eu vivenciei isso. Eu sei que que é um tiroteio. Sei que que é tiro aqui, tiro lá. Sei que que é ver alguém morto no chão. Eu, por exemplo, sou um policial que não vim da classe média, vim da classe pobre. Eu vim da comunidade, eu sei como é. (Policial UPP).

O lugar de fala desses policiais se encontra no centro da problemática que, na atualidade, lidam desde outra perspectiva: a de um professional de segurança pública que tem como missão genérica a preservação da paz e da ordem. Ordem e paz que não foram experimentadas no período de vida desses profissionais, mas sim como uma retórica revestida por uma política pública. Por outro lado, a percepção de violência relatada pelos entrevistados colombianos provenientes, principalmente, de cidades pequenas, era de surpresa e temor pela violência em Medellín. Segundo os depoimentos, esses policiais viveram a maior parte das suas vidas sem contato com a violência urbana cotidiana e difundida nas grandes cidades colombianas. Em muitos relatos, declararam que não haviam presenciado consumo e venda de droga em lugares públicos, além de crimes urbanos, como roubo, furto, etc, até chegarem a Medellín. Consideram ainda que a formação policial impactou suas visões de mundo, pois tiveram contato com conteúdos relacionados a valores cívicos, planejamento familiar e outros temas correlatos nas disciplinas do curso de formação.

Os valores espirituais e morais perpassam o processo de formação e a instituição policial colombiana. Em um de seus símbolos - o seu escudo - lêem-se as palavras de ordem Dios y Patria. Essa é uma máxima adotada, inclusive, na comunicação verbal da instituição. Ao fazer uma chamada telefônica para a PONAL, a comunicação se iniciará com “dios y pátria, buenos días/ buenas tardes/ buenas noches". Na Colômbia, a formação fortalece valores culturais da sociedade colombiana, reforça aspectos de formação de caráter como parte da formação para 
um "buen profesional", além das disciplinas tradicionais. Ao passo que no Rio de Janeiro o foco da formação é a atuação policial, ou seja, disciplinas relacionadas aos conteúdos programáticos da formação policial militar.

Outra questão que deve ser comentada é a aplicação legal e legítima da força e da autoridade em ambas as polícias. Na Colômbia, o policial tem como regra tentar iniciar o contato com a comunidade a partir do diálogo, para eles, uma valorizada ferramenta de persuasão, empregada com o propósito de estabelecer uma medida de reparação do evento. De fato, eles têm uma postura marcadamente de resolução de conflitos, de maneira dialogada e no próprio local.

No caso carioca, a prática da polícia, segundo os entrevistados, é voltada para o enquadramento do evento na norma penal, em situação de ocorrência criminal, por meio da força real aplicada ou seu potencial uso. Isso se aplica também aos eventos criminais de baixo potencial ofensivo. Em geral, a evocação da lei é a primeira alternativa dos policiais cariocas. A imposição da autoridade segue pela via da norma legal. Para produzir obediência, o policial colombiano segue pela via do convencimento dialogado, como estratégia inicial, enquanto, no Rio, a evocação da lei se configura como estratégia priorizada. Em termos de técnicas policiais, como abordagem, autoproteção, táticas de incursão e outros, ambos os grupos declararam que a escola foi a fonte desse conhecimento.

Os policiais no Rio de Janeiro enfrentam uma realidade marcada pelo enfrentamento violento com a criminalidade, principalmente nas áreas nas quais estão as favelas, resultante da presença (e muito vezes domínio territorial) das facções de narcotráfico. A cidade se destaca no Brasil pela letalidade dos conflitos entre polícia e narcotraficantes, seja em operações nas favelas, seja por ataques aos policiais. Dessa forma, a ação policial é transversalizada pela cultura de guerra, que perpassa todas as atividades policiais. O impacto desse cenário pode ser 
percebido nas estratégias de solução provisória de conflitos, que não privilegiam o diálogo, mas sim a imposição da autoridade por meio da lei ou da opressão.

Medellín, por sua vez, experimetou anos de chunbo e sangue no período no qual o narcotráfico enfrentava a força pública com violência e atos de terrorismo. Passado a fase mais violenta, o governo local e o governo nacional deram início a diversas ações de segurança pública, melhoramento das condições de trabalho, capacitação de policiais e investimentos em tecnologia e equipamento. Esse esforço governamental vem sendo desenvolvido há algumas décadas, com presumíveis mudanças relativas a gestão em vigor, porém, com a presenvacao de pilares significativos para a política de seguridade ciudadana. Esse contexto oferece elementos explicativos para a postura mais comunitária do policial de Medellín quando comparado ao carioca.

Vale reiterar que a proposta desse trabalho não era realizar uma avaliação sobre a ação da polícia nas cidades pesquisadas. No entanto, cabe sinalizar que os contextos de atuação com traços culturais e singularidades emprestam ás realidades dos policiais contornos e nuances distintos, considerados chave para a compreensão das diferenças apresentadas.

Outro ponto a destacar é que, em ambos os grupos entrevistados, a dificuldade de contar um evento foi presenciada. A Comuna 13 e o morro Santa Marta reportam, majoritariamente, casos de baixo grau de violência como as violências intrafamiliares e contra mulheres, e casos não criminais. Como esses são os atendimentos policiais mais recorrentes, eles não encontram casos para contar, pois não os consideram casos de polícia, conforme afirmaram os policiais entrevistados.

Sobre a questão dos elementos que influenciam a escolha da alternativa a ser aplicada para produzir obediência, frente a uma situação em um determinado local, cabe fazer a seguinte reflexão. Primeiramente, é preciso identificar os fatores que interferem no processo decisório, com base nos relatos coletados. São eles: tempo de serviço policial e experiência decorrente, 
formação e gravidade do caso. Esses fatores foram apontados como elementos que influenciam a tomada de decisão. Entre eles, a experiência profissional foi, por consenso, o que mais impacta na hora de se tomar uma decisão nas ruas. A experiência de trabalho foi pontuada como sendo um acervo pessoal no qual se pode buscar algum tipo de resposta ao que se apresenta no momento em questão. A respeito da gravidade da situação, nas narrativas foi possível observar que, nos casos de maior o potencial ofensivo e mais risco de morte, o policial se sentiu excessivamente pressionado a tomar uma decisão e escolher um procedimento operacional efetivo que assegurasse o resultado esperado, e rapidamente ainda. O fator tempo é determinante nos momentos em que a decisão tomada pode salvar vidas, ou não. E são esses os casos nos quais mais evocaram o instinto como mecanismo determinante para a escolha.

Todavia, esses foram identificados como fatores relevantes e não determinantes, de acordo com os relatos. A pesquisa buscou identificar quais mecanismos poderiam ser reconhecidos como determinantes das escolhas por procedimentos aplicados nas distintas situações que integram a prática policial nas ruas. No entanto, os policiais entrevistados de ambos os grupos não conseguiram identificar em sua ação o fator determinante para produzir obediência. O processo decisório, de fato, ficou invisibilizado ou negado para os grupos entrevistados. Em suas respostas, eles atribuíram as escolhas a fatores que não passam pela racionalidade nem pela cognição, já que indicaram o instinto e o automatismo como determinantes.

Com isso, o que se apreende de suas narrativas pode ser concebido como um processo de alienação da própria prerrogativa de tomar decisões, de fazer escolhas e de agir ou reagir segundo as alternativas escolhidas. A característica mais contundente do trabalho de polícia nas ruas é justamente lidar com uma sorte potencialmente infinita de eventos que demanda do profissional uma resposta imediata, provisória, legal e legítima. A conciliação de todos esses elementos constitutivos da ação policial está sendo expropriada de sua prática. 
Faz-se providencial reforçar que esse fenômeno se processa no campo retórico, analítico, porque, de fato, na prática policial cotidiana é impossível não tomar decisões diante de uma ocorrência de qualquer natureza. Em todos os instantes, esses profissionais são solicitados a decidir o que fazer, como fazer e com qual intensidade serão aplicadas as medidas escolhidas. Tudo isso no momento da execução da ação. Esses momentos solitários de tomada de decisão sempre existiram, e continuam ocorrendo na ação de polícia. A prerrogativa da eleição dos meios e modos de atuação, a despeito de ser negada ou invisibilizada, é intrínseca ao trabalho de polícia.

Cabe indagar: o que leva os policiais a autoexpropriação de uma prerrogativa intrínseca à sua prática? Algumas hipóteses que poderiam auxiliar a responder essa questão: a princípio, os dois grupos entrevistados fazem parte de uma instituição militarizada, cujos princípios da disciplina e da hierarquia são preponderantes. A autonomia na ponta, na qual justamente estão os que compõem os escalões mais baixos da hierarquia, e que fazem polícia, não se configura em um mérito. Ao contrário, a depender da situação, pode resultar em punição. A distribuição de poder para os que estão nas ruas ainda é um assunto que avançou pouco, em âmbito institucional.

É compreensível que um profissional que toma decisões sobre a resposta a ser empregada aos eventos enfrentados cotidianamente, e que com isso corre o risco de ser punido por, possivelmente, contrariar diretrizes ou normas institucionais, opte por não assumir que faz escolhas. Essa é a lógica que garante a ele a sobrevivência institucional. No entanto, esse se torna um jogo de falsas verdades. Por um lado, o policial finge que não decide o que fazer e como fazê-lo; por outro a polícia finge que seus profissionais seguem os padrões operativos nas ruas, sem gozar da prerrogativa da escolha. Esse é um jogo sem ganhadores: o policial nas ruas porque experimenta ambiguidade e contradições na sua prática, medo e baixa capacidade de 
responsabilização pelo que faz; a polícia porque não pode controlar aquilo que não ocorre, ou seja, o controle dos seus profissionais nas ruas se perde.

Outra hipótese seria a questão do mandato policial em aberto. A amplitude do espectro da ação de polícia cria um cenário de possibilidades potencialmente infinito. Para uma profissão como a policial, que deve tirar da cartola uma resposta imediata e efetiva para cada caso, este é um dilema: o que fazer para resolver aquilo que eu ainda não lidei. Evidentemente, há recorrências em termos de casos, que podem produzir um modus operandi padronizado. Mas, mesmo assim, cada caso é um caso. Cada ocorrência possui especificidades, que demandam do policial a capacidade de forjar uma (pronta) resposta.

Essas são hipóteses que servem ao exercício proposto de tentar identificar a razão de ser desses fenômenos de invisibilização ou negação do processo decisório. Ao que parece, há um conhecimento ou um saber resultante da experiência de vida, da prática nas ruas, dos conhecimentos absorvidos na formação e nos espaços de capacitação e aprimoramento, que informam e formam a práxis policial. Constrói-se e dramatiza-se, portanto, nas nas ruas uma sabedoria elaborada sem mediação com base na realidade das esquinas, nas cenas da tragédia humana.

No começo a gente sai do curso, vem pra realidade, a gente fica meio assim. Ai depois a agente vai se acostumando, a gente consegue avaliar as pessoas que tão próximas da gente. Só de ver já sabe que o perigo tá perto. Tem situações da gente descer o morro, e o morro tá tranquilo. Mas tem dia, que a gente desce a comunidade e já sabe que o clima tá diferente. (Policial UPP).

Ainda que seja parte inerente de sua experiência laboral, a faculdade de decidir, assim como a riqueza e a diversidade de conhecimentos, saberes e sabedoria estão sendo oficialmente negados, além de oficiosamente exercidos. A dicotomia presente nesse cenário revela que o debate sobre o poder decisório do policial nas ruas não está esgotado, mas, ao contrário, ainda se encontra em estado embrionário. Portanto, esse é um assunto importante e urgente para o 
policial que está nas ruas, assim como para a polícia. Do ponto de vista institucional, os investimentos voltados para a formação e o aperfeiçoamento da prática policial, especificamente sobre o aspecto mais significativo da ação de polícia - o processo decisório diante de um evento -, parece não estar sendo contemplado. Pelo menos não de forma satisfatória a ponto de produzir algum impacto na concepção dos profissionais entrevistados.

Acerca do caso colombiano, vale sublinhar que, na narrativa dos patrulleros entrevistados, a questão do acordo de paz que estava na iminência de ser assinado entre o governo colombiano e as FARC-EP não figurou em suas reflexões. Considerando-se que são esses os profissionais que fazem o policiamento ostensivo, além de e responsáveis por seus cuadrantes - dentro do marco de PNVCC -, isso deve ser um sinal amarelo no que diz respeito ao cenário cambiante que deverão lidar. Com a assinatura do acordo de paz, o país passará a uma fase histórica com grandes repercussões em muitos setores e políticas públicas. Alguns dos temas mais recorrentemente comentados, e que são foco de atenção da gestão pública, estão no regresso dos guerrilleros à vida civil e às comunidades, além de todos os desafios (social, econômico, trabalhista etc) e conflitos que esse retorno pode causar, a possibilidade de ocupação dos territórios deixados pela guerrilha por outros grupos armados, por meio de disputas armadas e violentas e suas implicações na vida das comunidades, entre tantos outras problemáticas.

No caso do Brasil, é importante ressaltar a definição do mandato de polícia, da finalidade da polícia ou do braço armado do Estado em uma sociedade em processo de democratização. A indefinição do uso da força policial provoca - em avalanche - a descontinuidade de currículos de formação policial; a manutenção de perspectivas conflitantes na práticia policial entre o guerreiro combatente - no marco do paradigma da segurança nacional, onde o combate se realiza com os inimigos; e o policial civil a serviço da democracia e da defesa dos direitos dos cidadãos. Discutir a formação policial, o controle da atividade policial, o impacto da atuação 
de polícia, sem definir o que deve fazer a polícia, não atinge o cerne da problemática. Não que seja dispensável ou irrelevante tratar dessas questões, mas desde uma perspectiva crítica, essa situação pode ser comparada a algo como enxugar gelo. Se não se sabe para onde se quer ir, qualquer caminho serve ao andarilho. Para os dois países, essa é uma questão-chave para a adequação das polícias ao que se espera delas, ou seja, definir o papel das polícias.

A esse ponto, cabe sinalizar que este trabalho não pretendeu fazer uma avaliação do trabalho de polícia dos grupos pesquisados, tampouco buscou comparar e hierarquizar os resultados encontrados para apontar qual instituição policial estaria mais adequada aos pressupostos democráticos. Igualmente não pretendeu esgotar o tema do estudo, mas sim, identificar junto aos sujeitos da pesquisa os elementos decisivos para a escolha de alternativas que levem à resolução temporária de um determinado evento.

Ao fim da pesquisa, a resposta encontrada denuncia o panorama que os profissionais mais próximos da população, os que são os representantes mais tangíveis do Estado, contam para fazer suas escolhas: os policias nas ruas negam e invisibilizam sua própria práxis em nome da preservação de um statu quo incompatível com o exercício das atividades de polícia. O reconhecimento da prerrogativa facultada por lei, e exercida na práxis policial, de escolher as alternativas policiais mais adequadas para prover uma solução temporária e imediata deve ser assumida, qualificada e controlada. E essa é uma tarefa prioritária para a consolidação de práticas policiais democratizadas e de polícias que estejam a serviço da cidadania, da proteção de direitos. 


\section{REFERÊNCIAS BIBLIOGRÁFICAS}

ADORNO, Sérgio. Insegurança versus Direitos Humanos: entre a lei e a ordem. Tempo Social, v. 11, n. 2, 1999.

ALBERNAZ, Elizabete R.; CARUSO, Haydée; PATRICÍO, Luciane. Tensões e desafios de um policiamento comunitário em favelas do Rio de Janeiro: o caso do Grupamento de Policiamento em Áreas Especiais. São Paulo em Perspectiva, v. 21, n. 2, p. 39-52, jul./dez. 2007.

Disponível

em:http://www.uece.br/labvida/dmdocuments/tensoes_e_desafios_do_policiamento.pdf

Acesso em 12 de março de 2016.

ÁLVAREZ, Silvia M. O presente permanente: por uma antropografia da violência a partir do caso de Urabá, Colômbia. Tese de doutorado, Brasília, 2012.

ARICAPA, Ricardo. Comuna 13, crónica de una guerra urbana. Universidad de Antioquia. Medellín, 2005.

ARREDONDO, Atehortúa; SÁNCHEZ, Clara Inés; AMPARO, Luz; JIMÉNEZ, Blanca Inés. El conflicto armado afecta todas las esferas. Implicaciones del conflicto armado en la Comuna 13. Revista de Derecho, núm. 32, Universidad del Norte. Barranquilla, 2009. Disponível em: http://www.redalyc.org/articulo.oa?id=85112936006

AZEVEDO, Rodrigo G. Elementos para a Modernização das Polícias no Brasil. In: Revista Brasileira Segurança Pública, V Suplemento Especial, 8-20, v. 10. São Paulo, 2016.

BALLESTROS, Paula R. Gestão de políticas de segurança pública no Brasil: problemas, impasses e desafios. In revista FBS vol 8, 2014.

BAYLEY, David H.; SKOLNICK, Jerome H. Nova polícia: inovações nas polícias de seis cidades norte-americanas. Coleção Policia e Sociedade, vol. 2. São Paulo: EDUSP, 2000.

BAYLEY, David. Padrões de policiamento: uma análise internacional comparativa. Coleção Polícia e Sociedade, vol. 1. São Paulo: EDUSP, 2000.

BITTNER, Egon. Aspectos do trabalho policial. Coleção Polícia e Sociedade, vol. 8. São Paulo: EDUSP, 2001.

BRETAS, Marcos Luiz. Ordem na cidade: o exercício cotidiano da autoridade policial no Rio de Janeiro, 1907-1930. Rio de Janeiro: Editora Rocco, 1997.

. Observações sobre a falência dos modelos policiais. São Paulo Tempo Social;

Rev. Sociol. 9(1). São Paulo: USP, 1997.

BRODEUR, Jean-Paul. Como reconhecer um bom policiamento: problemas e temas. Coleção Polícia e Sociedade, vol. 4. São Paulo: EDUSP, 2000. 
BURGOS, Marcelo Baumann; PEREIRA, Luiz Fernando Almeida; CAVALCANTI, Mariana; BRUM, Mario; AMOROSO, Mauro. O efeito UPP na percepção dos moradores das favelas. Desigualdade \& Diversidade - Revista de Ciências Sociais da PUC-Rio, n ${ }^{\circ}$ 11, 2011. Disponível em: http://desigualdadediversidade.soc.puc-rio.br/media/4artigo11.pdf Acesso em 12 de março de 2016.

CANO, Ignácio. Letalidade da ação policial no Rio de Janeiro: a atuação da justiça militar. Rio de Janeiro: ISER, 1999.

CANO, Ignacio; BORGES, Doriam; RIBEIRO, Eduardo. Os donos do morro: uma avaliação exploratória do impacto das Unidades de Polícia Pacificadora (UPPs) no Rio de Janeiro. Rio de Janeiro: Heinrich Boll Stiftung, 2014.

CARDOSO, Marcus. Demandas por direitos e a polícia na encruzilhada. Revista Brasileira Segurança Pública, v. 8, n. 1. São Paulo, 2014.

CARRIÓN, Fernando. Reforma policial. In: Ciudad Segura: Debates sobre seguridad ciudadana. Ecuador: FLACSO, 2007.

CARUSO, Haydée. Polícia Militar do Estado do Rio de Janeiro: da escola de formação à prática policial. Relatório Final da Pesquisa da Senasp, 2006.

CARUSO, Haydée; PATRICIO, Luciane; MENDONÇA, Nalayne. Da Escola de Formação à Prática Profissional: um estudo comparativo sobre a formação de praças e oficiais da PMERJ. Segurança, Justiça e Cidadania: Pesquisas Aplicadas em Segurança Pública. Brasília: Segurança, Justiça e Cidadania / Secretaria Nacional de Segurança Pública do Ministério da Justiça, n. 04 - Ano II, 2010.

CERQUEIRA, Carlos Magno Nazareth. As políticas de segurança pública do governo Leonel Brizola. In: Crime organizado e política de segurança pública no Rio de Janeiro. Arché Interdisciplinar, ano.7, n. 19. Rio de Janeiro: Universidade Cândido Mendes, 1998.

CHAK, Wong Sio. A filosofia e modelo de policiamento comunitário - concretização e percepção por parte da PJ. Biblioteca Virtual da Polícia Militar de Alagoas. Disponível em: http://www.pm.al.gov.br/intra/downloads/bc_policial/pol_07.pdf . Acesso em 13 de novembro de 2015.

COSTA, Arthur T. M. Entre a lei e a ordem: violência e reforma nas polícias do Rio de Janeiro e Nova York. Rio de Janeiro: Editora Fundação Getúlio Vargas, 2004.

As reformas nas polícias e seus obstáculos. Uma análise comparada das interações entre a sociedade civil, a sociedade política e as polícias. Porto Alegre: Civitas v.8 n.3, 2008

Didático. UFF, 2004.

Polícia, controle social e democracia. In: Coletânea de Textos para Uso

Desplazamiento forzado en la Comuna 13: la huella invisible de la guerra. Informe Centro de Memoria Histórica. Bogotá: Editora Aguilar, Altea, Taurus, Algaguara, S.A, 2010. 
DONICCI, Virgílio Luiz. A criminalidade no Brasil: meio milênio de repressão. Rio de Janeiro: Editora Forense, 1984.

Ensayos críticos Plan Colombia. Facultad de Derecho, Ciencias Políticas y Sociales de la Universidad Nacional de Colombia. Disponível em http://www.urru.org/videosbolibananos/textos/Plan_Colombia_Ensayos_cr\%C3\%ADticos_U N.pdf

DURAND, Jorge. El oficio de investigar. Universidad de Guadalara, 2012. Disponível em http://mmp.opr.princeton.edu/JorgeDurand/PDF/Durand_El\%20oficio\%20de\%20investigar.p df

FERNANDES, Clemir. A esfinge da UPP e os oráculos da religião: Percepção de lideranças religiosas nativas sobre violência e Unidade de Polícia Pacificadora em favelas cariocas. Rio de Janeiro: ISER, 2013.

GOLDSTEIN, Herman. Policiando uma sociedade livre. Coleção Policia e Sociedade, vol. 9. São Paulo: EDUSP, 2003.

GONZÁLEZ, R. Respuestas a la violencia en perspectiva de seguridad ciudadana. Un estudio descriptivo de políticas de seguridad ciudadana. In: Drogas, policías y delincuencia: otras miradas a la seguridad ciudadana. CLACSO, 2015.

GREENE, Jack R. Administração do trabalho policial: questões e análises. Coleção Policia e Sociedade, vol. 5. São Paulo: EDUSP, 2000.

HOLANDA, Cristina Buarque. Polícia e direitos humanos. Rio de Janeiro: Editora Revan, 2005.

HOLlOWAY, Thomas H. Polícia no Rio de Janeiro: repressão e resistência numa cidade do século XIX. Rio de Janeiro: FGV, 1997.

INÉS, Blanca. El conflicto armado en la comuna 13: Obstáculos y posibilidades para la participación y el desarrollo organizativo. Revista Trabajo Social No. 6. Medellín, 2007.

KANT DE LIMA, Roberto. Direitos Civis, Estado de Direito e "Cultura Policial”: a formação policial em questão. In: Coletânea de Textos para Uso Didático. UFF, 2004.

KANT DE LIMA, Roberto; EILBAUM, Lucia; PIRES, Lenin. Conflitos, direitos e moralidades em perspectiva comparada. Rio de Janeiro: Garamond, 2010.

KANT DE LIMA, Roberto; MISSE, Michel; MIRANDA, Ana Paula M. Violência, Criminalidade, Segurança Pública e Justiça Criminal no Brasil: Uma Bibliografia. Rio de Janeiro: BIB, $\mathrm{n}^{\circ}$ 50/2, 2000.

LALANDA, Piedad. Sobre a metodologia qualitativa na pesquisa sociológica. Análise Social, vol. XXXIII (148), 1998 (4. $\left.{ }^{\circ}\right)$. 
LEAL, Ana Beatriz; PEREIRA, Ibis Silva; FILHO, Oswaldo Munteal. Sonho de uma polícia cidadã: Coronel Carlos Magno Nazareth Cerqueira. Rio de Janeiro: NIBRAHC, 2010.

MACHADO, Ana B. O Muro é a Notícia: o Discurso da Ordem e o Ecolimite do Santa Marta. Ana Brasil Machado. Rio de Janeiro: UFRJ, /PPG Universidade Federal do Rio de Janeiro: V. 1, N.2, 2011.

MACHADO DA SILVA, Luiz Antonio; LEITE, Marcia P. VIOLÊNCIA, CRIME E POLÍCIA: o que os favelados dizem quando falam desses temas?

Sociedade e Estado, v. 22, n. 3. Brasília,2007

MANING, Peter K. Police contingencies. University of Chicago Press. USA, 2003.

MENEZES, Palloma. Rumores e críticas em favelas pacificadas: um estudo sobre como moradores e policiais avaliam as Unidades de Polícia Pacificadora. Buenos Aires, CLACSO, 2013.

Disponível

em

http://biblioteca.clacso.edu.ar/clacso/becas/20131231022532/PolicyBrief.pdf

MINAYO, Maria Cecília S; SOUZA, Edinilsa Ramos. Estudo comparativo sobre riscos profissionais, segurança e saúde ocupacional dos policiais civis e militares do Estado do Rio de Janeiro. Relatório Final da Pesquisa da Senasp, 2005.

MINAYO, Maria Cecília de Souza; SOUZA, Edinilsa Ramos; CONSTANTINO, Patrícia, (Coord.). Missão prevenir e proteger: condições de vida, trabalho e saúde dos policiais militares do Rio de Janeiro. Rio de Janeiro: Editora Fiocruz, 2008.

MIRANDA, Ana Paula M. Militarização e direitos humanos: gramaticas em disputas nas políticas de segurança pública do Rio de Janeiro/Brasil, 2015. Disponível em http://sociologico.revues.org/

MISSE, Michel. Como desarmar a violência policial? Uma breve reflexão. In: Coletânea de Textos para Uso Didático. UFF, 2004.

MONET, Jean Claude. Polícias e sociedades na Europa. Coleção Policia e Sociedade, vol. 3. São Paulo: EDUSP, 2000.

MONJARDET, Dominique. O que faz a polícia: sociologia da força pública. Coleção Policia e Sociedade, vol.10. São Paulo: EDUSP, 2003.

MOURÃO, Barbara Musumeci. UPPs - Uma polícia de que gênero? Relatório parcial de pesquisa. Rio de Janeiro: CESEC, 2013.

MUNIZ, Jacqueline de Oliveira; ALBERNAZ, Elizabete. Moralidades entrecruzadas nas UPPs: uma narrativa policial. XI Reunião de Antropologia do Mercosul. Montevideo: 2015. Disponível

em:https://www.academia.edu/21459289/Moralidades_entrecruzadas_nas_UPPs_Uma_narrat iva_policial . Acesso em: 12 de março de 2016.

MUNIZ, Jacqueline de Oliveira; LARVIE, Sean Patrick; MUSUMECI, Leonarda; FREIRE, Bianca. Resistências e dificuldades de um programa de policiamento comunitário. Tempo 
Social; Rev. Social. USP, S. Paulo, 9(1): 197-213, maio de 1997. Disponível em: http://www.revistas.usp.br/ts/article/view/86552/89391 . Acesso em: 12 de maio de 2016.

MUNIZ, Jacqueline de Oliveira; MELLO, Kátia Sento Sé. Nem tão perto, nem tão longe: o dilema da construção da autoridade policial nas UPPs. Civitas, Porto Alegre, v.15, n. 1, p. 4465, jan./mar. 2015. Disponível em: http://revistaseletronicas.pucrs.br/ojs/index.php/civitas/article/view/19939/12832>. Acesso em: 12 de março de 2016.

MUNIZ, Jacqueline. Ser policial é sobretudo uma razão de ser: cultura e cotidiano da Polícia Militar do Estado do Rio de Janeiro. Tese de Doutorado. Instituto Universitário de Pesquisa do Rio de Janeiro, 1999.

MUNIZ, Jacqueline; PROENÇA JR., Domício; PONCIONI, Paula. Da governança de polícia à governança policial: controlar para saber, saber para governar. Versão resumida publicada na Revista Brasileira, ano 3, ed. 5, 2009. Disponível em: < www.forumseguranca.org.br>. Acesso em 23 de julho de 2015.

MUNIZ, Jacqueline; PROENÇA JUNIOR, Domício. Forças armadas e policiamento. Revista Brasileira de Segurança Pública, ano 1, ed. 1, 2007.

Bases conceituais de métricas e padrões de medida de desempenho policial. In: CARUSO, Haydée; MUNIZ, Jacqueline; BLANCO, Antonio Carlos Carballo, (Org.). Polícia, Estado e sociedade: prática e saberes latino-americanos. Rio de Janeiro, 2007.

Da accountability seletiva à plena responsabilidade policial. In: CARUSO, Haydée; MUNIZ, Jacqueline; BLANCO, Antonio Carlos Carballo (Org.). Polícia, Estado e sociedade: prática e saberes latino-americanos. Rio de Janeiro, 2007.

; __. Muita politicagem, pouca política os problemas da polícia são. Estudos Avançados, set./dez. 2007, v. 21, n. 61, p.159-172. ISSN 0103-4014.

Janeiro, 2006.

. Os rumos da construção da polícia democrática. Boletim IBCCRIM, n. 164, Rio de

NASCIMENTO, Nívio C. Entre as leis e o mundo: polícia e administração de conflitos numa perspectiva comparativa. Tese de doutorado. Brasília, 2003.

NOVIÓN, Martin-Léon-Jacques I. Las Últimas Fronteras del Sistema Capitalista:

Hegemonía, Integración Económica y Seguridad en las Américas. La Amazonía y el futuro en cuestión. Tese de doutorado. Universidad Nacional Autónoma de México, 2009

NÚCLEO DE ESTUDOS DA VIOLÊNCIA DA UNIVERSIDADE DE SÃO PAULO. Manual de Policiamento Comunitário: Polícia e Comunidade na construção da Segurança. São Paulo: NEV/USP, $2009 . \quad$ Disponível em: http://www.snh2013.anpuh.org/resources/anais/27/1364748002_ARQUIVO_TEXTOBrunoM arquesSilvaANPUH2013.pdf . Acesso em 13 de novembro de 2015. 
OLIVEIRA, João P. Pacificação e tutela militar na gestão de populações e territórios. MANA 20(1), 2014.

O Mercado Sobe o Morro. A Cidadania Desce? Estudo Sobre os Efeitos da Pacificação no Santa Marta. FGV. Disponível em http://peep.ebape.fgv.br/sites/peep.ebape.fgv.br/files/O_Mercado_Sobe_o_Morro_A_Cidadan ia_Desce_Estudo_Sobre_os_Efeitos_da_Pacificacao_no_Santa_Marta.pdf

PONCIONI, Paula. Tornar-se policial: a construção da identidade profissional do policial no Estado do Rio de Janeiro. Tese (Doutorado em Sociologia) - Universidade de São Paulo, 2003.

. O profissionalismo na formação profissional do policial brasileiro: rupturas, permanências e desdobramentos contemporâneos. Brasília: Segurança, Justiça e Cidadania / Ministério da Justiça, Secretaria Nacional de Segurança Pública (SENASP) - Ano 4, n. 7, 2014.

PORTO, Maria Stella Grossi; COSTA, Arthur Trindade Maranhão. Condutas Policiais e Códigos de Deontologias: o controle da atividade policial no Brasil e no Canadá. Brasília: Editora da Universidade de Brasília, 2014.

RAGIN, Charles, C. La construcción de la investigación social. Universidad de los Andes, 2007

REINER, Robert. A política da polícia. Coleção Polícia e Sociedade, vol.11. São Paulo: EDUSP, 2003.

RIBEIRO, Ludmila. O nascimento da polícia moderna: uma análise dos programas de policiamento comunitário implementados na cidade do Rio de Janeiro (1983-2012). Análise Social, 211, XLIX (2. $\left.{ }^{\circ}\right), \quad$ p. 272-309, 2014. Disponível em: http://analisesocial.ics.ul.pt/documentos/AS_211_a03.pdf . Acesso em 12 de março de 2016.

ROCHA, Luiz Carlos. Organização policial brasileira. São Paulo: Saraiva, 1991.

ROLIM, Marcos. A síndrome da rainha vermelha: policiamento e segurança pública no século XXI. Rio de Janeiro: Zahar, 2009.

SECRETARIA DE ESTADO DE SEGURANÇA (RJ). Currículos para os Cursos de Formação: Soldados - Cabos - Sargentos. Rio de Janeiro: Secretaria de Segurança, 2012.

. Demonstrativo Mensal das Incidências Criminais - UPP Santa Marta. Rio de Janeiro: NuPESP/ISP, 2007/2015. Disponível em: http://www.isp.rj.gov.br/Conteudo.asp?ident=61 . Acesso em: 13 de novembro de 2015.

SENTO-SÉ, João Trajano. Criminalidade, violência e imagens no Rio de Janeiro. In: BIRMAN, P.; NOVAES, R.; CRESPO, S. (Org.). O mal à brasileira. Rio de Janeiro: EdUERJ, 1997.

Imagens da ordem, vertigens do caos: o debate sobre as políticas de segurança pública no Rio de Janeiro, nos anos 80 e 90. In: Crime organizado e política de segurança pública no rio de janeiro. Arché Interdisciplinar, ano 7, n. 19. Rio de Janeiro: Universidade Cândido Mendes, 1998. 
Prevenção ao crime e teoria social. In.: Nova e antigas questões. Lua Nova - Revista de Cultura e Política, São Paulo, $\mathrm{n}^{\circ}$ 83, pp. 9-40, 2011. Disponível em: http://www.cedec.org.br/files_pdf/luanova/LN-83.pdf . Acesso em 13 de novembro de 2015.

SILVA, Alexandra Valéria Vicente. A polícia militar e a sociedade na representação social dos policiais militares do Rio de Janeiro. Dissertação (Mestrado em Psicologia Social) - Universidade Estadual do Rio de Janeiro, 2006.

SILVA, Bruno Marques, A Polícia é o público e o público é a Polícia: o policiamento comunitário e a política de segurança brizolista no Rio de Janeiro (1983-1994). XXVII Simpósio Nacional de História. Conhecimento histórico e diálogo social. Natal: ANPUH, 2013. Disponível em: http://www.snh2013.anpuh.org/resources/anais/27/1364748002_ARQUIVO_TEXTOBrunoM arquesSilvaANPUH2013.pdf . Acesso em 13 de novembro de 2015.

SILVA, Flavia D; CARVALHO, Fernanda C; CAVALCANTE, Lívia R. O programa UPP na comunidade Santa Marta, Rio de Janeiro, e a dimensão da inclusão socioespacial. Disponível em http://unuhospedagem.com.br/revista/rbeur/index.php/anais/article/viewFile/4254/4124

SILVA, Jacqueline S. Manutenção da ordem pública e garantia dos direitos individuais: os desafios da polícia em sociedades democráticas. Revista Brasileira de Segurança Pública, Ano 5 Edição 8 Fev/Mar. São Paulo: 2011

SILVA, Jailson S.; BARBOSA, Jorge. Favela: alegria e dor na cidade. Rio de Janeiro: Senac Rio, 2005.

SILVA, Jorge. Controle da criminalidade e segurança pública: na nova ordem constitucional. Rio de Janeiro: Editora Forense, 1999.

SILVA, Laerte C. Ecolimite e contenção de favela: o caso do muro da favela Santa Marta. Anais XVI ENANPUR. Belo Horizonte, 2015.

SKOLNICK, Jerome H. Justice without Trial: law enforcement in democratic society. United States: Macmillian College Company, Inc. 1994.

SKOLNICK, Jerome H.; BAYLEY, David H. Policiamento Comunitário: questões e práticas através do mundo. Coleção Policia e Sociedade, vol. 6. São Paulo: EDUSP, 2001.

SOARES, Barbara Musumeci. Unidade de Polícia Pacificadora: o que pensam os policiais. Rio de Janeiro: CESEC, 2012.

SOARES, Gláucio A. D. Covariatas estruturais. Não matarás: Rio de Janeiro: FGV, 2008.

SOARES, Luiz Eduardo; BATISTA, André; PIMENTEL, Rodrigo. Elite da tropa. Rio de Janeiro: Editora Objetiva, 2006.

Tendencias Globales Desplazamiento Forzado en 2015: Forzados a Huir. Relatório ACNUR 2015 . 
TAYLOR, Charles. Argumentos filosóficos. São Paulo: Edições Loyola, 2000.

TONRY, Michael; MORRIS, Norval. Policiamento moderno. Coleção Polícia e Sociedade, vol.

7. São Paulo: EDUSP, 2001.

TORO, Natalia, Q; ECHEVERRI, Jacobo C; GIL, Herman M. Memoria cultural Comuna 13. Universidad de Antioquia, Medellín. Disponível em http://iep.udea.edu.co:8180/ADcomuna13/bitstream/123456789/49/1/Quiceno_etal.pdf

TROJANOWICZ, Robert. Communit Policing is not Police-Community Relations. In.: FBI Law Enforcement Bulletin, Washington-DC, v. 59, nº 10, pp. 6-11, October 1990.

Community policing and the challenge of diversity. National Center for Community Policing. School of Criminal Justice. Michigan State University. Michigan: 1991.

TROJANOWICZ, Robert; BUCQUEROUX, Bonnie. Community Policing: how to get started. $2^{\mathrm{a}}$ ed. Cincinnati, OH: ELSEVIER, 1998.

TROJANOWICZ, Robert; MOORE, Mark H. Corporate Strategies for Policing. In.: Perspectives on Policing. U. S. Department of Justice. National Institute of Justice. Washington-DC, 1988.

VELÁSQUEZ, Alejo V; PINZÓN, Viviane G. Seguridad ciudadana y gasto público: reflexiones sobre el caso colombiano. Universidad Nacional de Colombia, 2008.

VELÁSQUEZ, Hugo A. Os governos locais e a segurança cidadã. Disponível em http://www.rolim.com.br/2002/_pdfs/seg_Hugo_Acero.pdf

$\overline{\text { mirada }} ;-\begin{gathered}\text { Reforma policial y uso legítimo de la fuerza en un Estado de derecho: una } \\ \text { la }\end{gathered}$ experiencia de $\quad$ Colombia. Disponível em http://www.comunidadesegura.org.br/files/reformapolicialyusolrgitimodela.pdf 


\section{ANEXO I - ROTEIROS DE ENTREVISTAS}

\section{GuíA SEMIESTRUCTURADA - NivEl EJECUTIVo}

\section{IDENTIFICACIÓN}

○ Edad:

- Profesión:

- Grado de estudio:

- Tiempo de trabajo en la PONAL:

- Función actual:

o Tiempo de trabajo en la función:

\section{INTRODUCCIÓN}

1. Cuál fue su motivación para ingresar en la Policía?

2. Que es ser policía para ti?

3. Te sientes satisfecho de su trabajo? Te parece que hiciste una buena elección? Por qué?

4. Cómo es la relación con sus colegas superiores? Y los de igual grado?

5. Cuáles son las características de la situación de seguridad de Medellín? Y en la Comuna $13 ?$

\section{Que hace la Policía}

6. Que hace la policía, o sea, que tipo de situaciones la policía es llamada a actuar (quehacer de policía)?

7. Hay casos que no deberían ser atendidos por la policía, o sea, que no son trabajo de policía? Ejemplo.

8. Qué hace una patrulla? Cuáles son los grados de policías que hacen la patrulla?

9. Cuál es tu función en la patrulla?

10. Cuéntame que haces en tu rutina de trabajo desde que se inicia su turno?

11. Qué casos son más frecuentes?

12. Qué te parece el programa CI2? Cuáles son los retos del programa?

13. Cuál es el rol de la policía en este programa?

\section{COMO LO HACE}

14. Cuéntame un caso? 
15. Que te llevó a actuar de ese modo? (documentos institucionales, entrenamientos, experiencia, ejemplo de colegas...)

16. Dime cuales son las dificultades para ejercer tu trabajo? Y ventajas?

\section{ROTEIRO SEMIESTRUTURADO PARA POLICIAIS}

\section{IDENTIFICAÇÃO}

○ Nome:

○ Idade:

- Profissão:

○ Formação:

- Instituição que trabalha: PMERJ

- Tempo de trabalho na corporação:

- Função atual:

- Tempo de trabalho na função atual:

\section{INTRODUÇÃO}

1. Qual foi sua motivação para ingressar na polícia?

2. Que é ser policial para você?

3. Você se sente satisfeito com sua escolha profissional? A escolheria novamente?

4. Como é a relação hierárquica com seus superiores? E com os colegas de igual posição hierárquica?

5. Como está a situação de segurança pública no Rio de Janeiro? E no Santa Marta? Qual o perfil da comunidade local?

\section{UPP}

6. Como funciona a UPP Santa Marta em termos operacionais, planejamento, metas/objetivos, tipos de atividades, armamento, escala de trabalho, relação com comunidade?

7. Como os policiais são selecionados para trabalhar na UPP? Há um programa específico de formação?

\section{O QUE FAZ O POLICIAL NA UPP}

8. Como é sua rotina de trabalho quando inicia seu plantão?

9. Como é sua escala de trabalho?

10. Quais atividades você desempenha em seu dia-a-dia de trabalho? 
11. Que tipos de casos a polícia atende no Santa Marta?

12. Há situações que não são caso de polícia?

13. Quais são os casos mais frequentes?

14. O que acha da UPP?

\section{COMO FAZ}

15. Conte-me um caso que tenhas atendido?

16. O que te levou a agir dessa maneira? (documentos, manuais, treinamento, experiência prática nas ruas, orientações, aprendizagem com colegas, diretrizes) .

17. Quais as principais dificuldades para realizar seu trabalho?

18. O que mudaria se pudesse na UPP? 
ANEXO II - Programa CI2

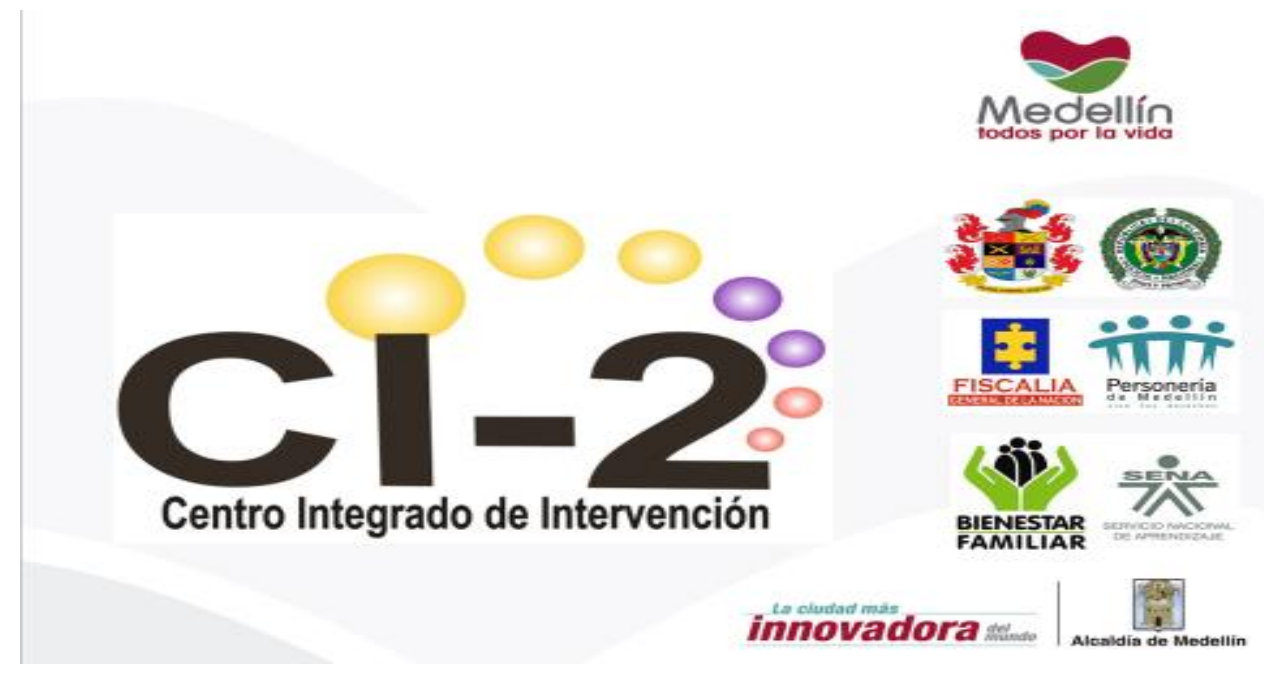

\section{Centro Integrado de Intervención}

Medellín

Tuvo Origen el 14 de Agosto de 2010 de un CONSEJO METROPOLITANO DE SEGURIDAD, y nace bajo la premisa de armonizar las instituciones del Estado, en la mejora de la convivencia y seguridad de los habitantes de la Comuna 13.

- COMBATIR, DESARTICULAR Y AFECTAR las estructuras ciminales que wineran los derechos y libertades de las habitantes de la Comuna XII y que confrontan a las autoridades legamerte constituidas

- GARANTIZAR el ejercicio y goce de los derechos fundamentalas, económicos, sociales, cuturales y colectios de las habitantes de la Comuna 13

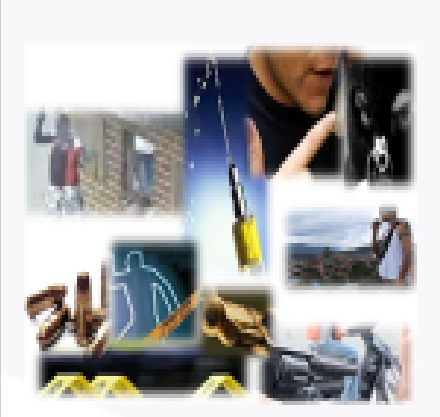

PRINCIPALES PROBLEMAS QUE SE PRESENTAN.-

- Homicidios, Lesiones Personales

- Extorsiones, Pago de Vacunas

- Desplazamiento Fonado e hraurbano

- Confrontaciones entre Grupos Delincuenciales

- Problemas Sociales Surgidos de la Prolferación De manden Barrios Subnormales

- Herencia de Narcotrafico, Guarila y Autodefensas

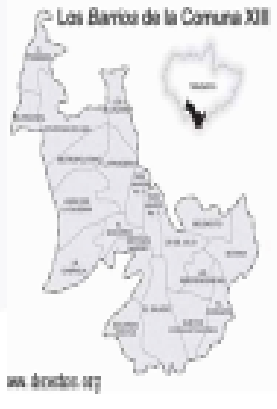


Componentes Centro Integrado de Intervención

Medellín

todos por la vida

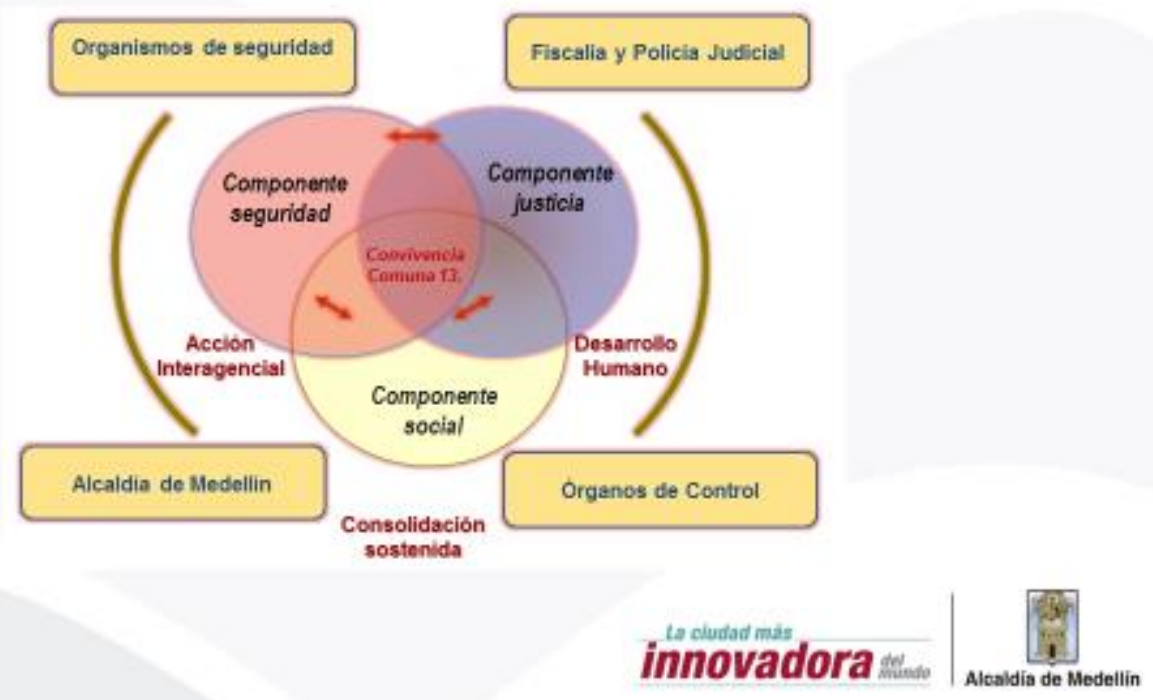

Componentes Centro Integrado de Intervención

Medellín

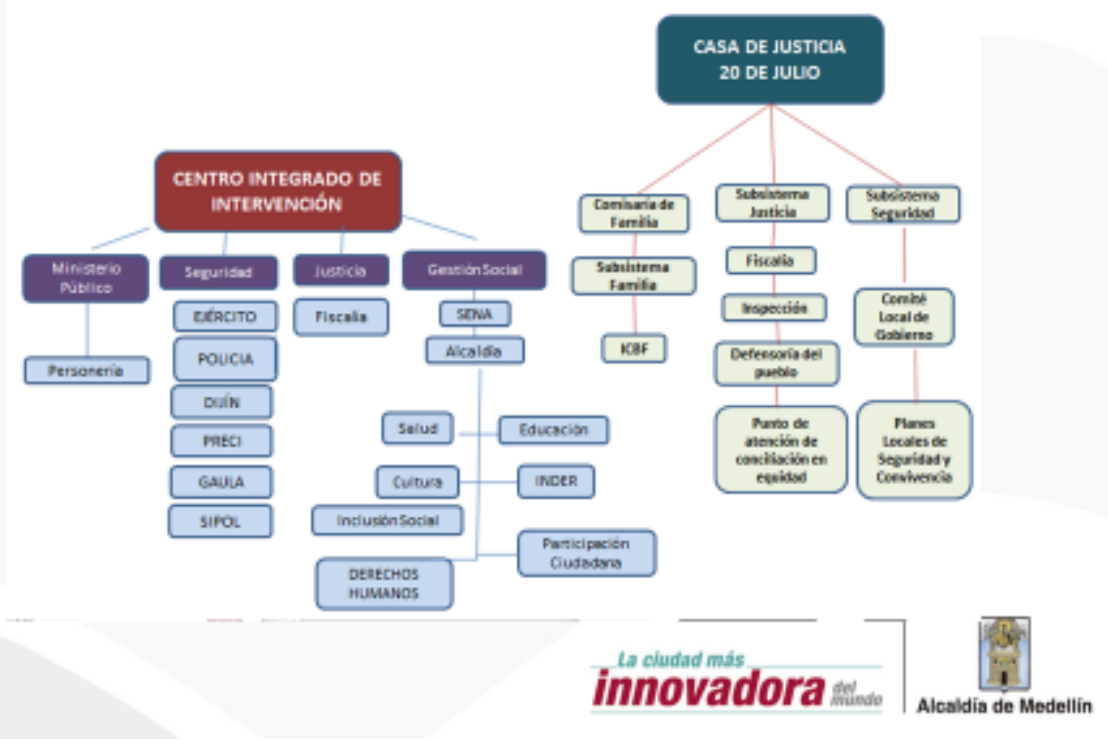




\section{Situación actual Cl-2 Comuna 13}

Medellín

todos por la vida
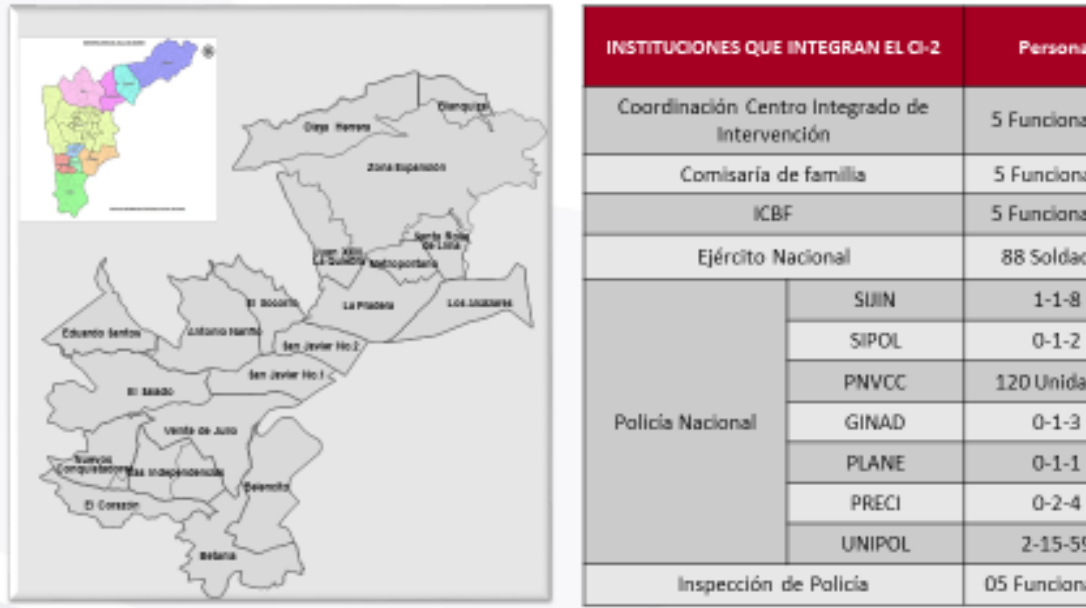

\begin{tabular}{|c|c|c|}
\hline \multicolumn{2}{|c|}{$\begin{array}{c}\text { Coardinacián Centra Integrado de } \\
\text { Intervención }\end{array}$} & 5 Funcianarias \\
\hline \multicolumn{2}{|c|}{ Comisaría de farnills } & 5 Funclanarias \\
\hline \multicolumn{2}{|c|}{ ICBF } & 5 Funcianarias \\
\hline \multicolumn{2}{|c|}{ Ejército Nacional } & 88 soldados \\
\hline \multirow{7}{*}{ Policis Nacianal } & SIIIN & $1-1-8$ \\
\hline & SIPOL & $0-1-2$ \\
\hline & PNVCC & 120 Unidades \\
\hline & GINAD & $0-1-3$ \\
\hline & PLANE & $0-1-1$ \\
\hline & PRECI & $0-2-4$ \\
\hline & UNIPOL & $2-15-59$ \\
\hline \multicolumn{2}{|c|}{ Inspección de Palicis } & 05 Fundianarias \\
\hline
\end{tabular}

La ciudad más

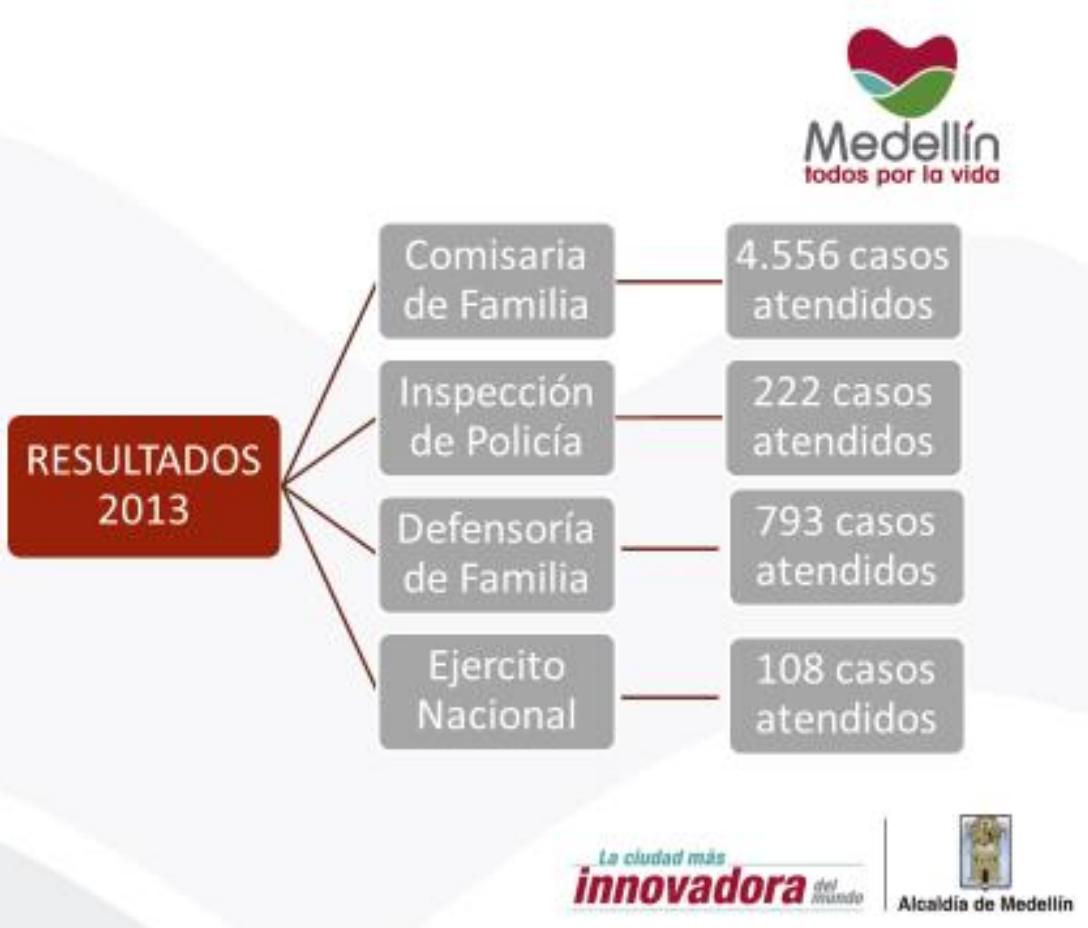




\section{Componente social:}

Medellín

odos por la vida

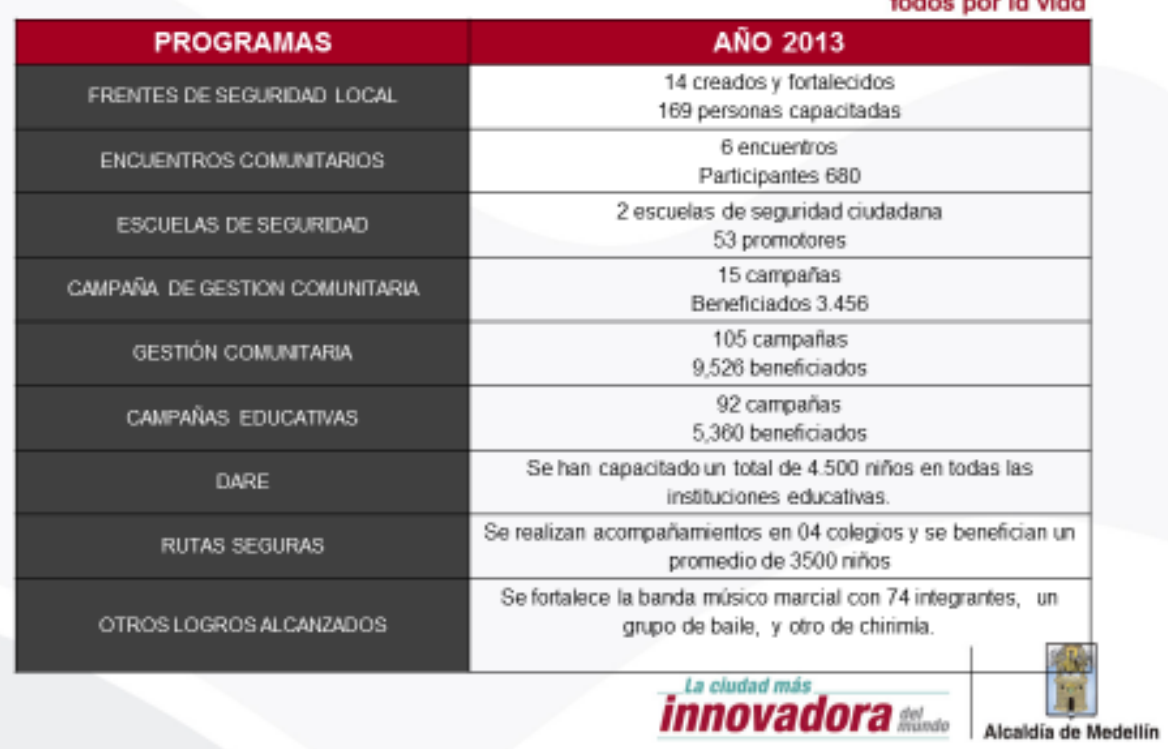

\section{Intervenciones Sociales Centro Integrado de Intervención Comuna 13}

\section{Medellín}

\begin{tabular}{|c|c|}
\hline FERIA DE SERVICIOS & BARRIOS Y SECTORES \\
\hline CENTRO NTEGRADO OE NTEFNENCION CH-2 & $\begin{array}{l}\text { - El Refugio } \\
\text { - Juan XXill, sector las Pilanas } \\
\text { - Blanquizal } \\
\text { - Belencita Corazón } \\
\text { - Eduardo Santos } \\
\text { - Altos de la Virgan } \\
\text { - La Gabriela }\end{array}$ \\
\hline
\end{tabular}

\begin{tabular}{|c|c|}
\hline $\begin{array}{l}\text { VACACIONES POR LA VIDA, LA } \\
\text { SEGURIDAD Y LA CONVIVENCIA }\end{array}$ & BARRIOS Y SECTORES \\
\hline CENTRO NIEGRADO DE NTERVENCION CL-2 & $\begin{array}{l}\text { - San Cristabal, Sector la Loma } \\
\text { - Belén, sector Buena Vista } \\
\text { - Robleda, Kernedy sector la Susarita } \\
\text { - San Javier, ndependencias } \\
\text { - San Antorio de Prado, sector Limonar } 1 \\
\text { - San Javier, sector la Asamadera }\end{array}$ \\
\hline
\end{tabular}

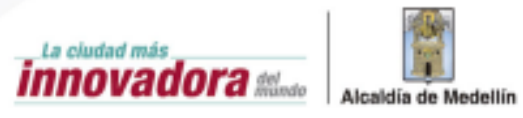




\section{Intervenciones Sociales Centro Integrado de Intervención Comuna 13}

\begin{tabular}{|c|c|}
\hline FERIA DE SERVICIOS & BARRIOS Y SECTORES \\
\hline CENTRO NTEGRAOO DE NTEFNENCION CH-2 & $\begin{array}{l}\text { - El Refugio } \\
\text { - Juan XXII, sector las Pilonas } \\
\text { - Blanquizal } \\
\text { - Belencito Corazón } \\
\text { - Eduardo Sartos } \\
\text { - Altos de la Virgen } \\
\text { - La Gabriela }\end{array}$ \\
\hline
\end{tabular}

Vacaciones por la Vida, la Seguridady la Convivencia

\begin{tabular}{|c|c|}
\hline $\begin{array}{l}\text { VACACIONES POR LA VIDA, LA } \\
\text { SEGURIDAD Y LA CONVIVENCIA }\end{array}$ & BARRIOS Y SECTORES \\
\hline CENTRO NTEGRADO DE NTERNENCION CL-2 & $\begin{array}{l}\text { - San Cristóbal, Sector la Loma } \\
\text { - Belén, sector Buena Vista } \\
\text { - Robledo, Kennedy sector la Susanita } \\
\text { - San Javier, Independencias } \\
\text { - San Artonio da Prado, sector Limonar } 1 \\
\text { - San Javier, sector la Asomadera }\end{array}$ \\
\hline
\end{tabular}

Temas Tratados: camparia anti-extrosión, protecoion a esceranios deportovos, Vacunación Simbólica, Buen uso del 123

\begin{tabular}{|c|c|}
\hline $\begin{array}{l}\text { NAVIDAD PARA PRESERVAR LA } \\
\text { VIDA }\end{array}$ & BARRIOS Y SECTORES \\
\hline CENTRO INTEGRADO DE INTERVENCION Cl-2 & $\begin{array}{l}\text { - Comuna } 13 \text { Nuevos Conquistadores, } \\
\text { sectar Zonitas } \\
\text { - Comuna } 3 \text { sector el Pomar } \\
\text { - Comuna } 5 \text { Cancha Rene Higuita } \\
\text { - Comuna } 6 \text { Cancha Polidaportiva } 12 \\
\text { - Comuna } 8 \text { sector las Estancias } \\
\text { - Comuna } 15 \text { sector el Bob (Colinita) } \\
\text { - Covero Occidante, la Aurora } \\
\text { - Comuna } 10 \text { Parque San Antorio } \\
\text { - Comuna } 1 \text { Santo Domingo parte Baja }\end{array}$ \\
\hline
\end{tabular}

Temas Tratados: Póchora, Makrato Ifantil, Autocuidado, Firnas. Consumo de Licoc, Volumen Alto, Porte de armas, Balas Perdidas, Hurto de Vivenda

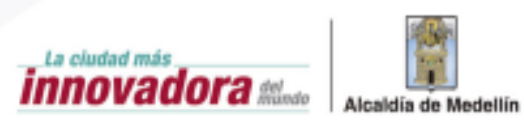


Metas Centro Integrado de Intervención 2014

Medellín

todos por la vida

\begin{tabular}{|c|c|}
\hline & METAS \\
\hline CENTRO INTEGRADO DE INTERVENCION Cl-2 & $\begin{array}{l}\text { - Homicidios } \\
\text { - Rentas Crimingles } \\
\text { - Vialencia Intrafamiliar } \\
\text { - Desplazamiento Forzado } \\
\text { - Perdida de legitimidad de las instituciones del estado y } \\
\text { de la fuerza pública. } \\
\text { - Afianzamiento y sostenibilidad en el tiempo de las } \\
\text { estructuras criminales, Persistencia de la Violencia } \\
\text { Criminal, Rentas criminales (tráfico de estupefacientes y } \\
\text { extorsión) } \\
\text { Continúo uso de Nifios, Niñas, adolescentes y Jóvenes } \\
\text { por parte de las estructuras criminales para la comisión } \\
\text { de delinos }\end{array}$ \\
\hline
\end{tabular}

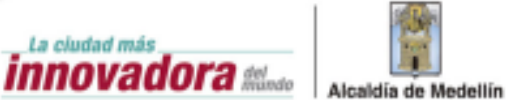




\section{ANEXO III - Programa de Formación de Patrulleros}

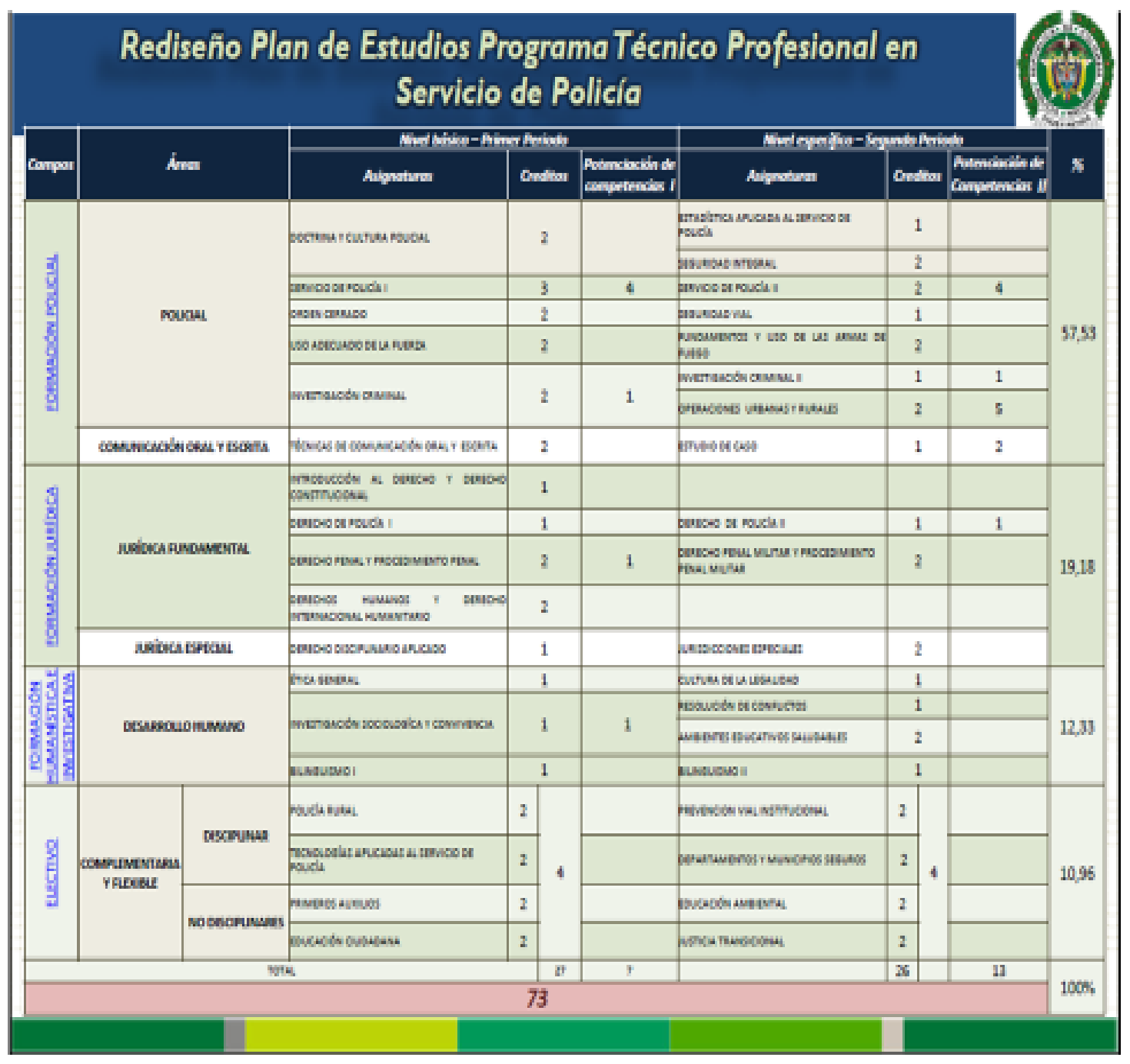

